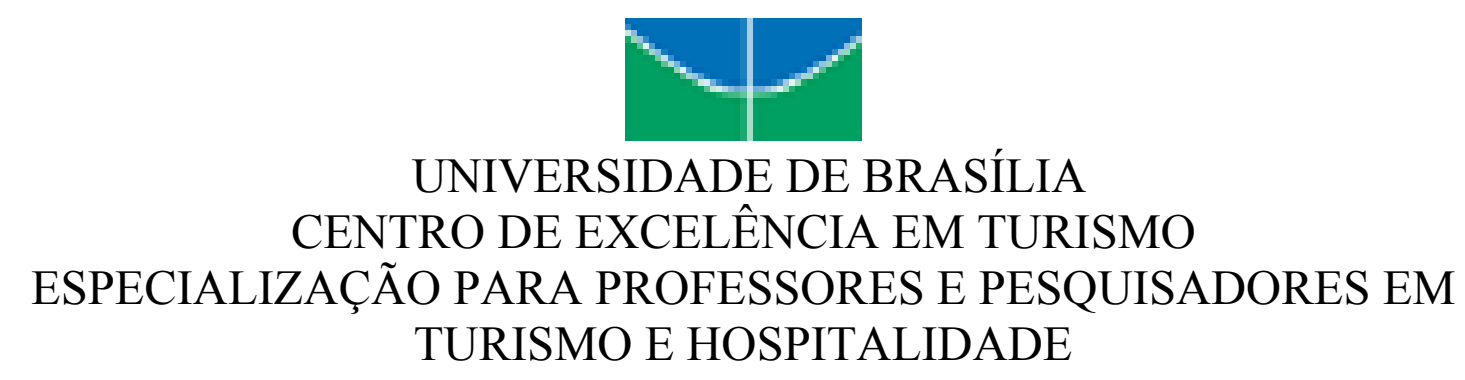

\title{
A MAGIA DOS LENÇÓIS MARANHENSES UMA CONTRIBUIÇÃO PARA O TURISMO SUSTENTÁVEL
}

\author{
GERSON CARVALHO
}

\section{Prof $^{\mathrm{a}}$ Dr $^{\mathrm{a}}$ MARIA SALETE KERN MACHADO \\ Orientadora}

Monografia apresentada ao Centro de Excelência em turismo da Universidade de Brasília como requisito parcial para a obtenção do certificado de Especialista em Turismo e Hospitalidade.

Brasília, DF, janeiro - 2004. 
UNIVERSIDADE DE BRASÍLIA

Centro de Excelência e Turismo

Curso de Especialização para Professores e Pesquisadores em Turismo e Hospitalidade

\title{
A MAGIA DOS LENÇÓIS MARANHENSES - UMA CONTRIBUIÇÃO PARA O TURISMO SUSTENTÁVEL
}

\author{
GERSON CARVALHO
}

BANCA EXAMINADORA

\author{
Prof $^{\mathrm{a}} \mathrm{Dr}^{\mathrm{a}}$ Maria Salete Kern Machado \\ Orientadora
}

Prof $^{\circ}$ Dr Rafael Sânzio Araújo dos Anjos

Brasília, DF, 


\section{RESUMO}

Esta monografia tem como foco principal o desenvolvimento do Turismo nos Lençóis Maranhenses, os impactos socioeconômicos e ambientais provocados pelas atividades turísticas, as políticas do município de Barreirinhas, portal dos Lençóis Maranhenses, para o Turismo no local e as principais atrações turísticas dessa destinação que deu um novo impulso ao turismo no Maranhão.

Por meio de pesquisa bibliográfica assim como de pesquisa de campo, foram coletados importantes dados em trabalhos realizados enfocando as atividades turísticas no local, como também junto aos moradores da região dos Lençóis, onde se procurou atingir todos os segmentos da sociedade, desde autoridades, comerciantes, antigos moradores e o turista, objetivando saber se os serviços oferecidos estavam de acordo com a expectativa dos turistas e se o turismo nos Lençóis Maranhenses está sendo praticado de acordo com os princípios da sustentabilidade. A contribuição desta pesquisa está nas considerações finais, com ênfase na Educação Ambiental.

PALAVRAS-CHAVE: Turismo Sustentável, Lençóis Maranhenses, Barreirinhas, Educação Ambiental. 


\section{AGRADECIMENTOS}

A Deus por ter preservado a minha saúde e pela sua proteção em todos os momentos da minha vida;

Ao SENAC, por meio do professor Luís Otávio, - Diretor Regional, pelo incentivo e custeio total do meu curso;

Aos professores da UNB/CET, pela dedicação, amizade e pelos valiosos conhecimentos passados para a nossa turma;

Às professoras Núbia e Tânia, e demais funcionários do CET, por todo o apoio que nos deram durante essa jornada;

Aos colegas de turma que tanto contribuíram com seus conhecimentos e acima de tudo com o carinho e amizade;

Às colegas de turma e de trabalho, Fernanda e Amélia, pela nossa amizade e por todos os trabalhos de grupo que fizemos com tanta dedicação.

À professora Salete, - minha orientadora, por toda a sua paciência, por nossos encontros e desencontros e por tudo que me ensinou na construção desta monografia.

Aos meus amigos e colabores de Barreirinhas: Ronildo, Fred, Ribinha e Guilherme. 
Dedico este trabalho à minha esposa Neurene, aos meus filhos Rodrigo e Vinícius, por terem acreditado na minha capacidade de realizar mais esta importante etapa da minha vida profissional.

In memoriam aos meus pais João Marcos e Belcina Carvalho, por tudo que me ensinaram, especialmente a acreditar que nada é impossível, quando se tem um sonho. 


\section{SUMÁRIO}

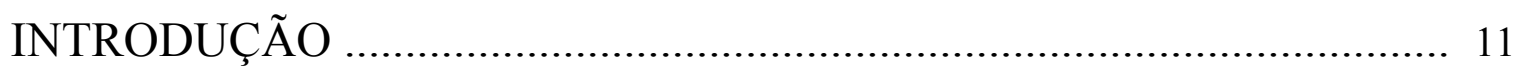

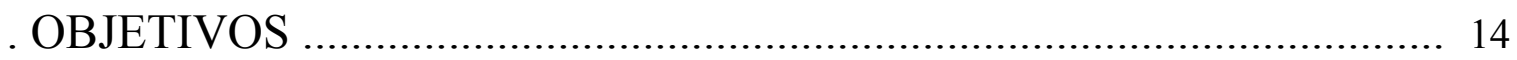

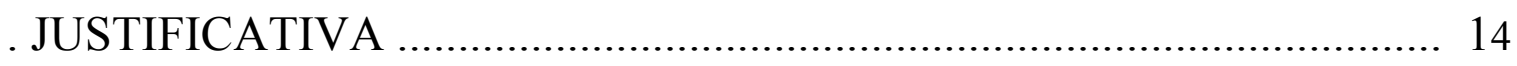

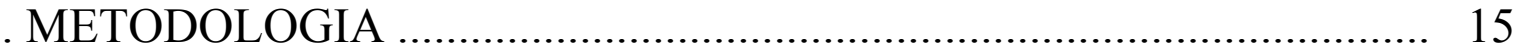

\section{CAPÍTULO 1:}

1.1- Análise do desenvolvimento do Turismo no Brasil no período de:

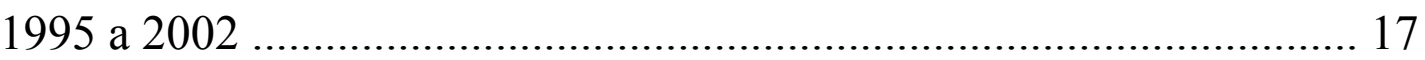

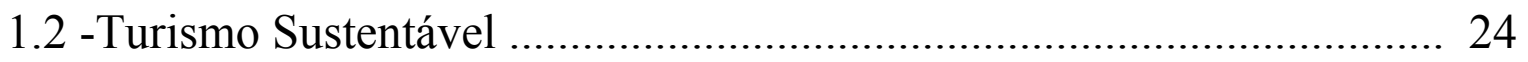

1.3 -Impactos do Turismo sobre o Meio Ambiente ……………................ 25

1.4 -Turismo e Imagem ...................................................................... 30

1.5 - Turismo no Maranhão ……………………................................. 31

CAPÍTULO 2:

2.1 - Lençóis Maranhenses ...................................................................... 34

2.2 - Como chegar aos Lençóis Maranhenses ......................................... 36

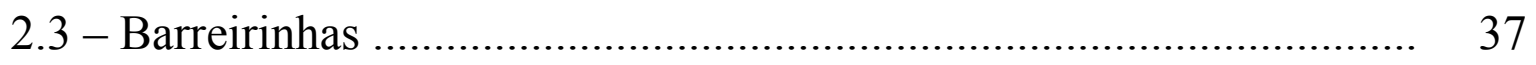

2.4 - Rio Preguiças ................................................................................. 39

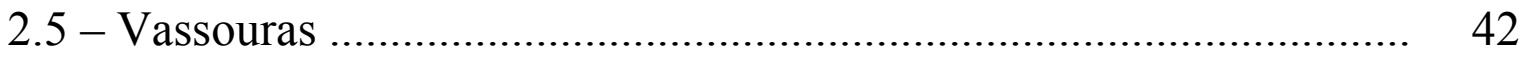

2.6 - Farol Mandacaru ..................................................................... 43

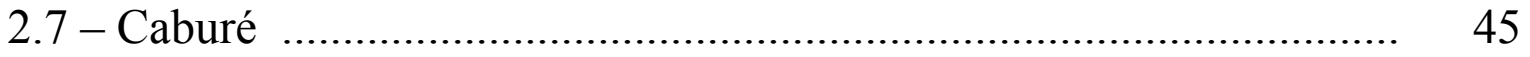

2.8 - As lagoas dos Grandes Lençóis ........................................................ 47

2.8.1 - Lagoa Azul ................................................................... 50

2.8.2 - Lagoa da Lua ……………..................................................... 51

2.8.3 - Lagoa do Peixe ................................................................. 52

2.9 - Características do Parque Nacional dos Lençóis Maranhenses ....... 54 
CAPÍTULO 3 - Turismo nos Lençóis Maranhenses e seus atores ......... 60

3.1 - Entrevista com Autoridades de Barreirinhas ................................... 60

3.2 Entrevista com moradores, donos de pousadas e agências de Turismo. 63 3.3 - Entrevista com o Turista ............................................................... 70

3.4 - Análise das Entrevistas: ............................................................ 74

3.4.1 - Com Autoridades; …………..........................................

3.4.2 - Com moradores, donos de pousadas e agências de Turismo; ...... 75

3.4.3 - Com o Turista. .........................................................................

CONSIDERAÇÕES FINAIS ........................................................... 83

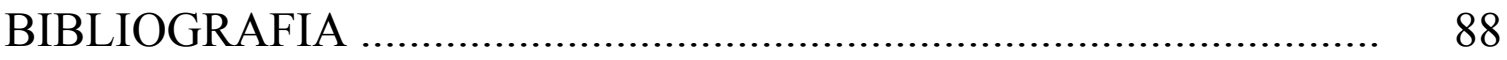

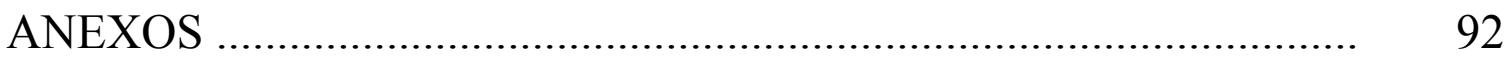

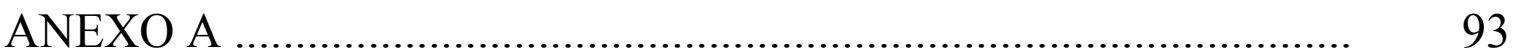

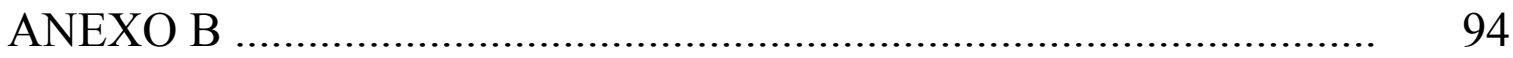




\section{LISTA DE ILUSTRAÇÕES}

Figura 1 - Morrarias - Grandes Lençóis

Figura 2 - Grandes Lençóis - por do sol

35

Figura 3 - MA 402 - Estrada Rosário - Barreirinhas 36

Figura 4 - Duna do Morro da Ladeira - entrada de Barreirinhas

Figura 5 - Rio Preguiças

Figura 6 - Preguiças, manguezais e guarás

Figura 7 - Entrada de Vassouras

Figura 8 - Dunas em Vassouras - Pequenos Lençóis

Figura 9 - Farol de Mandacaru

Figura 10 - Vila de Mandacaru - vista panorâmica

Figura 11 - Caburé

Figura 12 - Foz do Rio Preguiças, entre Atins e Caburé

Figura 13 - Toyota $4 \times 4$ 
Figura 16 - Lagoa Azul ...................................................................... 50

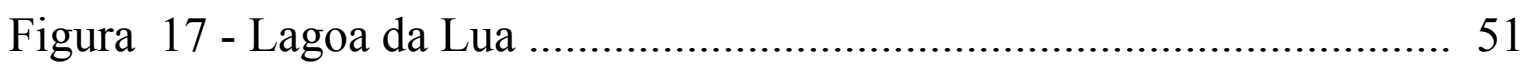

Figura 18 - Lagoa do Peixe …..................................................... 52

Figura 19 - Grandes Lençóis - Um Mundo Mágico …….............................. 53

Figura 20 - Mapa dos Grandes Lençóis ................................................. 54 


\section{LISTA DE TABELAS}

Tabela 1 - Residência permanente do turista 70

Tabela 2 - Motivo da viagem 70

Tabela 3 - Tempo de permanência no local 71

Tabela 4 - Tipo de transporte utilizado na viagem 71

Tabela 5 - Expectativas antes de chegar aos Lençóis Maranhenses 71

Tabela 6 - Avaliação da Destinação Turística 72

Tabela 7 - Avaliação dos serviços turísticos 72

Tabela 8 - Tipo de hospedagem utilizada nos Lençóis Maranhenses ...... 72

Tabela 9 - Visitou outros lugares antes de chegar ao PNLM? 73

Tabela 10 - Recebeu orientação sobre Preservação Ambiental no PNLM? 73

Tabela 11 - De quem é a responsabilidade pela Preservação Ambiental no PNLM?

Tabela 12 - Qual a importância da preservação da cultura local?. 


\title{
INTRODUÇÃO
}

\begin{abstract}
"O Turismo é uma Universidade em que o aluno nunca se gradua, é um Templo onde o suplicante cultua, mas nunca vislumbra a imagem de sua veneração, é uma viagem com destino sempre à frente, mas jamais atingido. Haverá sempre discípulos, sempre contempladores, sempre errantes aventureiros."
\end{abstract}

Lorde Curzon (1859 - 1925)

Governador-geral da Índia

O Turismo é uma das áreas da economia que mais cresce no mundo. De acordo com a Organização Mundial do Turismo - OMT, as previsões para os próximos dez anos são de um crescimento desigual entre os países, mas constante em todas as regiões, com uma forte tendência de um crescimento maior do turismo interno, nos países em desenvolvimento localizados nos continentes asiático, latino-americano e médio oriental.

No Brasil, segundo a Embratur (Instituto Brasileiro do Turismo), a atividade turística a partir de 1995 sofreu uma verdadeira revolução, acompanhando as tendências do mercado internacional.

A indústria do Turismo, nas últimas décadas, passou a ser o grande negócio da maioria dos países do mundo, especialmente para aqueles em fase de desenvolvimento e com grandes belezas naturais como é o caso do Brasil.

O Turismo no Brasil passou a impulsionar a economia, gerando renda, impostos e milhares de empregos em todas as suas regiões, especialmente na Amazônia, com sua admirada biodiversidade, maior floresta tropical do mundo, com a maior concentração de rios de água doce e volume de água do planeta; no Centro-Oeste que possui o fabuloso Pantanal Matogrossense, com sua incomparável concentração de aves, peixes e répteis e 
no Nordeste, onde estão concentrados os principais pólos turísticos do país, tais como: Salvador, Recife, Fortaleza, Maceió, Natal e São Luís do Maranhão, por suas belas praias e infinitas belezas naturais.

A Região Nordeste conta, além de uma extensa faixa litorânea, com lindas praias e coqueirais, extraordinárias formações geológicas que guardam testemunhos fósseis e inscrições de povos pré-históricos. Segundo os mapeamentos da Embratur, a região contém quase $50 \%$ dos pólos ecoturísticos do país. Sem dúvida, é a região brasileira com maiores contrastes de paisagem e riqueza natural, onde o Maranhão se destaca, tanto pelas belezas existentes no interior do Estado, como na sua capital.

O Maranhão é um estado com características diferentes dos demais estados do Nordeste. A sua localização fica entre as terras baixas da Amazônia, o semi-árido e o cerrado. Costuma-se dizer que o Maranhão é "Meio-Norte" ou "Outro Nordeste". Seu relevo é composto por chapadas fortemente entalhadas por rios e planícies sedimentares. $\mathrm{O}$ litoral, um dos mais belos do país, é muito recortado, fendido e extenso, com ilhas, dunas, lagoas e restingas.

Até pouco tempo, o Turismo no Maranhão era pouco difundido. Entretanto, nos últimos anos, a capital maranhense - São Luís, despontou para o Turismo, não só por ter recebido da UNESCO o título de Patrimônio da Humanidade, mas por formar um cluster ${ }^{1}$ com outras duas destinações turísticas que estão atraindo turistas do mundo inteiro - Delta do Parnaíba, conhecido como "Delta das Américas" e Lençóis Maranhenses, um lugar mágico, de uma beleza estonteante, objeto deste trabalho.

O título desta monografia “A Magia dos Lençóis Maranhenses - Uma Contribuição para o Turismo Sustentável" resulta de uma análise de depoimentos de turistas e jornalistas que expressaram os seus sentimentos através de reportagens em jornais, revistas e televisão, quando se viram envolvidos diante de uma beleza sem precedentes, - um mundo mágico, composto de rio, mar, sol, areia, morrarias (são as dunas para os nativos) e lagoas de várias tonalidades, e ao mesmo tempo, pela constatação de que um paraíso como aquele precisa ser preservado para as gerações futuras, sendo necessário um trabalho permanente, envolvendo autoridades, comunidade local e os próprios turistas, numa só 
corrente em busca de um turismo praticado de acordo com os princípios da sustentabilidade.

Este trabalho está dividido em três capítulos e considerações finais. No primeiro capítulo analisa-se o desenvolvimento do Turismo no Brasil e no Maranhão, com ênfase no Turismo Sustentável. Assim como são abordados os temas mais relevantes das atividades turísticas, tais como: o mercado turístico, os impactos econômicos, sociais e ambientais do turismo e a Imagem como produto turístico.

No segundo capítulo apresenta-se a "beleza estonteante" dos Lençóis Maranhenses, suas lagoas coloridas, dunas de todas as formas, detalhando todos os procedimentos de como chegar aos locais mais bonitos do Parque Nacional dos Lençóis Maranhenses (PNLM) - Lagoa Azul, Lagoa Bonita, Lagoa do Peixe, Vassouras, Farol de Mandacaru, Atins e Caburé, assim como os meios de transporte utilizados em Barreirinhas que levam os turistas, tanto pelas estradas de areias - uma verdadeira aventura, como pelo rio Preguiças, uma viagem inesquecível. A importância de Barreirinhas - cidade conhecida como portal dos Lençóis Maranhenses, com vocação para o Turismo de Eventos, Turismo Cultural, e Turismo Náutico. O rio Preguiças - um rio encantado, com suas belezas e lendas, considerado por todos “a riqueza do lugar”, e a Educação Ambiental.

No terceiro capítulo, apresenta-se a análise da pesquisa de campo realizada por meio de entrevistas, em duas etapas: de 02/01/03 a 10/01/03 e de 28/08/03 a 31/08/03. As entrevistas foram realizadas buscando atingir os principais atores envolvidos nas atividades turísticas nos Lençóis Maranhenses, tais como: autoridades, moradores antigos, jovens, estudantes, professores, donos de pousadas, restaurantes, agências de viagem e o ator mais importante em todo o processo turístico - o Turista.

Nas entrevistas com o turista foi elaborado um questionário contendo 12 perguntas, objetivando conhecer o seu perfil e outras questões de interesse da pesquisa.

Em considerações finais estão as contribuições deste trabalho.

\footnotetext{
${ }^{1}$ Cluster - (grupos, aglomerados) - são concentrações geográficas de empresas de determinado setor de atividade e companhias correlatas - Clusters e competitividade, Michael Porter (agosto, 1999)
} 


\title{
OBJETIVOS
}

\author{
Objetivo Geral
}

Caracterizar o turismo nos Lençóis Maranhenses alertando para a importância de se desenvolver maior conscientização e entendimento sobre a significativa contribuição que o turismo pode dar ao meio ambiente e à economia.

Objetivos específicos:

- Contribuir para a melhoria da qualidade de vida da comunidade receptora;

- Proporcionar o aumento da qualidade do meio ambiente beneficiando a população e as gerações futuras;

- Incentivar a qualificação profissional da comunidade local para suprir a demanda de empregos produzidos pelas atividades turísticas;

- Contribuir para a valorização da cultura do lugar, preservando costumes e a identidade local;

- Estimular a implantação de uma infra-estrutura pública como parte do produto turístico

\section{JUSTIFICTIVA:}

Com o asfaltamento da estrada que liga São Luís a Barreirinhas, cidade conhecida como "portas dos Lençóis Maranhenses", o percurso que antes era feito em 8 horas passou a ser feito em 3 horas, facilitando o acesso e conseqüentemente o aumento do número de turistas para os Lençóis, dando um enorme impulso às atividades turísticas e provocando um crescimento instantâneo de Barreirinhas. Outro fator que muito contribuiu para o desenvolvimento do turismo nos Lençóis foi o apoio da mídia, especialmente da televisão, que nos últimos anos vem mostrando as belezas dos Lençóis Maranhenses em diversos programas, documentários e até mesmo em telenovelas como "O Clone" da Rede Globo, 
que contribuiu significativamente para o aumento do turismo no local, da mesma forma, a Internet também vem tendo um importante papel no processo de divulgação.

Entretanto, com o acesso facilitado e a mídia divulgando as belezas de uma "destinação turística"2 emergente, em todos os seus veículos, a tendência é bastante previsível, ou seja, quanto maior o número de turistas, maior será a possibilidade de degradação ambiental. Portanto, se por um lado este trabalho tem como objetivo geral divulgar o turismo nos Lençóis Maranhenses tem também como meta contribuir para o desenvolvimento do turismo sustentável nessa importante destinação turística, mobilizando autoridades, população local e turistas para a promoção das atividades turísticas de forma duradoura e saudável, desenvolvendo uma verdadeira consciência ambiental e contribuindo também para uma melhor qualidade de vida.

\section{METODOLOGIA}

Neste trabalho foram utilizados dois tipos de pesquisa: Pesquisa Bibliográfica levantamento de todas as obras que serviram como base na sua fundamentação teórica: revistas, jornais, livros, vídeos e Internet.

Pesquisa de campo - levantamento de dados nos Lençóis Maranhenses, especificamente em Barreirinhas, cidade que dar suporte a todas as atividades turísticas do lugar. Além de filmar e fotografar os principais pontos turísticos do lugar, foram realizadas diversas entrevistas objetivando colher informações sobre o desenvolvimento do turismo no local. Para tanto se selecionou pessoas com os conhecimentos necessários para o total alcance dos objetivos da pesquisa, tais como: Secretário de Turismo Cultura e Meio Ambiente, Gerente de Educação Ambiental, Promotor de Eventos, um Sociólogo e Assessor da Secretaria de Turismo, Gerente do Parque dos Lençóis, um Instrutor do Senac - Unidade Móvel em Barreirinhas, que ministra cursos de Atendente Turístico, uma funcionária do SEBRAE - responsável pela orientação dos trabalhadores que produzem o artesanato da cidade, uma das principais fontes de renda da região, gerentes de pousadas, guias turísticos, professores, moradores pioneiros e o principal ator do processo turístico o turista. 
Para tanto, foi montado um planejamento, onde além da escolha dos entrevistados, foram elaboradas, com antecedência, as perguntas a serem feitas aos entrevistados. Para as autoridades locais verificou-se quais as políticas do município de Barreirinhas para o desenvolvimento do turismo nos Lençóis Maranhenses, como a cidade estava se preparando em termos de infra-estrutura para receber um número cada vez maior de turistas, considerando a grande divulgação do lugar pela mídia; Para os gerentes de pousadas, a questão era descobrir o perfil do turista que visita os Lençóis, quanto tempo ele fica, em média, no local e quanto gasta; Para os professores: o que as escolas e demais entidades educativas estavam passando para os alunos e a população em geral, em termo de Educação Ambiental, para os turistas - qual a imagem que eles levam dos Lençóis Maranhenses, incluindo o tratamento recebido nas pousadas, nas empresas de turismo responsáveis pelos passeios e o relacionamento com a comunidade local.

\footnotetext{
${ }^{2}$ Destinação Turística - "um local ou espaço geográfico apropriado para visitas e/ou hospedar pessoas que buscam lazer e demais serviços relacionados com as atividades turísticas"
} 


\section{CAPÍTULO - 1}

\subsection{Análise do desenvolvimento do turismo no Brasil, no período de 1995 a 2002.}

O turismo é uma das mais notáveis histórias de sucesso dos tempos modernos. Embora seja um fenômeno praticado desde as antigas civilizações, a atividade turística, segundo Frangialli - Secretário-Geral da Organização Mundial de Turismo, teve o seu crescimento acelerado a partir da década de 1960, tendo uma evolução rápida e constante nos últimos 30 anos.

Nas últimas décadas o turismo se constituiu em um dos maiores setores da economia mundial e de modo visível no Brasil, de acordo com Luiz Trigo em Turismo Global (2002 p. 11), a partir de meados de 1990, período em que o país presencia a segunda fase de desenvolvimento do turismo, sendo que a primeira correu no inicio da década de 1970, em pleno governo militar, "não bem sucedida".

De 1990 até os dias atuais a indústria do turismo evoluiu de tal forma que até o seu conceito, de acordo com a Organização Mundial de Turismo (OMT) "a soma de relações e de serviços resultantes de mudança de residência temporária e voluntária motivada por razões alheias a negócios ou profissões", ficou descaracterizado, levando-se em conta que nesses últimos tempos surgiram diversas modalidades de turismo, a partir da "segmentação de mercado", com a identificação de clientes com comportamentos homogêneos quanto a gostos e preferências. "A segmentação possibilita o conhecimento dos principais destinos geográficos, dos tipos de transporte, da composição demográfica dos turistas e da sua situação social e estilo de vida, entre outros elementos" conforme deixa explícito Luiz Gonzaga Trigo ${ }^{1}$ em seu livro Como Aprender Turismo Como Ensinar. (2001 p. 27).

\footnotetext{
${ }^{1}$ Luiz Gonzaga Godoi Trigo é Diretor da Faculdade Senac de turismo e Hotelaria, S. Paulo.
} 
A segmentação de mercado vem sendo abordada de várias maneiras por diversos estudiosos do turismo. Para $\mathrm{Vaz}^{2}$, a segmentação de mercado tem as seguintes características:

a) Segmentação demográfica pessoal

. Turismo infantil;

. Turismo juvenil;

. Turismo da terceira idade;

. Turismo romântico;

. Turismo familiar;

. Turismo (GLS);

. Turismo de saúde;

. Turismo para deficientes (portadores de necessidades especiais).

b) Segmentação demográfica sócio-cultural

. Turismo de estudo;

. Turismo cultural;

. Turismo de raízes;

. Turismo religioso.

c) Segmentação demográfica socioeconômica

. Turismo de eventos;

. Turismo de negócios;

. Turismo comercial;

. Turismo de incentivo;

. Turismo Social

${ }^{2}$ Gil Nuno Vaz, Marketing Turístico São Paulo, Pioneira, 1999) 
d) Segmentação psicográfica

. Turismo surpresa;

. Turismo - aventura;

. Turismo esportivo;

. Turismo gastronômico;

. Turismo hidroviário;

. Turismo ecológico/rural;

e) Segmentação comportamental

. Turismo de época.

Entretanto, ao elencar essa classificação, Vaz deixa claro que com isso não teve a intenção de esgotar o assunto, pois o mercado turístico é dinâmico, podendo surgir outros seguimentos que poderão ser analisados e incorporados aos já citados.

Com a segmentação do mercado turístico, verifica-se uma explosão do turismo em todos os cantos do país, com o surgimento de pólos turísticos até então não identificados, apesar de já existirem há décadas, tendo como conseqüência, o surgimento de um grande número de escolas e cursos de todas as modalidades: qualificação profissional, cursos técnicos, de graduação e pós-graduação, em várias cidades brasileiras, reduzindo consideravelmente um dos grandes problemas do setor, - a falta de profissionais qualificados para ocupar os empregos gerados pelas atividades turísticas, apesar de ainda existir uma grande carência nesse sentido e um batalhão de trabalhadores do setor turístico sem nenhuma qualificação profissional, com prestação de serviços de baixa qualidade.

Como o turismo é uma atividade complexa, envolvendo diversos setores da economia, o seu crescimento fica um tanto difícil de medir, pois engloba inúmeras variáveis. Entretanto, o Ministério do Esporte e Turismo a través da Embratur, no cumprimento do seu dever de prestar contas à sociedade dos seus trabalhos realizados, publicou um importante trabalho denominado "O Turismo no Brasil - Principais Evoluções: 1995/2002”.

Os dados estatísticos da Embratur - Instituto Brasileiro de Turismo, traduzem um período que foi chamado por Caio Luiz de Carvalho de "A Nossa Revolução Silenciosa", onde o turismo no Brasil passa a ser notado por brasileiros e extrapolam as nossas 
fronteiras, sendo visto também por estrangeiros que não resistem e se entregam ao fascínio das belezas naturais que possuímos, apesar das imagens negativas que são divulgadas no exterior, tendo a violência como o nosso principal marketing negativo, nos impedindo de atrair um número muito maior de turistas estrangeiros. Mesmo assim, os resultados do período analisado pela Embratur são notáveis.

Houve um crescimento considerável do fluxo de turistas estrangeiros no Brasil, saltando de 1,85 milhões em 1994, para mais de 5 milhões, em 2000. No mesmo período, o turismo interno cresceu de 13,85 milhões para 38,20 milhões de brasileiros, viajando pelos quatro cantos do país. A receita cambial gerada pelo turismo chegou a US\$ 4,2 bilhões, em 2000. Se na América do Sul e no mundo o turismo teve um crescimento de 35,5\% nos últimos oito anos, conforme dados da OMT (Organização Mundial do Turismo), no Brasil, no mesmo período, o incremento da receita gerada pelo turismo foi de $95 \%$.

Segundo dados da Embratur, de 1995 a 2002, o turismo dobrou a receita gerada pelas suas atividades e gerou 6 milhões de empregos. Hoje, representa cerca de $4 \%$ do PIB Nacional - US\$25,8 bilhões. Graças aos esforços do governo federal, "que dispensou especial atenção aos investimentos em infra-estrutura turística, qualidade de serviços, preservação, construção e consolidação de novos produtos e roteiros", se em 1995 o país contava com 50 destinos turísticos consolidados, em 2002 esse número saltou para 300 destinações turísticas oferecendo qualidade de serviços, facilidade de transportes, boa infra-estrutura hoteleira e diferenciais criativos.

De acordo com a opinião de especialistas no assunto, outro fator que contribuiu de forma decisiva para o desenvolvimento do turismo no Brasil, foi a transferência da Embratur do Rio de Janeiro para Brasília e a profissionalização do seu quadro de pessoal, isto deu um novo impulso ao setor. O turismo recebeu um tratamento especial, sendo criado o Ministério da Indústria, Comércio e Turismo, recebendo a partir de 1999, o nome de Ministério do Esporte e Turismo, ficando por conta da Embratur a elaboração e a execução da Política Nacional do Turismo (PNT), que serviu como " plano de vôo" para as mudanças que ocorreram no cenário do turismo nacional tendo como princípios:

. Promover o desenvolvimento local sustentável nos municípios turísticos; 
- Criar ambiente para a geração de empregos, redução das desigualdades regionais;

- Inserção competitiva do Brasil no mercado internacional visando aumentar as exportações e gerar receitas cambiais;

- Garantir direitos e qualidade na prestação de serviços turísticos ao consumidor.

Entretanto, era preciso mudar a imagem do país no exterior. A Embratur promoveu uma intensa campanha de marketing visando transformar a imagem do Brasil, até então negativa, em imagem positiva, conseguindo com isso "ampliar o sentimento de brasilidade e despertar o interesse internacional pelo produto Brasil". Conforme a Embratur, os brasileiros passaram a conhecer mais e melhor o país e a deixar receitas dentro de nossas fronteiras". No exterior, as ações de marketing resultaram em aumento significativo do fluxo turístico, da taxa de permanência e do gasto médio dos visitantes estrangeiros no País.

É importante destacar os programas e campanhas educativas desenvolvidas pela Embratur em busca da excelência do turismo brasileiro, tais como:

. O PNMT - Programa Nacional de Municipalização do Turismo, que desenvolve o turismo nas comunidades brasileiras de forma sustentável, tornou-se modelo mundial de desenvolvimento social;

. A Campanha de combate à Exploração do Turismo Sexual Infanto-Juvenil, lançado em parceria com o Ministério da Justiça e diversas instituições identifica operadoras ou agências que vendam pacotes de turismo sexual com destino ao Brasil, teve grande repercussão junto à OMT, que adotou a logomarca criada para a campanha brasileira como símbolo oficial da sua própria campanha;

- O Programa Embarque Nessa, com a parceria dos Ministérios do Esporte e Turismo, Educação e Cultura, distribuiu mais de um milhão de cartilhas em todo o território nacional, enfatizando a valorização e proteção do patrimônio natural e cultural do Brasil, além de ressaltar a importância do turismo para o desenvolvimento social e econômico das localidades; 
. O Guia Brasileiro de Sinalização Turística, que normatizou símbolos educativos para motoristas, pedestres e ícones históricos, pioneiro no mundo, tornou-se referência internacional.

Diante de todas essas ações de governo, sem as quais não há desenvolvimento turístico, o turismo no Brasil se transformou numa indústria gigante, surgindo como conseqüência um problema muito sério, - a falta de pessoal qualificado para ocupar os empregos gerados pelo setor. Mesmo com o surgimento de várias faculdades, de cursos de qualificação profissional e cursos técnicos ministrados por instituições como SENAC e SENAI, ainda existe um batalhão de pessoas trabalhando nas atividades turísticas, sem nenhuma qualificação profissional e prestando um serviço de baixa qualidade. Sabe-se que o turismo é uma atividade complexa, que funciona como um sistema, onde é preciso conhecer os seus diversos setores que se inter-relacionam, se complementam e que precisam ser entendidos e considerados conjuntamente.

Para a OMT, no conceito da atividade turística se distinguem quatro elementos básicos:

. A Demanda - formada pelo conjunto de consumidores ou possíveis consumidores de bens e serviços turísticos;

. A Oferta - composta pelo conjunto de produtos, serviços e organizações envolvidas ativamente na experiência turística;

. O Espaço Geográfico - base física onde tem lugar a uma conjunção ou encontro entre a oferta e a demanda e onde se situa a população residente - pode ser ao mesmo tempo um destino turístico;

. Os Operadores do Mercado - são empresas e organismos, cuja função principal é facilitar a inter-relação entre a oferta e a demanda. Entram nessa consideração as agências de transporte e organismos públicos e privados que mediante seu trabalho profissional são artífices da ordenação e promoção do Turismo.

Outro fator importante para se entender melhor a evolução do turismo, além de conhecer os seus elementos básicos, é acompanhar as suas tendências.

$\mathrm{O}$ estudo do turismo na atualidade deve ser direcionado para o "desenvolvimento sustentável"3. É preciso considerar que o êxito do desenvolvimento turístico está diretamente ligado à proteção do meio ambiente. 
"Depende de nós,

Se esse mundo ainda tem jeito,

Apesar do que o homem tem feito,

Se a vida sobreviverá"

( Depende de nós, Ivan Lins e Vitor Martins)

Ao longo dos tempos, o nosso planeta vem sofrendo constantes transformações, causadas tanto por agentes naturais como pelo homem. Hoje, debita-se ao turismo, muitas vezes de forma injusta, grande parte dos problemas causados ao meio ambiente. Entretanto, em toda a história da humanidade o planeta terra sofreu agressões por parte do homem muito antes de se falar em atividades turísticas.

Historicamente, o homem sempre utilizou recursos naturais em seu benefício, como a água, a madeira e todos os alimentos extraídos da terra, dos rios, agredindo a natureza, embora de forma inconsciente, - caso dos homens primitivos, o que os não diferenciam dos homens atuais. Só que estes agridem o meio ambiente conscientemente.

A forma cruel como o planeta terra foi tratado durante toda a sua existência pode ser retratada no fato de que somente na década de 60, após alerta de estudiosos, que a humanidade começou a tomar consciência das agressões cometidas contra a natureza e se perguntou: "Caso o homem não aprenda a viver em harmonia com os elementos naturais, quais são as perspectivas de vida?”.

Somente 12 anos depois, em 1972, depois de tomar consciência da degradação do meio ambiente, causada por todos os tipos de agressões como: explosões nucleares, poluição do ar e das águas, destruição de florestas e animais, - várias espécies extintas ou em processo de extinção, foi que a Organização das Nações Unidas (ONU) realizou a primeira reunião sobre o meio ambiente, que recebeu o nome de ECO-72. A partir desse encontro o mundo começou a falar em ecologia e o turismo seguiu o caminho, criando o seu mais nobre produto - o ecoturismo - turismo sustentável.

\footnotetext{
${ }^{3}$ Ler: Faria e Carneiro, Sustentabilidade Ecológica no Turismo, (Editora UNB, 2001)
} 


\section{2 - Turismo Sustentável}

Vários estudos têm demonstrado que o aspecto mais crítico para o desenvolvimento do turismo é a estabilidade das atividades turísticas em altos padrões de desempenho. Para Faria e Carneiro, se após o incremento das atividades turísticas em uma localidade houver um declínio, resultante ou não de um modismo imediatista e/ou de uma depauperação das conduções locais, pode ser minimizado o problema se o processo tiver sido planejado de acordo com os princípios da sustentabilidade, de modo a gerar melhores condições mais estáveis e duradouras.

Ao longo da história de desenvolvimento do turismo como atividade econômica, observa-se que a sua relação com o meio ambiente ocorre, especialmente, por meio da paisagem, sendo que a mesma vem sendo utilizada de maneira indiscriminada como divulgação da oferta.

São bastante conhecidos os dois lados das atividades turísticas. Se por um lado o turismo é visto como importante fator da valorização do meio ambiente, por outro lado é acusado como responsável pela degradação ambiental.

De acordo com Ruschmann ${ }^{1}$, o turismo e o meio ambiente não têm se caracterizado por um relacionamento harmonioso, porém atualmente, surgem indícios que sua interação seja crescente e profícua para ambos.

Diante da importância que a atividade turística representa para a economia, especialmente pelo seu crescimento contínuo, considerando que quanto maior o fluxo de pessoas numa destinação turística, maior a possibilidade de degradação ambiental, faz-se presente em todas as reuniões técnicas e científicas do setor a discussão sobre novas formas de turismo.

\footnotetext{
${ }^{1}$ Ruschmann, D. Van de M. 1997, Turismo e Planejamento Sustentável, Papiros, Ed São Paulo.
} 
Em todas as destinações turísticas encontra-se um certo desconforto e opiniões negativas a respeito do turismo de massa - que tem como característica "O deslocamento de grande número de pessoas para os mesmos lugares, nas mesmas épocas do ano". Essa forma de turismo não configura a rentabilidade esperada, pelo pouco tempo que essas pessoas passam no lugar, pelas agressões socioculturais às comunidades receptoras e pelos danos causados ao meio ambiente, às vezes irreversíveis, sendo esse tipo de turismo o maior responsável pelos impactos negativos da atividade.

\subsection{Impactos do Turismo sobre o Meio Ambiente:}

Os impactos do turismo sobre o meio ambiente representam um fenômeno presente em todos os estudos realizados sobre o setor. Há impactos de toda natureza, porém, neste trabalho, enfoca-se apenas os impactos econômicos, ambientais e sociais.

Inúmeros pesquisadores já estudaram os efeitos econômicos do turismo nas localidades receptoras, tanto em nível local, regional, como nacional e, geralmente, em detrimento daqueles relacionados com o meio ambiente físico e sociocultural, por ser mais fácil de medir. "Os demais impactos possuem certos componentes intangíveis e difíceis de mensurar e sua avaliação é altamente subjetiva". Quando se trata de estudos sobre impactos provocados pelas atividades turísticas, são levados em consideração tanto os impactos positivos quanto os negativos.

\section{Impactos Econômicos:}

Para que o turismo proporcione efeitos econômicos positivos nas destinações, Mathieson e Wall (1988, p.52) relacionam os seguintes fatores que derivam diretamente da amplitude da atividade.

. A natureza dos componentes e dos recursos e sua atratividade para os turistas;

. O volume e a intensidade dos gastos do turista nas destinações;

. A base econômica da destinação;

. O grau de distribuição e de circulação das despesas realizadas;

. O Grau de adaptação do local a sazonalidade da demanda turística. 
Esses fatores também determinarão se os impactos econômicos serão favoráveis ou não.

Para Serrano, em (Olhares Contemporâneos sobre o Turismo, Papirus 2000) os impactos positivos do turismo são os seguintes:

. Geração de emprego, renda e estímulo do desenvolvimento econômico em vários níveis (local, regional, estadual, nacional);

. Estímulo à comercialização de produtos locais de qualidade;

. Fixação das populações locais graças à geração de emprego e renda;

. Possibilidade de melhoria dos equipamentos Urbanos e de infra-estrutura (viária, sanitária, médica, de abastecimento e de comunicação);

. Ampliação dos investimentos voltados à proteção de áreas naturais e bens culturais.

. Sensibilização de turistas e populações locais para a proteção do ambiente, do patrimônio histórico e de valores culturais; e,

. intercâmbio de idéias, costumes e estilo de vidas.

\section{Impactos negativos do turismo:}

- Aumento do custo de vida, supervalorização dos bens imobiliários e consequentemente perda da propriedade de terras, habitações e meios de produção por parte das populações locais;

. Substituição de ocupações tradicionais por subempregos;

- Esgotamento do solo e transformação negativa de paisagem pela implantação de construções e infra-estrutura;

. Geração de fluxos migratórios para áreas de concentração turística:

. Adensamentos urbanos não planejados e favelização;

. Incremento do consumo dos recursos naturais podendo levar ao seu esgotamento;

. Poluição do ar, visual e dos recursos hídricos;

. Aumento da produção de lixo e detrito nas localidades receptoras;

- Alteração de ecossistemas naturais devido à introdução de espécies exóticas de animais e plantas;

. Estímulo ao consumo de suvenires produzidos a partir de elementos naturais, raros; e,

. Perda de valores tradicionais em conseqüência da homogeneização das culturas. 
Nas Unidades de Conservação (UC), para Serrano existem impactos positivos e negativos do Turismo.

\section{Impactos Positivos:}

. Sustentação econômica da UC;

. Integração da UC com as populações locais.

.Circulação de informações sobre meio ambiente;

. Aumento da oferta de atividades de lazer e recreação;

. Ampliação da capacidade de fiscalização;

. Controle sobre grupos; e,

. Divulgação da UC.

\section{Os impactos negativos:}

. Pisoteamento, compactação, erosão e abertura de atalhos em trilhas;

. Depredação da infra-estrutura e de atrativos e elementos naturais;

. Estresse e desaparecimento da fauna em razão da presença humana (provocados por barulho, cheiro e cores estranhos ao ambiente);

. Aumento e/ou deposição inadequada do lixo;

. Necessidade de "sacrifício" de áreas para instalação de infra-estrutura; e, . Aumento de risco de incêndios.

\section{Impactos Sociais do Turismo:}

Foram identificados cinco estágios de crescente desilusão com a atividade turística conforme Doxey, em Mathieson e Wall (1998, p. 38), que os caracterizados da seguinte forma:

. O estágio inicial é o da euforia, no qual as pessoas estão entusiasmadas e vibram com o desenvolvimento do turismo. Recebem os turistas e registram-se entendimentos de satisfação mútua. As oportunidades de emprego, negócios e lucros são abundantes e aumentam com o crescimento do número de turistas; 
. A segunda fase é a da apatia, na medida em que a atividade cresce e se consolida a população receptora considera a rentabilidade do setor como garantia e o turista passa a ser considerado um "meio" para a obtenção de lucro fácil, o que torna os contatos humanos mais formais do que no estágio anterior;

- A irritação caracteriza a terceira fase, que se manifesta conforme a atividade turística começa a atingir níveis de saturação ou quando já não consegue atender as exigências da demanda que quantitativamente excessiva, torna os equipamentos existentes incapazes de atendê-las;

. O quarto nível caracteriza-se pelo antagonismo. Os moradores já não disfarçam sua irritação e responsabilizam os turistas por todos os seus males e pelos problemas da comunidade, tais como aumento de impostos, de criminalidade, de desajuste da juventude, dentre outros. A polidez e o respeito mútuo desaparecem, dão lugar ao antagonismo e o turista passa a ser hostilizado pela população da localidade receptora;

. O quinto e último estágio ocorrem quando a população se conscientiza de que, na ânsia de obter todas as vantagens da atividade turística, ela não considerou as mudanças que estavam ocorrendo e nem pensou em impedi-las. Agora terá de conviver com o fato de que o seu ecossistema jamais voltará a ser o que era antes do advento do turismo. Ela poderá tentar atrair outro tipo de turista diferente do que recebeu com euforia no passado, ou então, se a destinação for suficientemente grande para absorvê-lo, o turismo de massa continuará a crescer - com ou sem a aprovação da população local.

É importante dizer que o estudo de Doxey foi realizado em Barbados, mas as cinco fases detectadas ocorrem em outros lugares, inclusive no Brasil, como já ocorreu em Camboriú - Santa Catarina.

O movimento do turismo em Camboriú apontou historicamene tendências de crescimento, com variações positivas até a estação de verão dos anos 2000/2001, considerado um marco turístico nacional e internacional. A partir de 2001, após os atentados terroristas de 11 de setembro nos Estados Unidos, o turismo sofreu uma retração com reflexo mundial, modificando as previsões até então traçadas. Ficou claro para o Brasil e principalmente para o município de Balneário Camboriú, que o planejamento deveria ser revisto, em 
função do novo quadro turístico que se apresentava, exigindo um redirecionamento dos negócios. (Planejamento Turístico Balneário Camboriú, Univali 2002).

Diante disso, as atividades turísticas estão sujeitas, independentemente do tipo de destinação ou tipo de turismo, de sofrer impactos provenientes de mudança de cenários, quer sejam políticos, econômicos e por fenômenos naturais, por serem consideradas "complexas", carecem de um planejamento sistêmico.

Segundo Beni (2001, p. 45-46) 'o planejamento em turismo requer uma análise das inter-relações de que trata o Sistema de Turismo - SISTUR*, principalmente das questões relacionadas com a infra-estrutura, com a superestrutura, com a demanda, a oferta e os sub-sistemas ecológico, econômico, social e cultural”.

No caso dos Lençóis Maranhenses, os impactos ambientais tanto na região dos Pequenos Lençóis que se estende a partir da margem direita da foz do rio Preguiças (Brasília, Caburé, Moitas, Morro do Boi, Espadarte, Vassouras e Alazão até o Delta do Parnaíba, considerada Área de Preservação Ambiental (APA), como também na área dos Grandes Lençóis (PNLM), são previsíveis à medida que as atividades turísticas vão se desenvolvendo, atraindo cada vez mais um número maior de turistas.

Com o Turismo assumindo um lugar de destaque na economia local, a pressão imobiliária aparece em primeiro plano como elemento ameaçador no que se refere à degradação ambiental, - é o grande fator causador de impactos negativos nas destinações turísticas tipo Lençóis Maranhenses, onde a natureza é o principal recurso turístico.

O rio Preguiças poderá ser a grande vítima nos próximos cinco anos, caso as autoridades de Barreirinhas, responsáveis pelo desenvolvimento do turismo local e pela preservação dos seus recursos naturais, não tomem as devidas providências tais como: proibir o desmatamento nas margens do rio e inibir o processo de construção de complexos turísticos ao longo desse rio que é juntamente com as dunas e lagoas o que compõe "A Magia dos Lençóis Maranhenses"

-Mário Carlos Beni, Análise Estrutural do Turismo, São Paulo, Editora Senac São Paulo, 2003. 


\section{4 - Turismo e Imagem}

O produto turístico é repassado para o mundo pela publicidade, por meio de suas imagens estonteantes. Não há como contemplar uma bela imagem sem o desejo de conhecê-la. Assegura Baudrillard (1993:188) "Vivemos nossos desejos por referência coletiva, a publicidade se empenha, todavia, em transformar tal circunstância na dimensão sistemática do desejo".

No turismo, usa-se, com certa freqüência, a imagem mental, aquela que envolve a criação de uma fantasia ou de um sonho. Passamos a imaginar o lugar como se estivéssemos lá.Uma representação mental é elaborada de maneira quase alucinatória, uma transposição do real ao imaginário. Nesse aspecto, muitas vezes o turista faz uma viagem na mente antes de se deslocar de fato. A mídia exerce um papel fundamental nesse processo por meio da folhetaria ricamente ilustrada, das propagandas televisionadas e dos anúncios impressos. Cria-se um mundo metafórico, as imagens nem sempre representam o que são, elas se servem das coisas para falar de outra coisa. (Joly, 1999:14).

Mas afinal, o que significa imagem? A palavra imagem pode ter vários significados. "Pode ser associada a um conjunto de percepções a respeito de algo, a uma projeção futura, a uma lembrança ou recordação passada".

No turismo, para o marketing de lugares e serviços, pode-se dizer que não importa tanto qual imagem irá representar um produto, mas o que importa é que ela seja atrativa e principalmente que ela não se distancie inadequadamente da realidade.

Uma imagem pode ser construída de forma positiva ou negativa. A mídia tem o poder de transformar esses significados conforme o seu interesse, quer seja econômico ou político, o certo é que as imagens turísticas podem ser definidas pela literatura, a televisão, o cinema, dentre as principais fontes de informações. "Vários lugares após terem sido vistos ou conhecidos por meios de comunicação, tiveram aumento significativo do número de turistas". O exemplo mais recente pode ser citado - a TV Globo mostrou em sua novela "O Clone" toda a beleza dos Lençóis Maranhenses e turistas do Brasil inteiro, assim como de outros países, não param de verificar de perto "a magia do deserto brasileiro". 


\section{5 - Turismo no Maranhão:}

Tudo começa em São Luís, a bela capital do estado. As praias são muitas e para todos os gostos. Dunas de areias brancas e fontes de água doce estão por todo lugar. Ponta de Areia e São Marcos são as mais movimentadas. Outra praia que é considerada o orgulho da cidade é Araçagi, com vasta extensão de areia e muitas dunas, uma delas com um pequeno castelo encravado em suas areias. Os surfistas preferem a praia da Marcela, que é uma verdadeira festa. Vale a pena conhecer também a Raposa, antiga vila de pescadores, onde várias famílias cearenses transformaram o lugar num grande mercado de artesanato, especialmente bordados. Saindo da Raposa é importante conhecer São José de Ribamar, uma cidadezinha aconchegante que tem o nome do padroeiro do Maranhão e de milhares de maranhenses.

\footnotetext{
Ponta de areia, olho d'água e Araçagi.

Mesmo estando na Raposa, eu sempre vou ouvir,

A natureza me falando,

Que o amor nasceu aqui.

( Ilha Magnética - César Nascimento)
}

São Luís é chamada - carinhosamente, de "Ilha do Amor" dentre muitos outros títulos da cidade. Gonçalves Dias, o maior poeta romântico do Brasil, é maranhense e uma das praças mais freqüentadas de São Luís tem o seu nome, - é ponto de encontro dos namorados ao entardecer. Além de Gonçalves Dias, o Maranhão é berço de ilustres escritores, conhecidos internacionalmente, como Coelho Neto, Humberto de Campos e Graça Aranha, dentre outros.

Cidade de muito agito cultural, São Luís tem ainda a Fundação da Memória Republicana (Memorial José Sarney), localizado no antigo convento das Mercês, cujo acervo compreende cerca de 40 mil livros, 500 mil documentos, sendo 80 mil manuscritos, além de quadros, esculturas e artesanatos de diversos países e museu sacro com 2500 peças; a Casa de Cultura José Montello, cuja biblioteca abriga mais de 20 mil volumes e preciosidades publicadas no século 19; e o teatro Artur Azevedo (1817), restaurado em 
1993, que vem se revelando um relevante pólo de experiências teatrais, líricas, musicais e de dança no país.

A cultura maranhense é muito forte e até certo ponto misteriosa, como o seu povo. Mesmo tendo a sua cidade fundada pelos franceses, dominada por algum tempo pelos holandeses e depois reconquistada pelos portugueses, o traço marcante do ludovicense (nascidos em São Luís) vem mesmo é da África. Povo alegre, brincalhão, que adotou o reggae como o seu ritmo preferido, além do forró que está no sangue do maranhense, tem o bumba-meu-boi como a sua festa maior. Durante o mês de junho, tanto nos bairros de São Luís como nas cidades do interior do estado, as agremiações reúnem-se para dançar e cantar seus enredos, ao som de zabumbas, matracas e pandeiros.

Além do bumba-meu-boi, outras danças compõem o folclore maranhense - a dança do coco e tambor de crioula, evidenciam as raízes africanas e apesar da alma lusitana dizem que o maranhense "tem os dois pés na Jamaica". O carnaval, que geralmente começa em janeiro, é outra grande razão para tornar o maranhense o povo mais festeiro do Brasil. Não há quem não fique enfeitiçado nessa terra de muitas palmeiras "onde canta o sabiá".

Bem pertinho de São Luís, só uma hora de barco e uma boa dose de coragem para atravessar a perigosa Baía de São Marcos, está a misteriosa e encantadora Alcântara, uma das mais ricas e importantes cidades do Estado durante os séculos XVIII e XIX. "A visão que se tem da cidade quando o barco se aproxima do Porto do Jacaré é inesquecível”. Para Cristina Ramalho (revista viagem, fevereiro de 2000), "a beleza de Alcântara é como a daquelas mulheres que ganharam certas marcas do tempo e acabaram mais sugerindo do que exibindo". Cidade histórica, Patrimônio Nacional, cheia de lendas, combina passado e futuro, já foi presídio, hoje, a poucos quilômetros dos casarões e ruínas, abriga a mais moderna base de lançamento de foguetes da América do Sul.

O conjunto arquitetônico que restou impressiona com suas séries de janelões de batentes de pedra, sacadas de ferro, paredes de pedra e cal, com mirantes e azulejos portugueses. Ao final, a grande praça gramada e arborizada de onde se avista o mar, circundada por casarões dos séculos 17 e 18. Um deles abriga o Museu Histórico de Alcântara, com peças de arte sacra que pertenciam as igrejas da cidade, mobiliário do Império, objetos e fotos que contam histórias antigas do lugar. Bem no centro ficam as ruínas da igreja matriz de São Matias (1648) e o Pelourinho (1648), que foi restaurado 
em 1948, depois de ficar 50 anos soterrado. Saindo da praça fica a Rua da Amargura, onde estão as ruínas do prédio em que funcionava o mercado de escravos negros e de vários palacetes de antigos barões. Seguindo pelas ruas Direita e Grande, mais igrejas, como a de Nossa Senhora do Rosário dos Pretos (1777), e ruínas, como as duas casas do Imperador, que começaram a ser construídas pela aristocracia de Alcântara para receber D. Pedro II que, no entanto, nunca visitou a cidade. (Embratur, pontos turísticos do Brasil, 2000.)

Apesar da controvérsia que gira em torno da base de lançamento de foguete de Alcântara, pelas negociações do Brasil com os Estados Unidos, onde um forte sentimento de nacionalismo faz com que brasileiros de todos os cantos do país que visitam a cidade se sintam "estrangeiros na sua própria terra", a cidade continua atraindo um grande número de turistas.

Além de São Luís e Alcântara, dois pontos turísticos de grande relevância para o Maranhão vêm contribuindo para o desenvolvimento do turismo no Estado. Trata-se de Carolina, uma cidadezinha que fica na divisa com o Tocantins, de uma beleza extraordinária, onde os principais atores são "a pedra e a água”. As belezas ficam por conta das cachoeiras, numa região que foi batizada como "Chapada das Mesas".

As pedras, que parecem ruínas muito antigas, formam esculturas em formato de mesas, de vários tamanhos e de diferentes formas. A água, transparente, reflete as cores do sol nas rochas. Dentre as várias cachoeiras, a mais bonita é a do Santuário da Pedra Caída. "Ao vê-la, depois de caminhar por trilha de pedras e descer 110 degraus por um cânion de 300 metros, confirma-se que, de tanto bater, a água lapidou a rocha”.

O Delta do Parnaíba, embora muita gente relacione esse importante ponto turístico com o estado do Piauí, pois para conhecer esse riquíssimo ecossistema composto de mangue, lagoas, praias desertas e dunas, o passeio começa na cidade piauiense de Parnaíba, a parte principal do delta (nome que se dá à foz do rio que se bifurca num formato triangular) fica no Maranhão. Na verdade, o Delta do Parnaíba é um prolongamento das belezas dos Lençóis Maranhenses.

Portanto, o Maranhão é uma viagem que começa “com o fado nas fachadas e o reggae nas ruas de São Luís, segue pelas ruínas de Alcântara, cachoeiras de Carolina, Delta do Parnaíba e culmina nas dunas mágicas dos Lençóis Maranhenses”. 


\section{Capítulo - 2}

\section{1 - Lençóis Maranhenses}

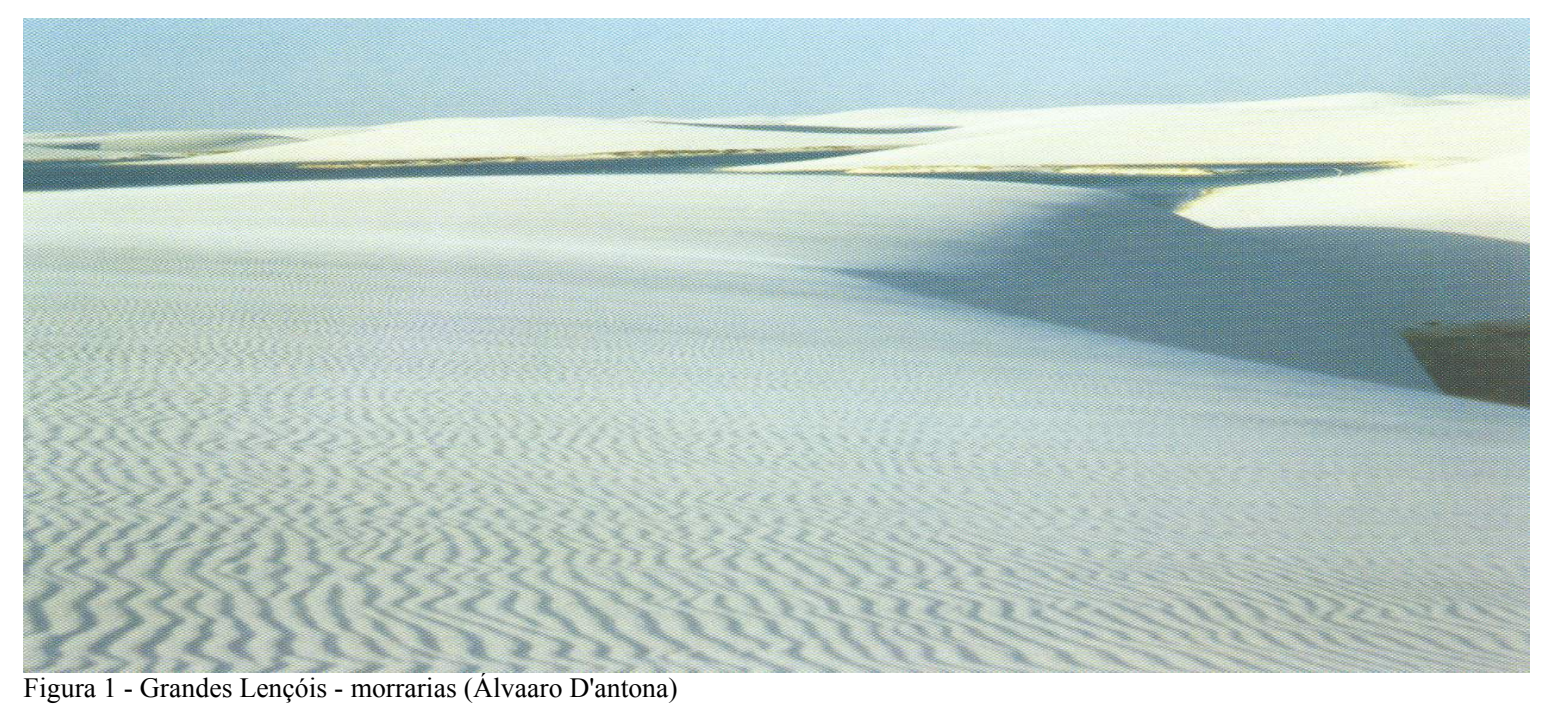

Dizem que o Brasil é um país “abençoado por Deus e bonito por natureza". No entanto, olhando os Lençóis Maranhenses conclui-se que aqui a natureza resolveu se exibir. O lugar recebeu esse nome, porque vendo esse mundo de areia branca cheia de dobras feitas pelos fortes ventos que sopram o tempo todo, tem-se a impressão de se está diante de uma cama coberta com lençóis brancos, desarrumados.

Costumam chamar os Lençóis Maranhenses de Saara Brasileiro, como batizaram Recife de Veneza Brasileira, entretanto isso faz lembrar as artimanhas do turismo que tem o hábito de criar verdadeiros simulacros - os não-lugares ${ }^{1}$. Esse pecado não deve ser cometido com um lugar único, mágico, que não deve ser comparado com nenhum outro lugar do mundo, como é o Parque Nacional dos Lençóis Maranhenses, daqui em diante chamado de PNLM. Mas, como surgiu esse magnífico cenário?

"No litoral irregular do Maranhão, as correntes marítimas favorecem o acúmulo da areia ali despejada pelos rios Preguiças e Parnaíba. Com o recuo da maré, larga faixa de praia fica exposta ao sol, que seca a finíssima areia de quartzo e facilita o seu transporte por ventos de até 70 quilômetros por hora que sopram do oceano. Assim se teriam formado as dunas, em 10 milhões de anos, ao longo de um trecho de 70 quilômetros de costa. Elas avançam 50 quilômetros sobre o continente e atingem mais de 20 metros de altura. Conforme os ventos, chegam a se deslocar até 20 metros em um ano. Como nesse deserto brasileiro chove 1600 milímetros anuais, (mais de 300 
vezes do que no Saara), de dezembro a julho, há uma proporção de uma lagoa para cada duna. Muitas delas secam, mas não totalmente. $\mathrm{O}$ fundo poroso e barrento permanece úmido, acolhendo e conservando os ovos de peixe ali depositados. Assim o ciclo reprodutivo não é interrompido. Os peixes alimentam árvores migratórias como a marreca, o trinta-réis-boreal e o maçarico-rasteirinho, procedente do ártico. Tartarugas de diferentes espécies são vistas junto ao mar, na época da desova. Pacas e veados-mateiros destacam-se entre os mamíferos. Inúmeros peixes, crustáceos e moluscos habitam a região de manguezais na ponta noroeste do PNLM, criado em 1981, ainda hoje um dos mais agrestes do país. (Revista Terra, setembro, 2002)".

As imagens que são passadas pela mídia por meio de revistas, jornais ou pela televisão, transformam o PNLM num sonho de consumo, tanto do ponto de vista dos turistas, que seguindo uma tendência do mercado turístico, onde o turismo ecológico ganha cada vez mais adeptos, como também dos investidores, que vislumbram a oportunidade de criar um empreendimento no local, como uma pousada, um restaurante ou uma agência de turismo.

Tudo isso faz com que as pessoas que habitam o local se sintam ameaçadas pelos impactos que as atividades turísticas podem causar, especialmente ao meio ambiente, conforme já se verificou em outras destinações turísticas onde a natureza é o principal produto turístico, como é o caso dos Lençóis Maranhenses.

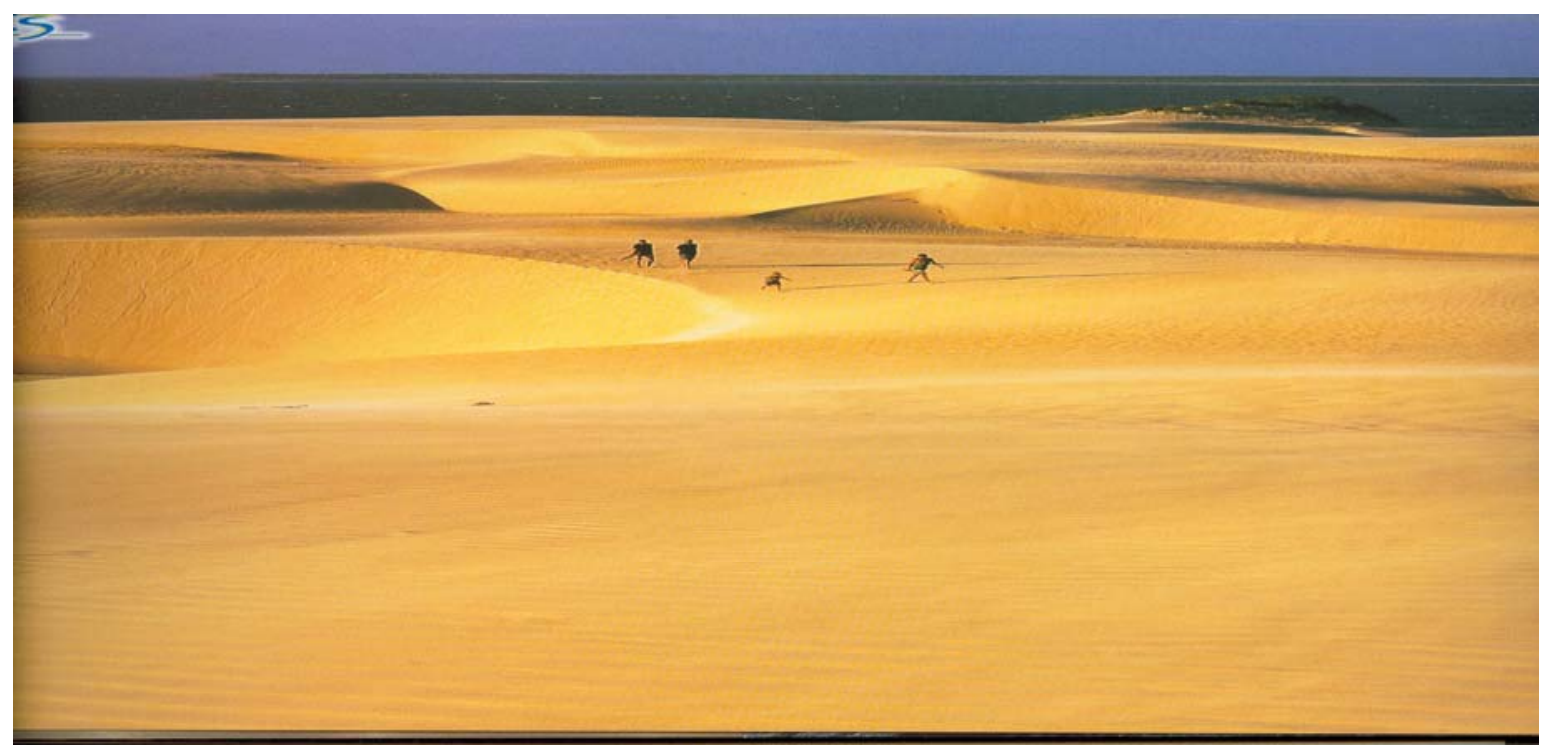

Figura 2 - Grandes Lençóis - por do sol (Maranhão - The Secret of Brazil - 2000)

${ }^{1}$ Ycarim Melgaço Barbosa - O Despertar do Turismo - Um olhar crítico sobre os Não-Lugares, série Turismo, Editora Aleph. 


\section{2 - Como chegar aos Lençóis Maranhenses?}

Saindo de São Luís, capital do Maranhão, para Barreirinhas, cidade considerada portal de entrada para os Lençóis Maranhenses, a viagem pode ser feita em 40 minutos, de avião (aeronave de pequeno porte), ou em três horas, de ônibus, e menos de três horas de carro próprio ou alugado nas agências de turismo em São Luís. São 260 quilômetros de estrada bem conservada, saindo pela BR 135 até Bacabeira (50 quilômetros), mais 10 quilômetros para a pequena cidade de Rosário e seguindo pela MA-402, são 200 quilômetros de estrada asfaltada, passando por Morros, trevo de Humberto de Campos, com lindas paisagens, até chegar em Barreirinhas. Nas proximidades já é possível perceber a aproximação com uma área de preservação ambiental, pelas várias placas espalhadas no percurso.

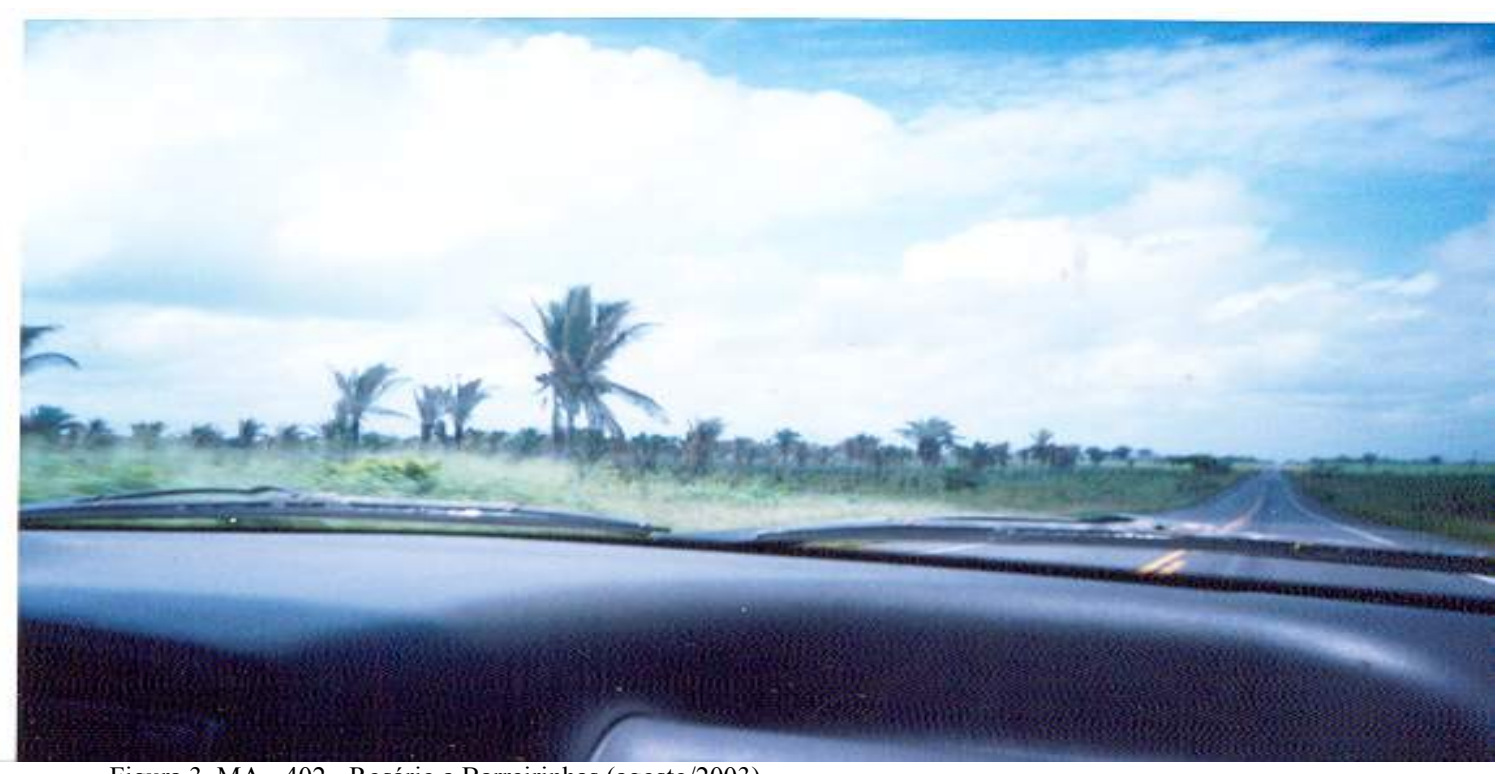

Figura 3. MA - 402 - Rosário a Barreirinhas (agosto/2003)

Com o asfaltamento dessa estrada o turismo iniciou uma nova fase no Maranhão. Os Lençóis Maranhenses passaram a fazer parte do roteiro turístico dos maranhenses, piauienses, cearenses e demais brasileiros de vários estados que antes não tinham coragem de enfrentar 200 quilômetros de estrada de chão. 


\section{3 - Barreirinhas}

Conhecida como portal dos Lençóis Maranhenses, Barreirinhas é descrita por quem a visita como "uma cidadezinha agradável, de gente muito educada" e já consolidada como um dos principais pólos turísticos do Maranhão e do Brasil.

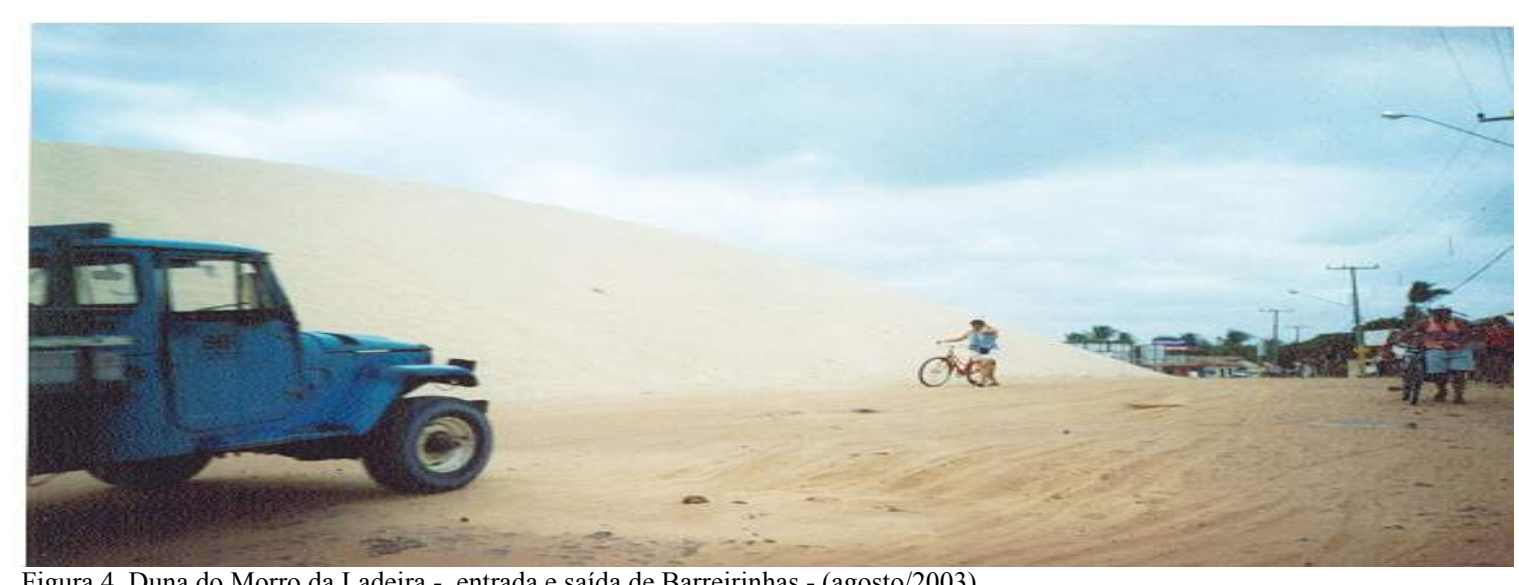

Figura 4. Duna do Morro da Ladeira - entrada e saída de Barreirinhas - (agosto/2003)

A cada dia que passa essa única entrada para o centro da cidade fica mais apertada. Até parece que a natureza aqui resolveu recepcionar os visitantes por meio dessa imensa duna no "Morro da Ladeira" - (dizem que no futuro essa passagem deixará de existir). O movimento dessa duna já obrigou as autoridades a planejarem uma outra porta de entrada da cidade e os moradores já se preparam para mudar de casa num futuro não muito distante. É para que se entenda que nesse lugar a mãe natureza deve ser respeitada.

Barreirinhas foi uma dessas cidades que ficam isoladas do mundo por muitos anos até que um fato marcante as tire do anonimato. Criada em 1930, somente em 1970 começa a aparecer, quando a Petrobrás ensaiou a prospecção de petróleo na região. Por ser a cidade mais desenvolvida da região, composta por inúmeras cidades de pequeno porte, como Humberto de Campos, Primeira Cruz, Urbano Santos, Paulino Neves e dezenas de povoados que vivem da pesca e da agricultura e vendem seus produtos na cidade e ao mesmo tempo compram os itens que necessitam para a sua subsistência. Por essas razões Barreirinhas foi beneficiada, e cada dia que passa é visível a sua liderança regional, principalmente com o advento do turismo. 
Até pouco tempo, ir de São Luís a Barreirinhas era uma aventura, levava-se de 8 a 10 horas em estrada de poeira no verão e lama no inverno. $\mathrm{O}$ asfaltamento da estrada foi comemorado como o grande sonho realizado pela sua população. $O$ tráfego continua complicado entre a cidade e as demais localidades. As vias estão sujeitas às condições sazonais: no alto inverno, ficam alagadas, no alto verão, a areia seca, torna-se muita fofa, só permitindo o tráfego por meio de veículos com tração nas quatro rodas. Entretanto, de Rosário a Barreirinhas a estrada é ótima, reduzindo o tempo da viagem para três horas.

A cidade recebeu o nome de Barreirinhas em virtude de haver muitas ladeiras e barreiras na região, quando não passava de um pequeno povoado. De acordo com os dados históricos de Barreirinhas, a sua emancipação foi em 29 de março de 1938, data comemorativa do aniversário da cidade. $\mathrm{O}$ município tem uma área de $2.477 \mathrm{k}^{2}$ e uma população de 39.360 habitantes, sendo 14.000 habitantes na área urbana e 25.360 distribuídos nos povoados da zona rural, muitos deles considerados pontos turísticos da região dos Lençóis Maranhenses, como Vassouras, Mandacaru, Atins, Caburé, Espadarte e Queimada dos Britos.

Barreirinhas tem algo que a difere de outras cidades. Quando o turista passa por essa duna gigante do Morro da Ladeira, ele sente que nessa cidade tudo tem um significado. "As cidades possuem signos, símbolos, representações que variam no tempo. Seus espaços não são meramente geográficos, por meio deles é possível pensar, criar, construir expectativas sobre as práticas sociais" (Salete Machado, - O Estrangeiro na cidade).

O município é considerado pela EMRATUR como um dos principais pólos turísticos do Maranhão, pois conta com atrativos turísticos que vão dos Lençóis Maranhenses ao Delta do Parnaíba ou Delta das Américas. Limita-se ao norte com o Oceano Atlântico, ao sul com Santa Quitéria e Santana do Maranhão, a leste com Paulino Neves e a oeste com Santo Amaro do Maranhão.

Além das paisagens mágicas dos Lençóis Maranhenses, o lugar tem o céu mais bonito do Brasil, sempre azul e um sol que brilha o dia todo, tornando esse deserto maranhense repleto de oásis, com dunas gigantes, lagoas de uma beleza extraordinária, de várias tonalidades, um lugar realmente mágico, onde ao amanhecer a natureza promove um verdadeiro espetáculo, - o primeiro do dia, pois no final da tarde, o por do sol se 
transforma num cenário que inspira poesia e quando chega a noite, se for de lua cheia, aí natureza desatina de vez.

Somando-se às belezas de suas dunas e lagoas em forma de enguias, que ao longo dos tempos vão tomando novas formas, a região oferece outros atrativos como belas praias em Vassouras, Atins e Caburé. Na foz do rio Preguiças em Atins, a natureza outra vez demonstra toda a sua magia, - o encontro do rio com o mar, os manguezais, os pássaros, uma praia que não tem tamanho, um mar calmo e transparente, dunas, um pescador na sua pequena embarcação retirando das águas o sustento de sua família. Tudo isso transforma o olhar do estrangeiro, que ao chegar nos Lençóis Maranhenses influenciado pela mídia que veicula as mais estonteantes imagens como produto turístico, com fins comerciais, acaba internalizando o sentimento de pertença. Ele sente que esse cenário também é seu e que precisa ser preservado.

De acordo com D’antona, “os Lençóis Maranhenses não são apenas um cartão postal, mas um tecido de práticas humanas, repleto de significados atribuídos por aqueles que ali vivem e manejam seus recursos, e por aqueles que para ali dirigem seus esforços e sentimentos".

\section{4 - O Rio Preguiças}

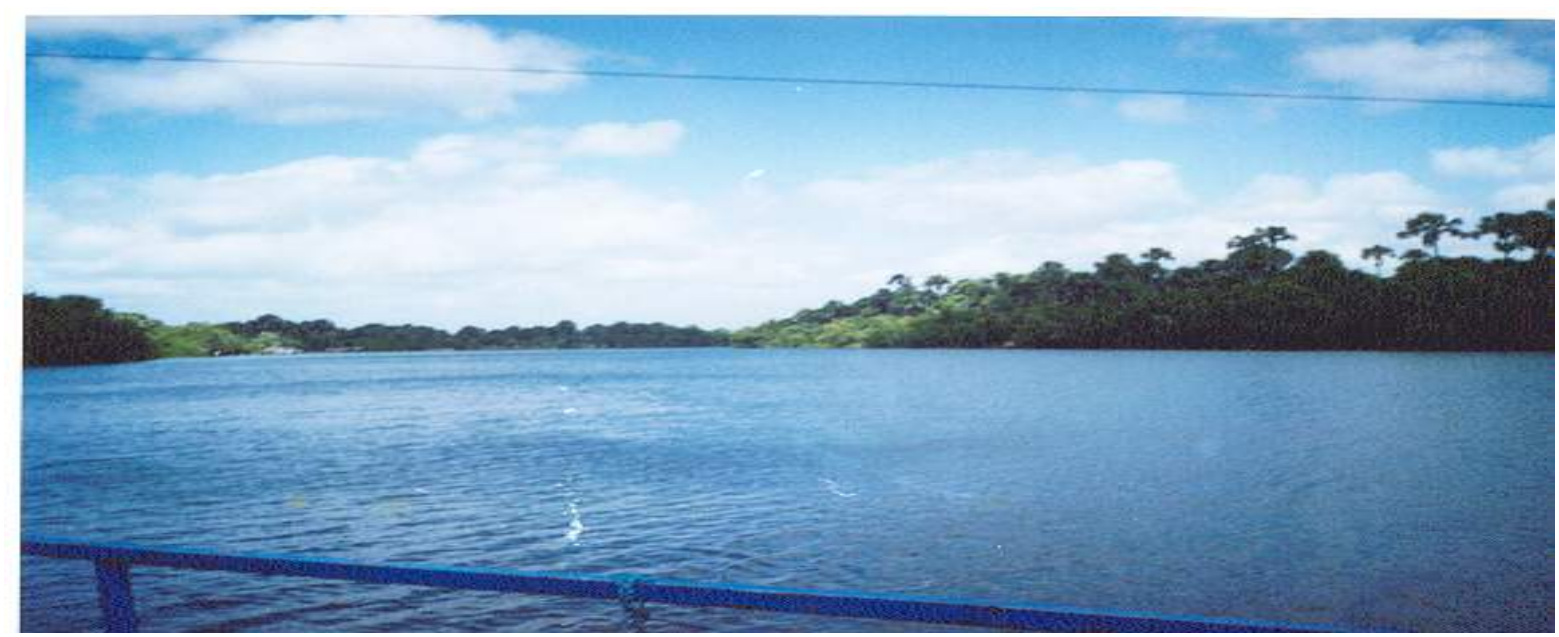

Figura 5 - Rio Preguiças (agosto/2003)

Se alguém perguntar ao nativo da região dos Lençóis Maranhenses, qual a importância do rio Preguiças para o local, ele responderá com firmeza - “o Preguiças é a nossa maior riqueza". 
O rio Preguiças é tão significativo para Barreirinhas, que embora seja desconhecida a data de penetração do homem no território, admite-se que tal fato ocorreu pelo rio Preguiças e por seus afluentes, que permitem o tráfego de pequenas embarcações. Conforme depoimentos de antigos moradores, a fixação do homem na região também recebeu influência do rio Preguiças e seus afluentes, pela fertilidade do solo, pelas pastagens e campos apropriados para a criação de gado e principalmente pela quantidade abundante de peixes, além do clima favorecido pelas águas do rio.

Outro fato importante que marcou o povoamento de Barreirinhas, nas margens do rio Preguiças, foi a construção de uma ponte, em 1849, sobre o rio Mocambo, permitindo a passagem de quem vinha por uma estrada que ligava Campo Maior no Piauí a Icatu no Maranhão, passando pela cidade de Brejo no território maranhense. (Prefeitura Municipal de Barreirinhas - Secretaria de Turismo e Meio Ambiente). Ainda, segundo dados da Prefeitura de Barreirinhas, há vestígios de povos antigos que povoaram a região, onde existia um engenho de cana-de-açúcar movido à roda d'água, localizado à margem do rio Achuí. (início do século XVIII).

O rio recebeu o nome Preguiças pela grande quantidade de preguiças que existiam nas suas margens, além da semelhança que as águas do rio tem com o bicho preguiça, por correrem preguiçosamente, tanto na enchente quanto na vazante, dando a impressão, muitas vezes, de estarem quase paradas. È um rio genuinamente maranhense, que tem a nascente no município de Anapurus e percorre 160 quilômetros, dando uma espécie de abraço em Barreirinhas, para desaguar no mar entre Atins e Caburé.

O movimento do rio Preguiças muda de direção de seis em seis horas - o mar determina o sentido da sua correnteza. Por este motivo é considerado muito perigoso, pois a mansidão das suas águas na superfície, se transforma em armadilha para os banhistas mais afoitos, que quando mergulham, são arrastados pelas fortes correntezas invisíveis, que já causaram muitas mortes.

Existem muitas lendas envolvendo o rio Preguiças, contadas pelos guias, que são ao mesmo tempo, condutores das embarcações, - lanchas voadeiras, com capacidade para 6 ou 8 pessoas. Enquanto levam os turistas para o passeio pelo rio, com destino ao PNLM, 
passando por Vassouras, Atins e Caburé, vão contando suas lendas. Nesse Passeio, onde tudo é acertado no início da viagem, o turista paga, em média, R \$ 40,00 pela passagem. Caso queira fazer a viagem fluvial em embarcações de linha, - lanchas com maior capacidade de passageiros, paga mais barato, mas perde muito tempo, pois esse tipo de embarcação leva em média 3 horas de viagem entre Barreirinhas e Caburé.

A aventura turística nos Lençóis Maranhenses iniciada pelo rio Preguiças deixa o turista em estado de graça logo na saída de Barreirinhas, quando o condutor da voadeira deixa o leito principal do rio, para ganhar tempo, toma um atalho, colocando o turista ainda mais em contato com a paisagem, composta de uma rica fauna e flora, manguezais e imensos buritizais.

Nas proximidades de Vassouras o rio Preguiças se multiplica, formando um verdadeiro trevo fluvial. E agora? Pergunta o turista ao condutor do barco, encantado com a paisagem, o manguezal enfeitado de guarás brancos e vermelhos, e confuso com a falta de sinalização, como se fosse possível haver placas no meio do rio indicando o caminho a seguir. É aí que as lendas começam a serem contadas pelo guia: “Olhem, se tomarmos essa direção (apontando para um dos braços do rio) vamos de encontro a um dos grandes mistérios do rio Preguiças. È comum, ao entardecer, ouvir-se tambores tocando sem parar e não adianta seguir em frente, pois nunca vamos alcançar as pessoas que tocam esses tambores, dizem que são mulheres - mãe-d'água" - diz emocionado o condutor da voadeira.

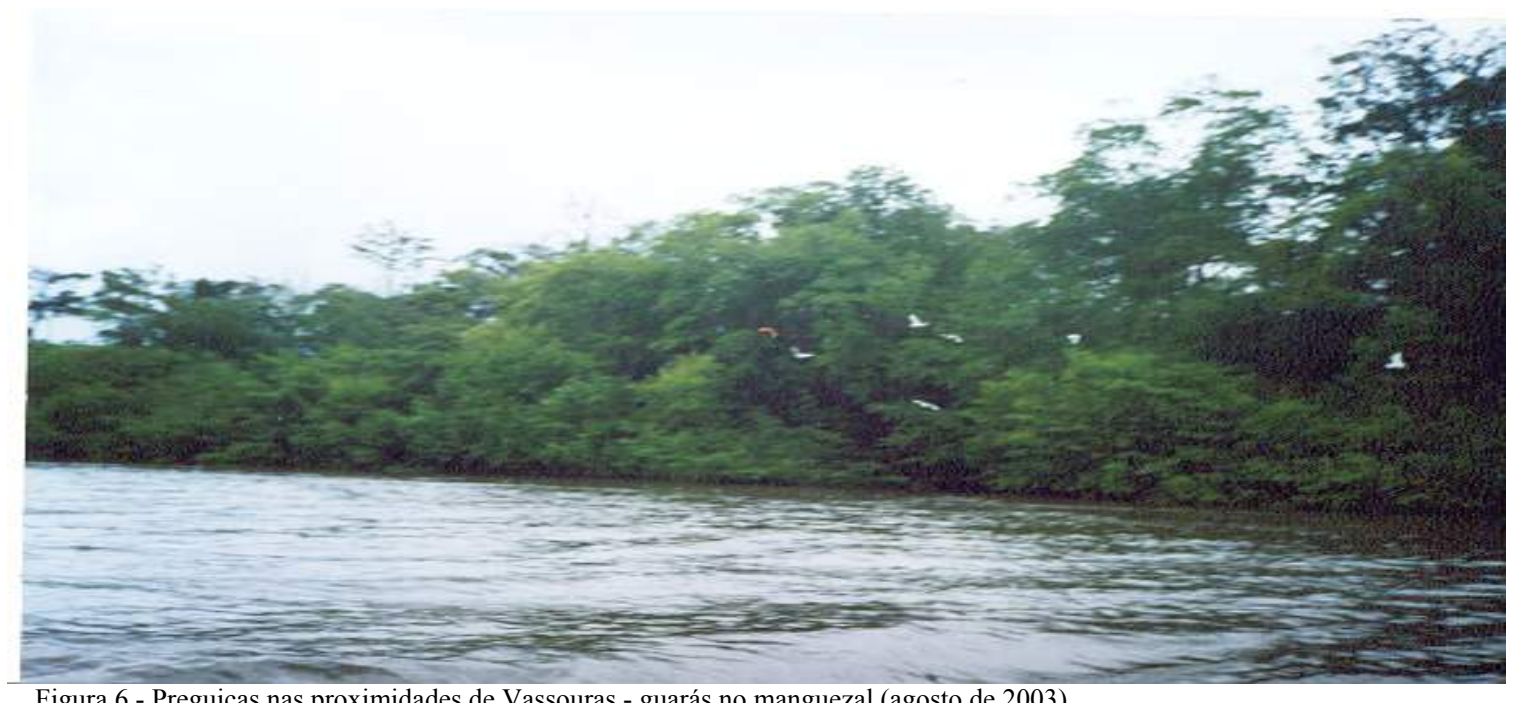

Figura 6 - Preguiças nas proximidades de Vassouras - guarás no manguezal (agosto de 2003) 


\section{5 - Vassouras}

Seguindo pelo rio, quando já é possível notar as águas do Preguiças se misturando com o mar, pela sua agitação, eis que surge de repente um clarão no manguezal, - é Vassouras, primeira parada, para os primeiros contatos dos turistas com os nativos do lugar, chamado "Pequenos Lençóis" e com as maravilhosas dunas e lagoas dos Lençóis Maranhenses. O guia vai logo informando: "Aqui, até o final de julho, início de agosto, era possível encontrar lagoas belíssimas, de águas cristalinas, mas agora (final de agosto) a parada aqui é só para contemplar as dunas e tomar uma água de coco”.

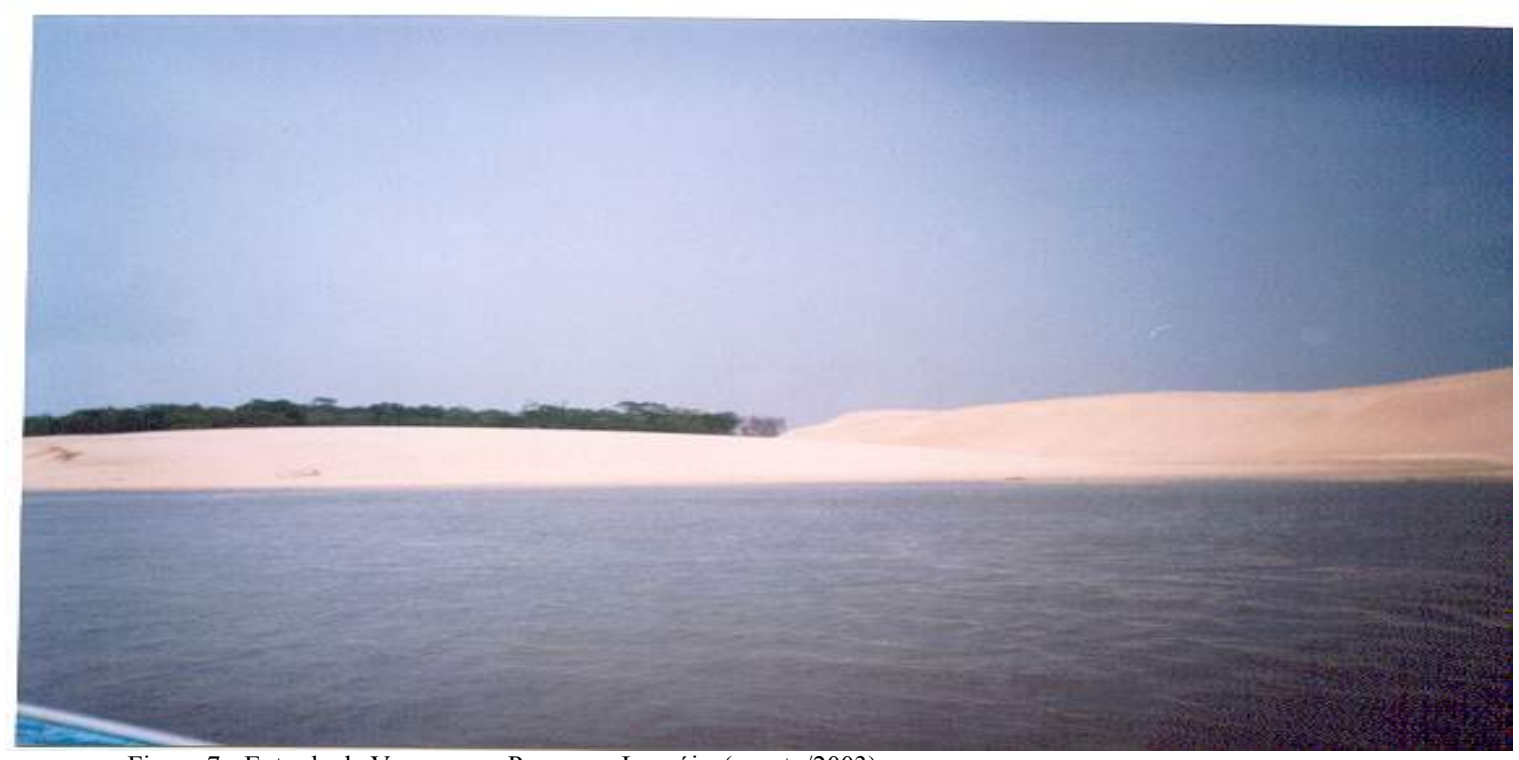

Figura 7 - Entrada de Vassouras - Pequenos Lençóis (agosto/2003)

Vassouras, região conhecida como Pequenos Lençóis é a primeira amostra da grandeza dos Lençóis Maranhenses. No local, observa-se, com espanto, a imensidão das dunas que chegam a 40 metros de altura. Lá embaixo vê-se uma casa de pescadores, de uma família que construiu uma cabana ao lado de outras do mesmo nível, logo na entrada, formando um pequeno núcleo comercial para recepcionar os turistas que visitam o lugar, dispondo de peças diversas de artesanato, bebidas, refrigerantes, salgadinhos, coco da praia. A dona da barraca diz: "aqui passamos o dia trabalhando, ganhando o sustento da família e quando anoitece vamos para casa. Aqui são filhos e sobrinhos, - apontando para 
quase uma dezena de meninos e meninas, na faixa etária dos cinco aos quinze anos". Ana Cléa de dez anos diz que é "guia de turista", - "ganho de dez a cinco reais de cada turista e entrego o dinheiro para minha mãe comprar café, farinha e meus cadernos". Segue falando: "eu mostro as dunas e digo para os turistas que daqui a gente já vê o mar".

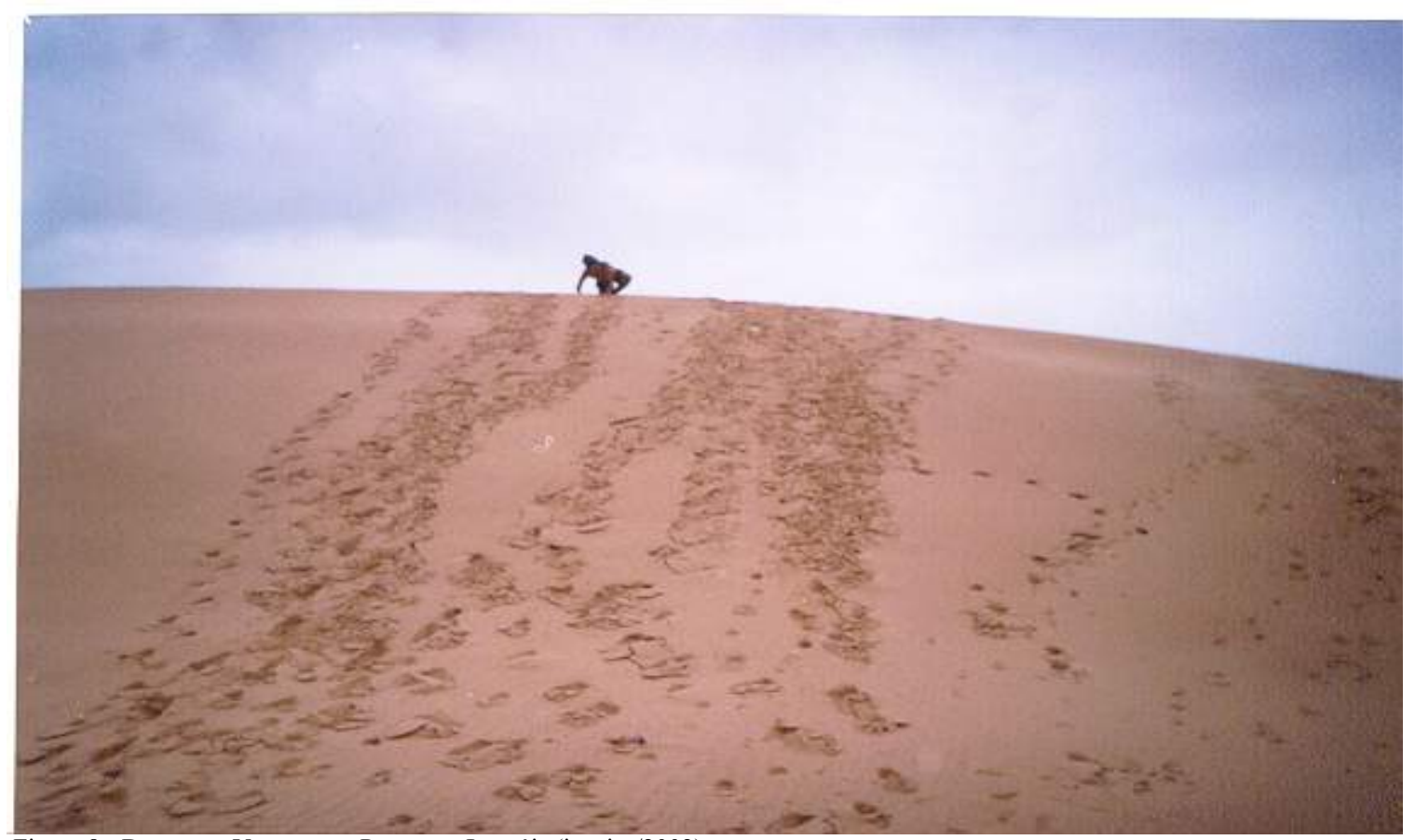

Figura 8 - Dunas em Vassouras - Pequenos Lençóis (janeiro/2002)

Observa-se que na região dos Lençóis, a exemplo do que acontece nas grandes cidades, as crianças participam ativamente da construção da renda familiar, quer seja, trabalhando na lavoura, no artesanato, ou mesmo como "guia de turismo" em Vassouras ou Mandacaru, como é o caso de Ana Cléa.

\section{6 - Farol de Mandacaru}

Mandacaru é a segunda atração turística seguindo pelo rio Preguiças. Observa-se a mesma situação ocorrida em Vassouras na chegada em Mandacaru. Muitas crianças se aproximam do barco e um vai logo mostrando suas qualidades de guia de turismo. "Aqui é o Farol de Mandacaru, o farol tem 35 metros, essa casa aqui do lado foi onde a Ana Maria Braga e Louro José falaram naquele alto-falante". Se não fosse interrompido continuaria 
falando por muito tempo, tudo decorado, como acontece nas demais destinações turísticas do Brasil. Quando alguém interrompe o discurso, o garotinho começa tudo de novo.

Mandacaru é uma pequena vila de pescadores que tem o Farol Preguiças, mais conhecido como "Farol de Mandacaru" como atração turística. O farol foi construído em 1940, mas só foi inaugurado em 1944 pelo Almirante Moraes Rego. O farol, com 45 metros de altura, 160 degraus foi construído com o objetivo de guiar os navegadores, livrá-los dos perigos da região, onde o mar apresenta pouca profundidade, gerando muitos acidentes.

Do farol tem-se uma vista panorâmica que combina com a magia dos Lençóis Maranhenses, onde é possível ver os povoados de Mandacaru e Atins ${ }^{1}$, outra vila de pescadores que fica de frente para o foz do rio Preguiças.

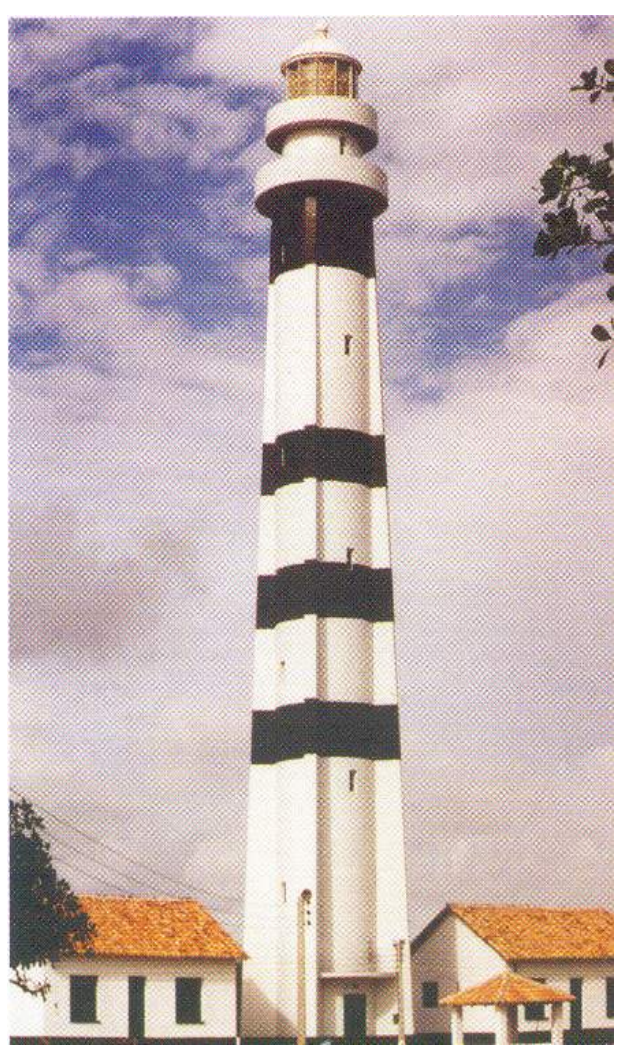

Figura 9- Farol de Mandacaru

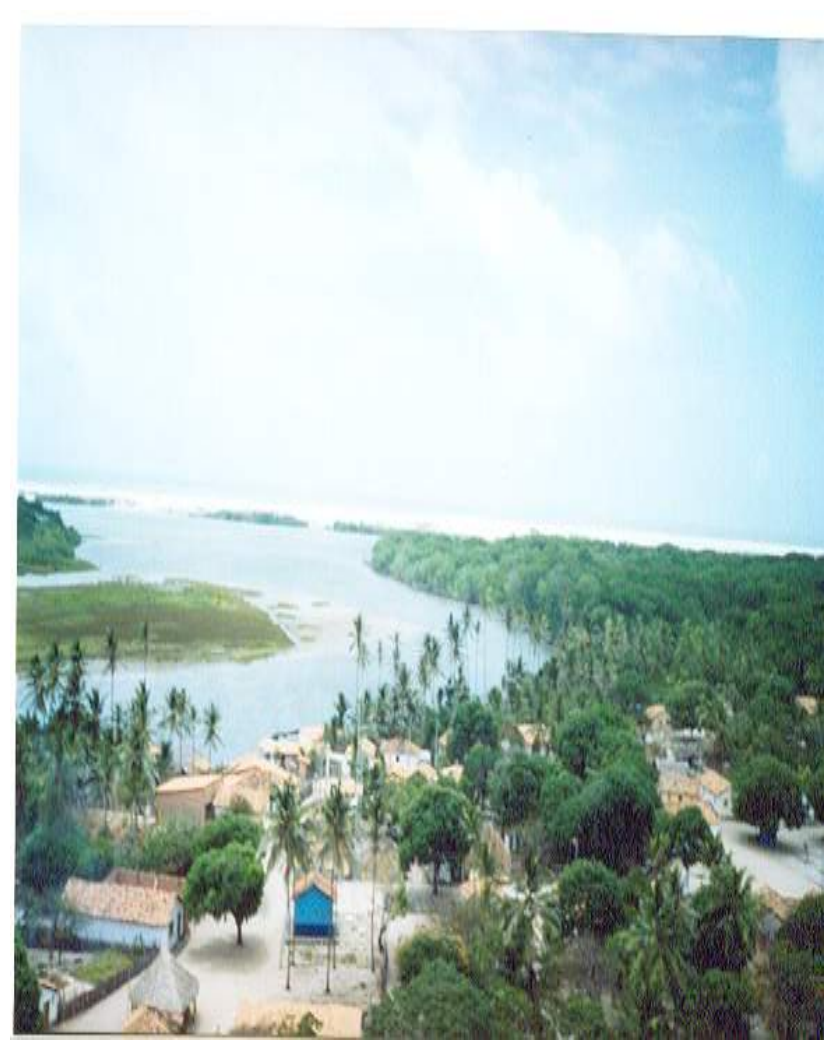

Figura 10 - Vila de Mandacaru - vista panorâmica

1. Atins - vila de pescadores, onde fica uma sede do PNLM 


\section{7 - Caburé}

A exemplo do rio Preguiças, Caburé recebeu essa denominação em virtude da quantidade de aves com esse nome que existiam na ilha. O lugar é a tradução da beleza, o Preguiças na frente e o Atlântico nos fundos. Caburé fica bem próximo da foz do rio Preguiças. Tem uma população nômade, por conta dos fortes ventos que sobram do mar, transformando constantemente o lugar e obrigando os moradores a abandonar suas casas no fim do inverno. O retorno acontece só no ano seguinte, considerando que existem somente duas estações na região - inverno e verão.

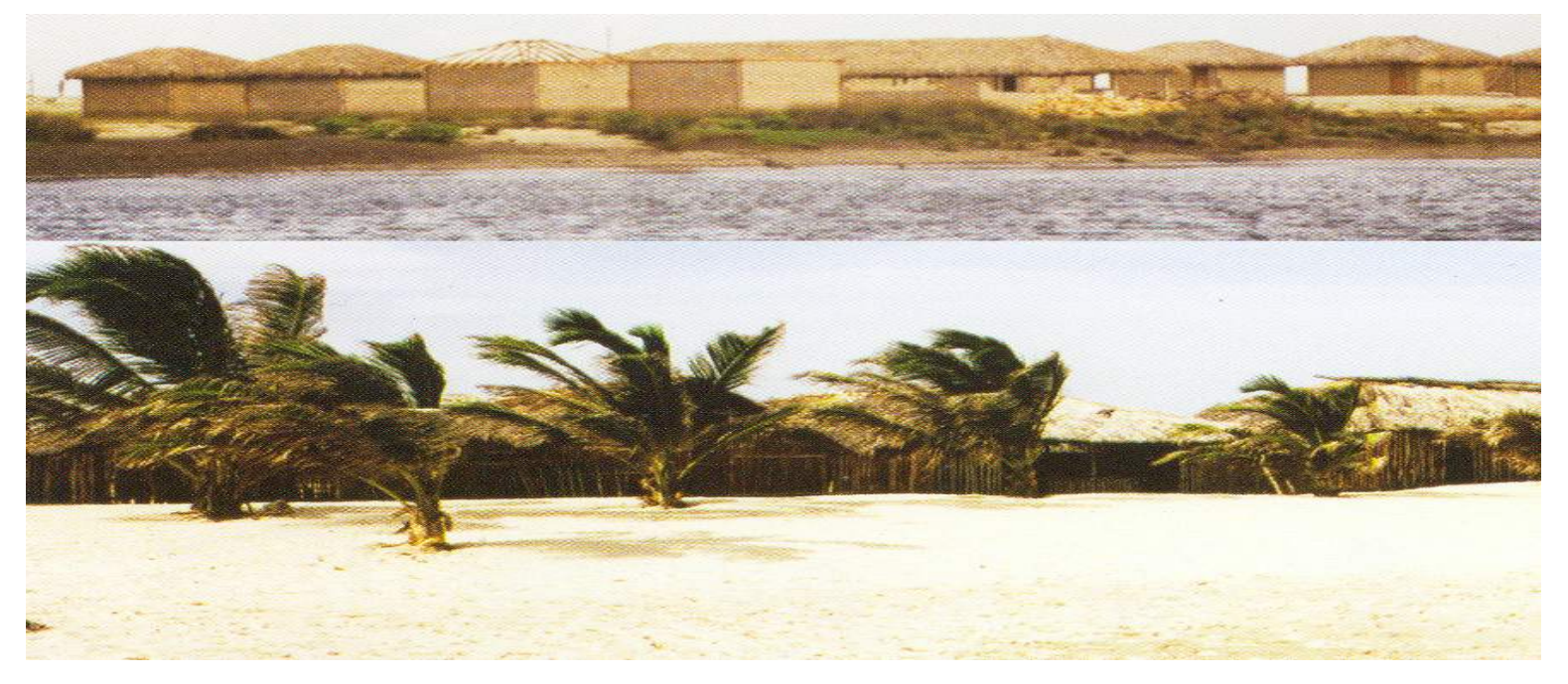

Figura 11 - Caburé (foto D'antona)

Assim como outros povoados da região como Vassouras, Moitas e Morro do Boi, o lugar tem uma semelhança com certas tribos indígenas, com suas cabanas feitas de madeira e palha de buriti. Os habitantes geralmente são de Barreirinhas ou de outras localidades, especialmente de Tapuio e Laranjeiras.

O lugar funciona como ponto final do passeio pelo rio Preguiças, especialmente, para o almoço. No final de agosto o lugar parece abandonado, as cabanas são invadidas pelas dunas de areias brancas como açúcar, empurradas pelos fortes ventos que vem do mar, restando pouca coisa funcionando. Entretanto, a Cabana do Paulo está pronta para um atendimento de primeira qualidade - um cardápio onde há peixe para todos os gostos. 
Depois, vale a pena deitar numa rede, sentir por alguns momentos o que significa "qualidade de vida", não esquecendo de conversar com o Paulo e saber como e quando ele chegou em Caburé.

Entre Caburé e Atins localiza-se a foz do Rio Preguiças. O cenário é composto pelo rio, o mar, uma imensa praia virgem, a vila de Atins, onde se inicia o Parque dos Lençóis Maranhenses e o manguezal. O guia descreve o lugar da seguinte forma: - "Este lugar é o mais bonito da região dos Lençóis, não há turista que não fique enfeitiçado quando chega aqui".

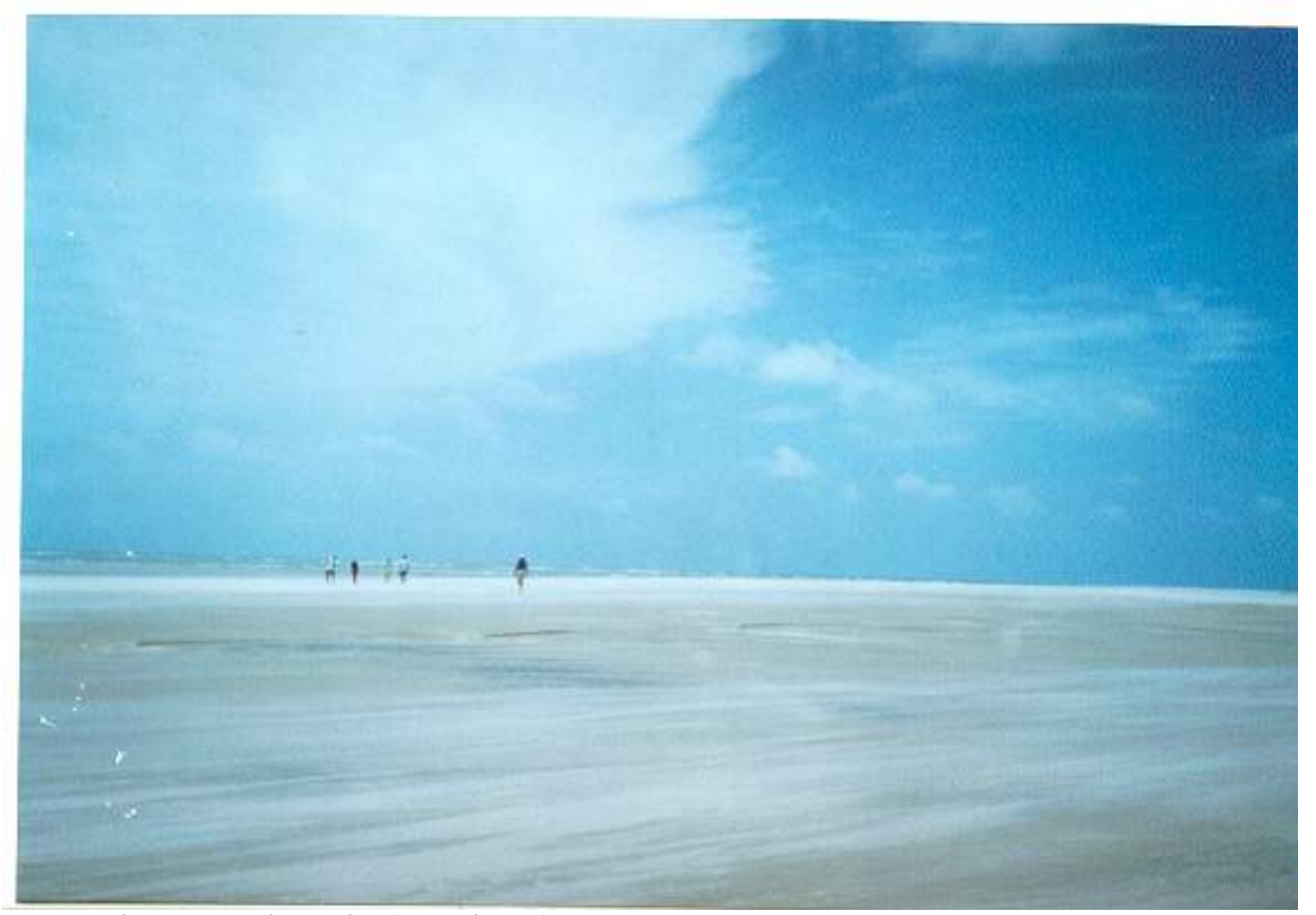

Figura 12 - Foz do Preguiças (agosto de 2003)

Em seguida, é só tomar um banho no Atlântico, entrar na voadeira e retornar à Barreirinhas, tendo concluído um dos passeios imperdíveis nos Lençóis Maranhenses, que, normalmente, dura um dia, via rio Preguiças. 


\section{8 - As Lagoas dos Grandes Lençóis}

O segundo passeio, agora por via terrestre, tem a mesma duração do primeiro, via rio Preguiças. Saída às 9 horas e retorno no final da tarde. A finalidade é conhecer as maravilhosas lagoas dos Grandes Lençóis. Para esse passeio o turista precisa tomar certas providências, tais como: comprar água, refrigerante ou suco, biscoito ou qualquer outro tipo de lanche. É necessário levar também protetor solar. Nas dunas e lagoas dos Grandes Lençóis não há infra-estrutura alguma, não existem pousadas nem restaurantes, é só dunas, sol e lindas lagoas.

O transporte é uma toyota $4 \times 4$, que leva geralmente de seis a sete pessoas, sendo uma na cabine e seis na carroceria com banco de madeira, bastante desconfortável. Logo na saída de Barreirinhas é precisa atravessar o rio Preguiças, - numa ponte móvel que recebe o nome de pontão.

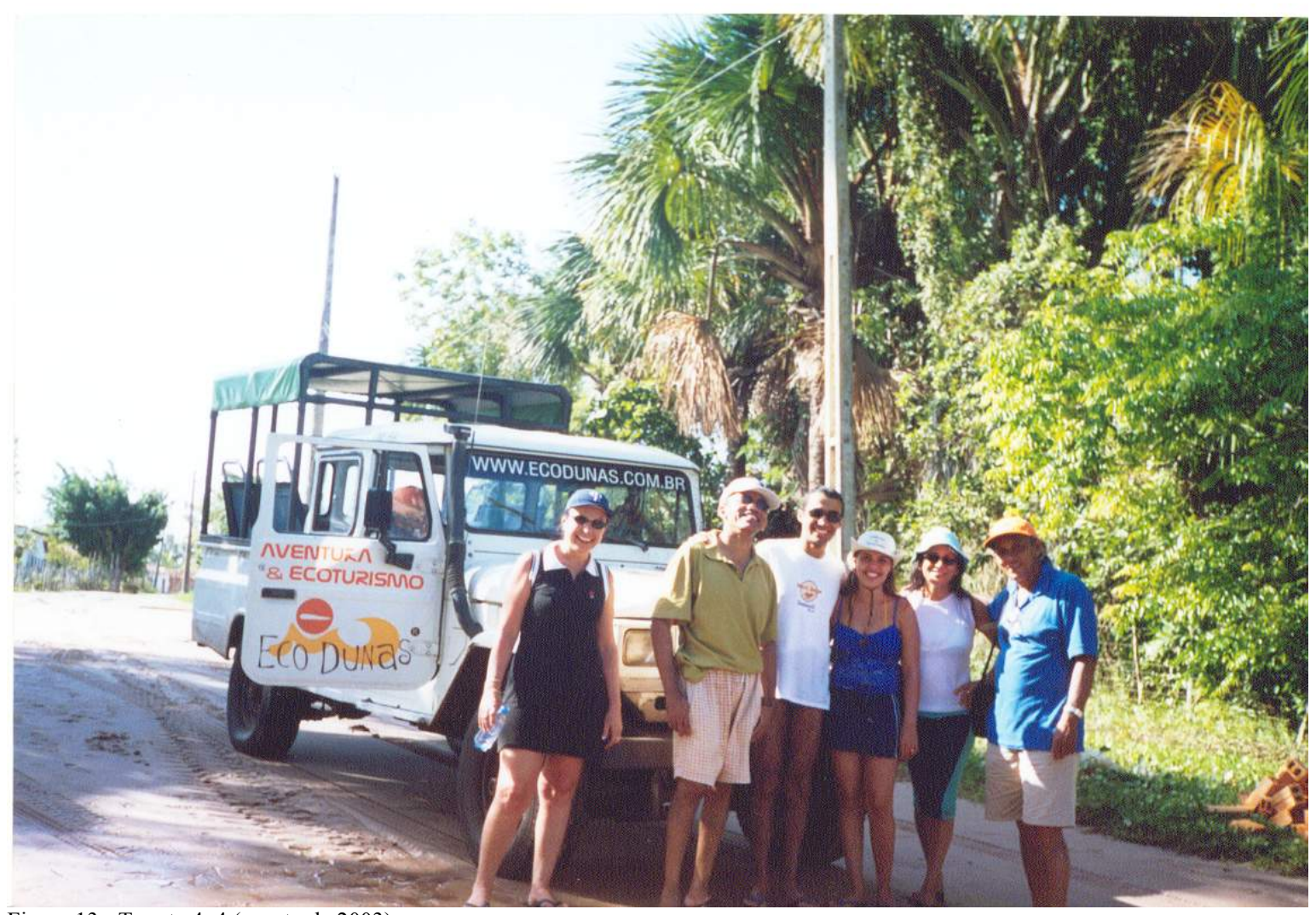

Figura 13 - Toyota $4 \times 4$ (agosto de 2003) 
A estrada é um verdadeiro banco de areia, com uma bitola que somente um piloto experiente é capaz de conduzir o veículo. Tem trechos do percurso que é preciso aceleração máxima e tem-se a impressão que o carro vai sair da bitola e chocar-se com as cercas de madeira, das pequenas propriedades com plantações de mandioca e muitos cajueiros, - uma das riquezas do lugar. Durante a viagem ouve-se com freqüência os gritos dos turistas - "segura peão", como se estivessem montados em touros ou cavalos bravos.

Existem também alguns riachos, difícil de acreditar que o carro vai passar, isso, em pleno mês de agosto, período que já não chove na região. As chuvas acontecem geralmente no período de dezembro a junho. A melhor época para conhecer as lagoas é entre o início de junho e final de agosto, período em que as lagoas estão cheias e o tempo é muito bom.

Depois de uma hora de viagem, surgem as dunas. Encontra-se numa árvore retorcida, vegetação de cerrado, uma placa sinalizando que no pé daquela montanha de areia branca inicia-se uma viagem por um lugar mágico chamado "Parque Nacional dos Lençóis Maranhenses". É a área chamada de "Grandes Lençóis". Nesse ponto ficam as toyotas e seus motoristas.

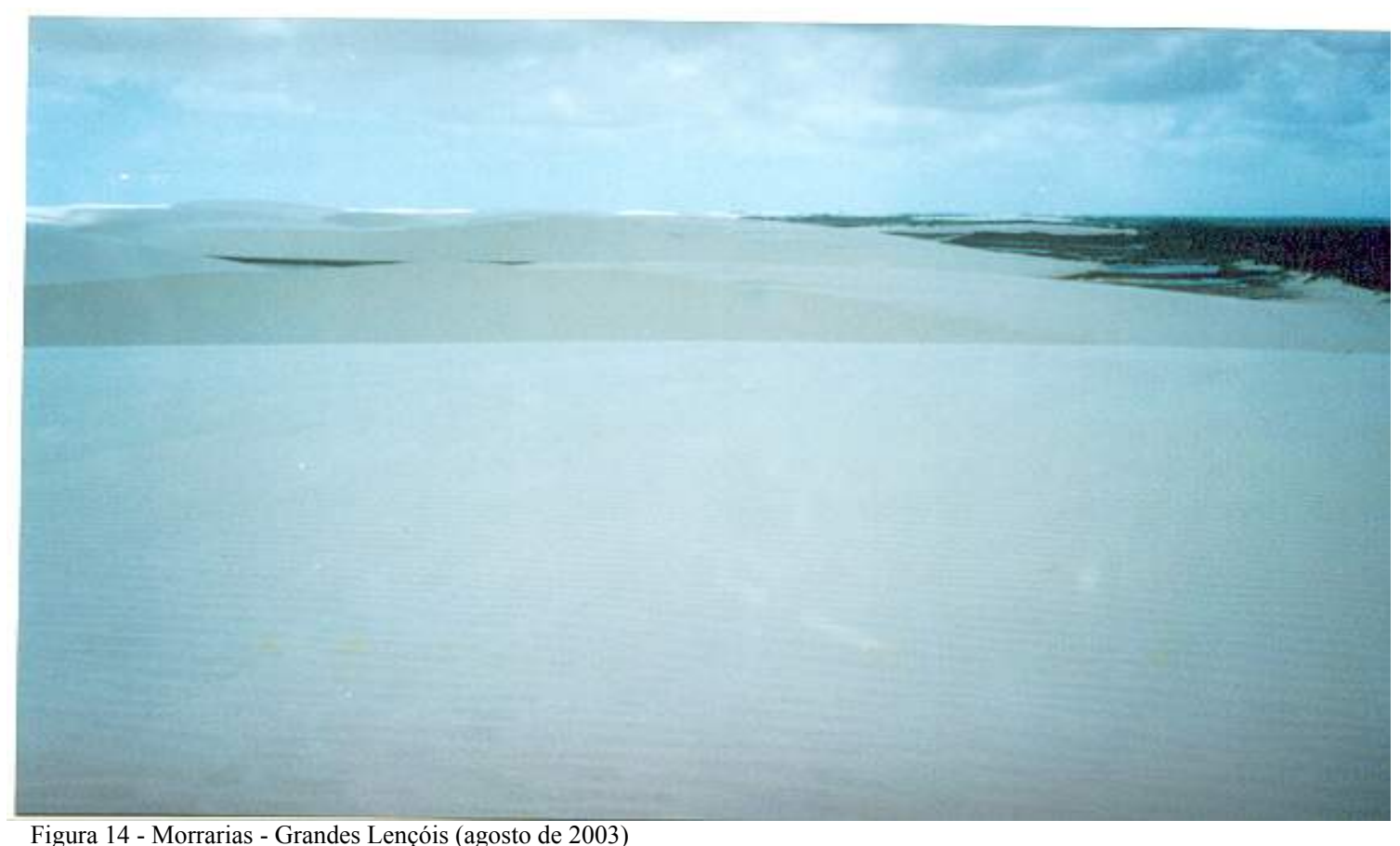

Figura 14 - Morrarias - Grandes Lençóis (agosto de 2003) 
A subida da montanha de areias brancas é de tirar o fôlego de qualquer atleta. Os turistas seguem o guia, que leva nas costas um isopor com garrafas de água, gelo e os lanches, cujos recipientes são depositados no mesmo isopor depois de consumidos.

Não é permitido jogar um copo plástico ou qualquer outra coisa nas areias ou nas margens das lagoas, onde o guia finca o seu enorme guarda-sol para se proteger, enquanto os turistas não resistem a um banho refrescante nas águas cristalinas da primeira lagoa, onde se ver dezenas de peixinhos coloridos. Isso é uma amostra do que o turista vai encontrar pela frente nas próximas 6 horas, dunas de até 40 metros de alturas - morrarias (como dizem os nativos) e lagoas de varias formas e tonalidades.

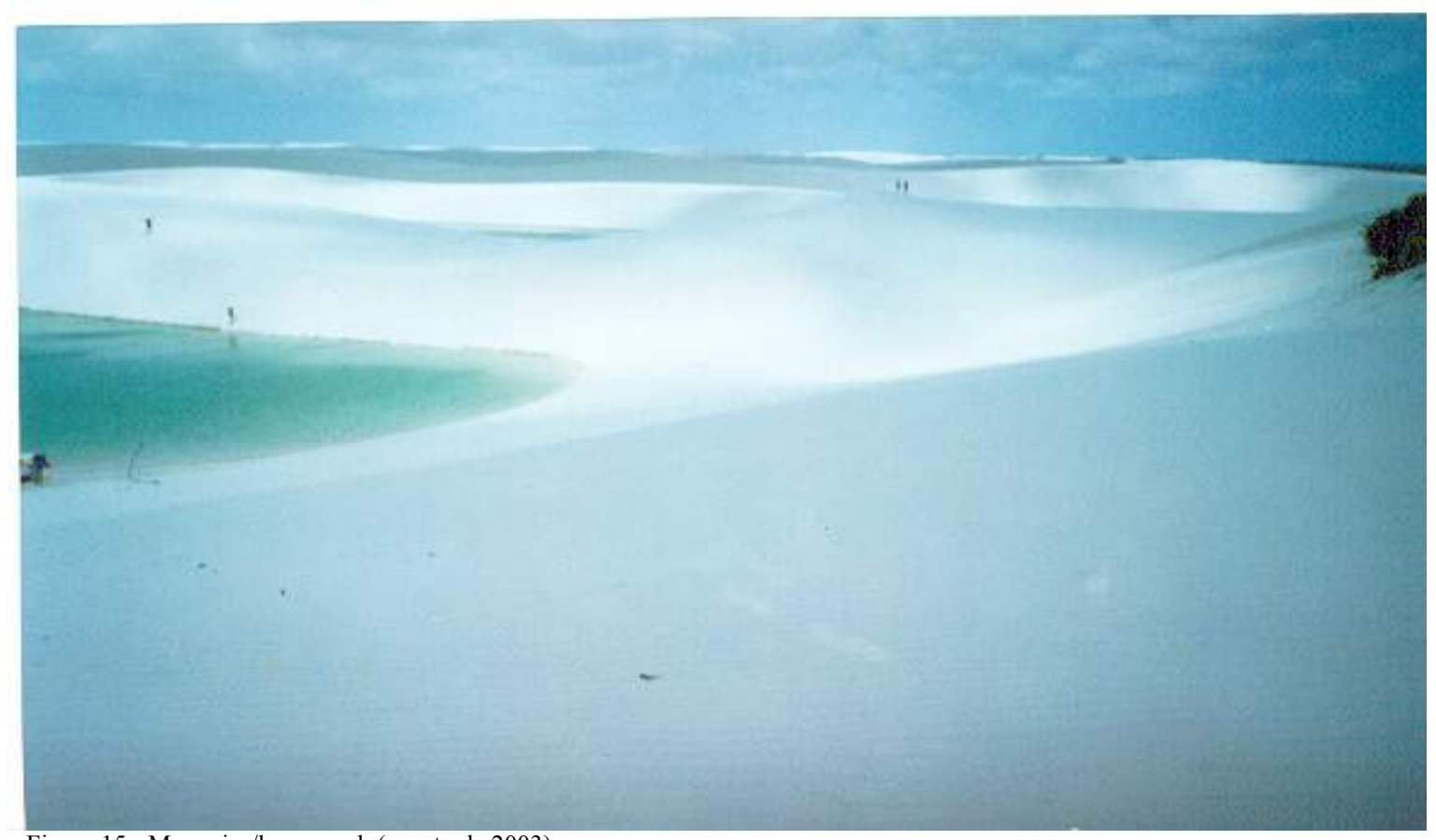

Figura 15 - Morrarias/lagoa azul (agosto de 2003)

No final da imensa duna já é possível contemplar toda a magia dos Lençóis Maranhenses. O sol é intenso, o vento faz um barulho que parece anunciar uma tempestade, os grupos de turistas vão surgindo e aos gritos, deslumbrados, vão falando coisas como: "nunca imaginei que fosse tão bonito assim, "fantástico, isso é um paraíso" e correm para as lagoas coloridas do PNLM 


\subsection{1- Lagoa Azul}

A primeira lagoa dos Grandes Lençóis é a mais bonita de todas - tem o nome de Lagoa Azul. O cenário é indescritível, não é possível, especialmente para quem não tem a poesia nas veias, encontrar palavras para dar significados a tanta mistura de azul do céu com o branco das areias, dando cores às águas da lagoa que mudam de tonalidade, ora verde, ora azul, é a natureza brincando com a imaginação dos turistas.

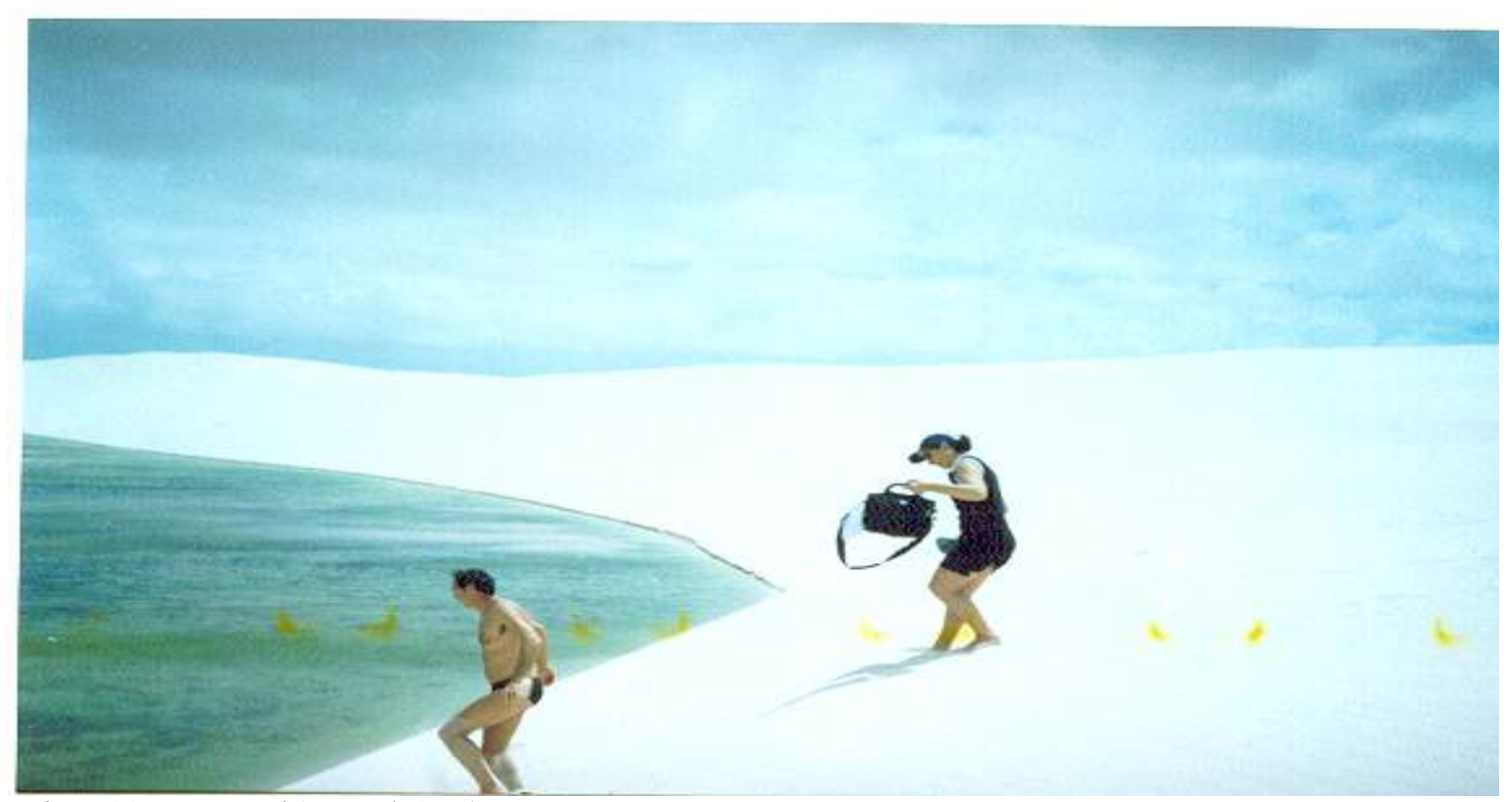

Figura 16 - Lagoa Azul (agosto de 2003)

Esse cenário é mutável. $\mathrm{O}$ vento forte que bate nessas enormes paredes com o passar do tempo vai transformando o formato da lagoa, às vezes, essa grande piscina vai se confundindo com uma enorme enguia, as extremidades também podem ser transformadas em duas ou três outras lagoas.

Depois de um banho demorado, é preciso o guia avisar que já é hora de seguir adiante, para conhecer outras lagoas, escalar novas dunas.

Ao retomar o passeio, o guia orienta os turistas sobre os melhores caminhos para se chegar a outras lagoas, o que é impossível para um grupo de pessoas que não conhece o local e facilmente, sem o guia, se perde pelo imenso deserto. Vão surgindo morrarias e mais morrarias, dunas gigantes de areias brancas e tão finas que facilita o trabalho do 
vento forte que sopra sem parar e que tem a incumbência de transportá-las para outros lugares, dando vida e movimento a um lugar que parece parado, na imensidão de um deserto silencioso, mas que por um capricho da natureza se transforma, revelando novos cenários, como se houvesse aqui, onde se ouve apenas o barulho do vento, um exército de profissionais, artistas, escultores, sempre renovando a paisagem.

\subsection{2 - Lagoa da lua}

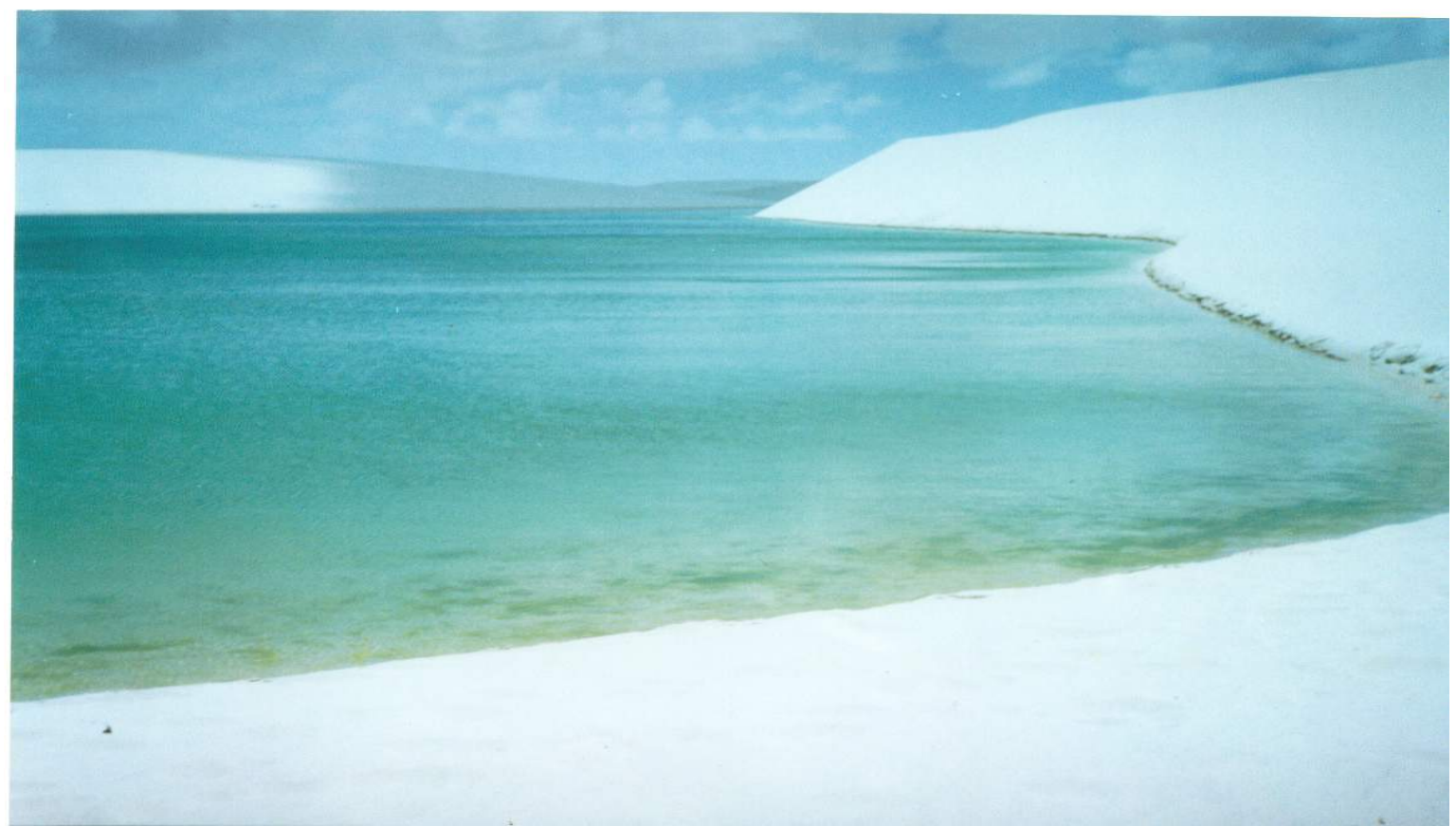

Figura 17 - Lagoa da Lua (agosto de 2003)

Diante dessa lagoa a turista enquanto era filmada por seu esposo e preparava o seu documentário fez o seu seguinte pronunciamento: - "Deus delegou muitas coisas importantes ao homem, tais como: construir açudes, represas, lagos artificiais e até mesmo mudar o curso de um rio, mas essa obra Ele não permitiu que ninguém tocasse, Ele mesmo a construiu".

Além dessa lagoa existem muitas outras, o guia avisa que a mais distante é a Lagoa da Esperança que fica na extremidade do PNLM, a 40 quilômetros de Barreirinhas. Uma lagoa que não pode deixar de ser visitada, segundo informações do guia é a Lagoa do Peixe que juntamente com a Lagoa Azul e a Lagoa Bonita são as preferidas dos turistas e dos nativos. 


\subsection{3 - Lagoa do Peixe}

Cada lagoa tem um nome, um significado. O guia avisa que estamos chegando na Lagoa do Peixe, onde se tem a impressão que há milhares de anos foi aberto nesse lugar um grande açude para reter esse líquido tão precioso que é a água. As paredes aqui são enormes. Difícil acreditar que a natureza sozinha realizou essa obra. Diferente das outras, essa lagoa requer um pouco mais de cuidado, por parte dos turistas, especialmente os que não sabem nadar, pois logo que se entra na água já é possível perceber a profundidade dessa lagoa que recebe o nome de "Lagoa do Peixe", pela quantidade de peixes que nela existe.

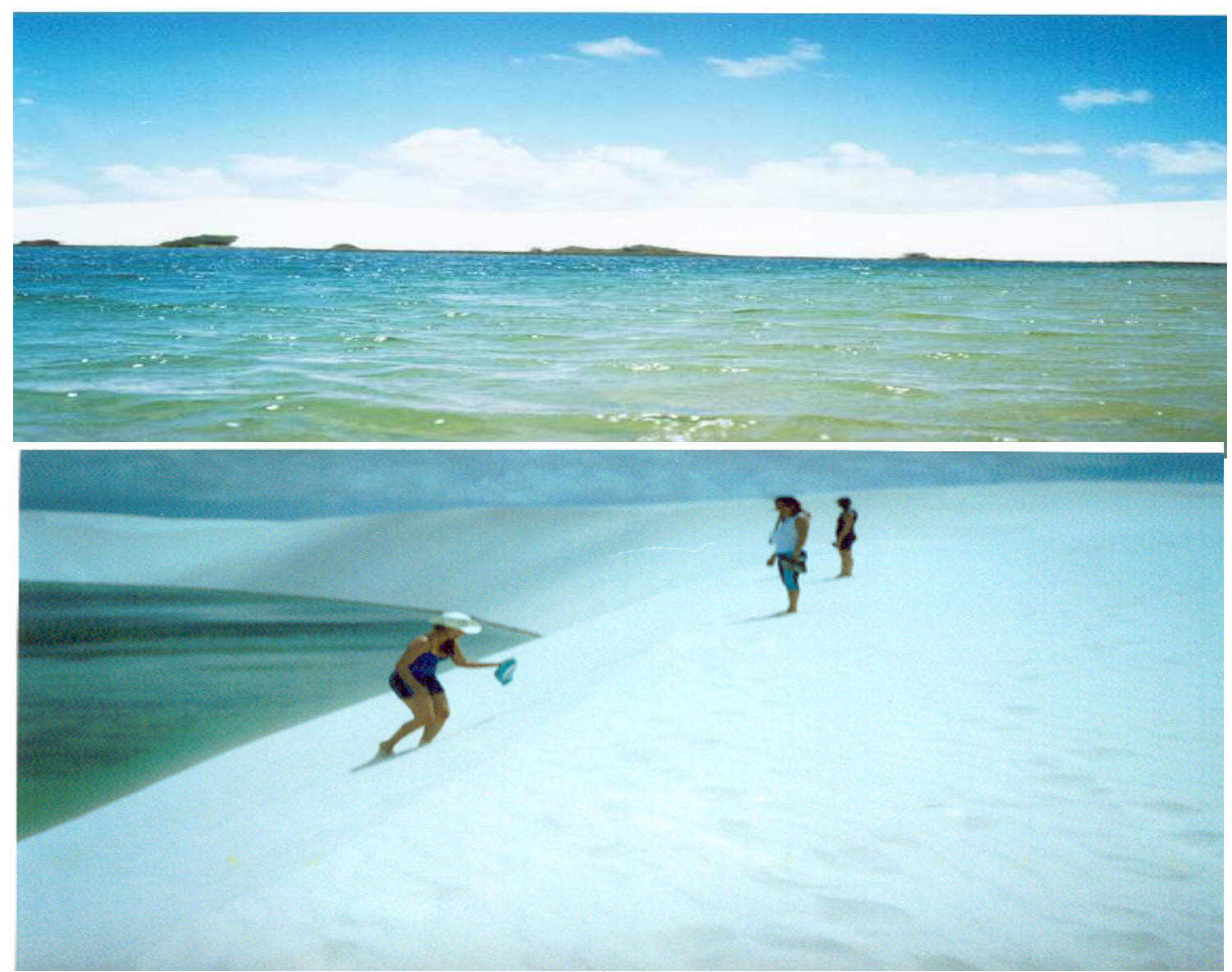

Figura 18 - Lagoa do Peixe (agosto de 2003)

O passeio pelas dunas e lagoas dos Grandes Lençóis termina na Lagoa do Peixe. É hora de retornar a Barreirinhas e procurar um restaurante para matar a fone, pois nessas cinco ou seis horas de puro êxtase, não é possível ingerir mais do que água, suco e um pequeno lanche. 
Na saída, o guia informa que para percorrer todo o parque a pé e chegar até ao mar, leva em torno de 8 a 10 horas e deve-se está acompanhado por um guia que conheça bem o Parque Nacional dos Lençóis Maranhenses.

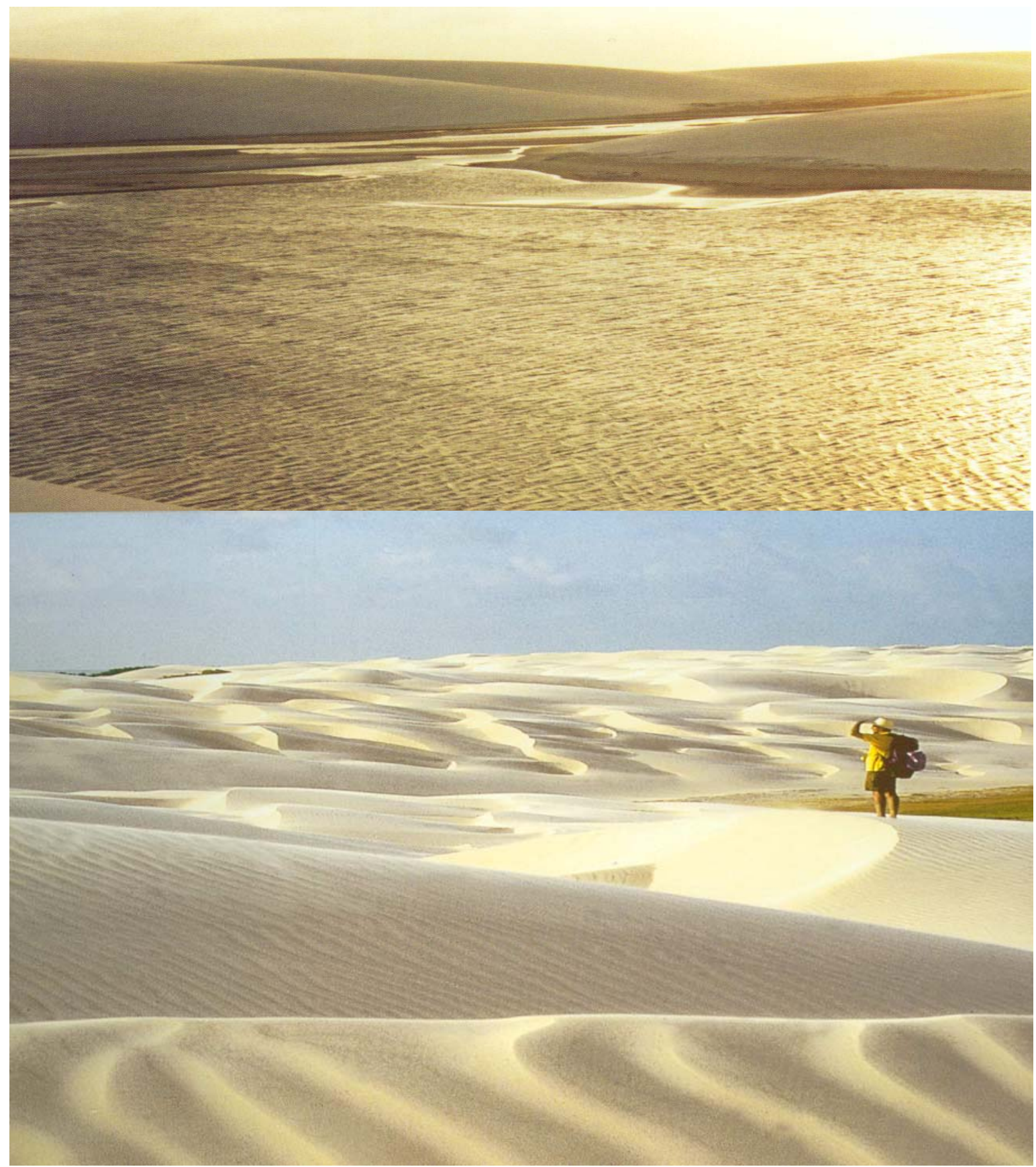

Figura 19 - Grandes Lençóis - um mundo mágico

Fotos: Maranhão - O Segredo do Brasil (2000) 


\section{9 - Características do Parque Nacional dos Lençóis Maranhenses}

Em 02 de junho de 1981 pelo decreto $n^{\circ}$ 86.060, foi criado o Parque Nacional dos Lençóis Maranhenses - PNLM, com o objetivo de preservação de ecossistemas, educação ambiental e visitação pública.

Conforme dados do Instituto Brasileiro do Meio Ambiente e dos Recursos Naturais Renováveis - IBAMA, técnicos do Projeto RADAMBRASIL, observaram a região e considerando ser o único deserto brasileiro cheio de água por metade do ano, sentiram a necessidade de preservação do local.

O PNLM possui uma área de 155.000 ha e 70 quilômetros de praia. O Parque dos Lençóis está localizado no Maranhão, abrangendo os municípios de Barreirinhas, Humberto de Campos e Primeira Cruz.

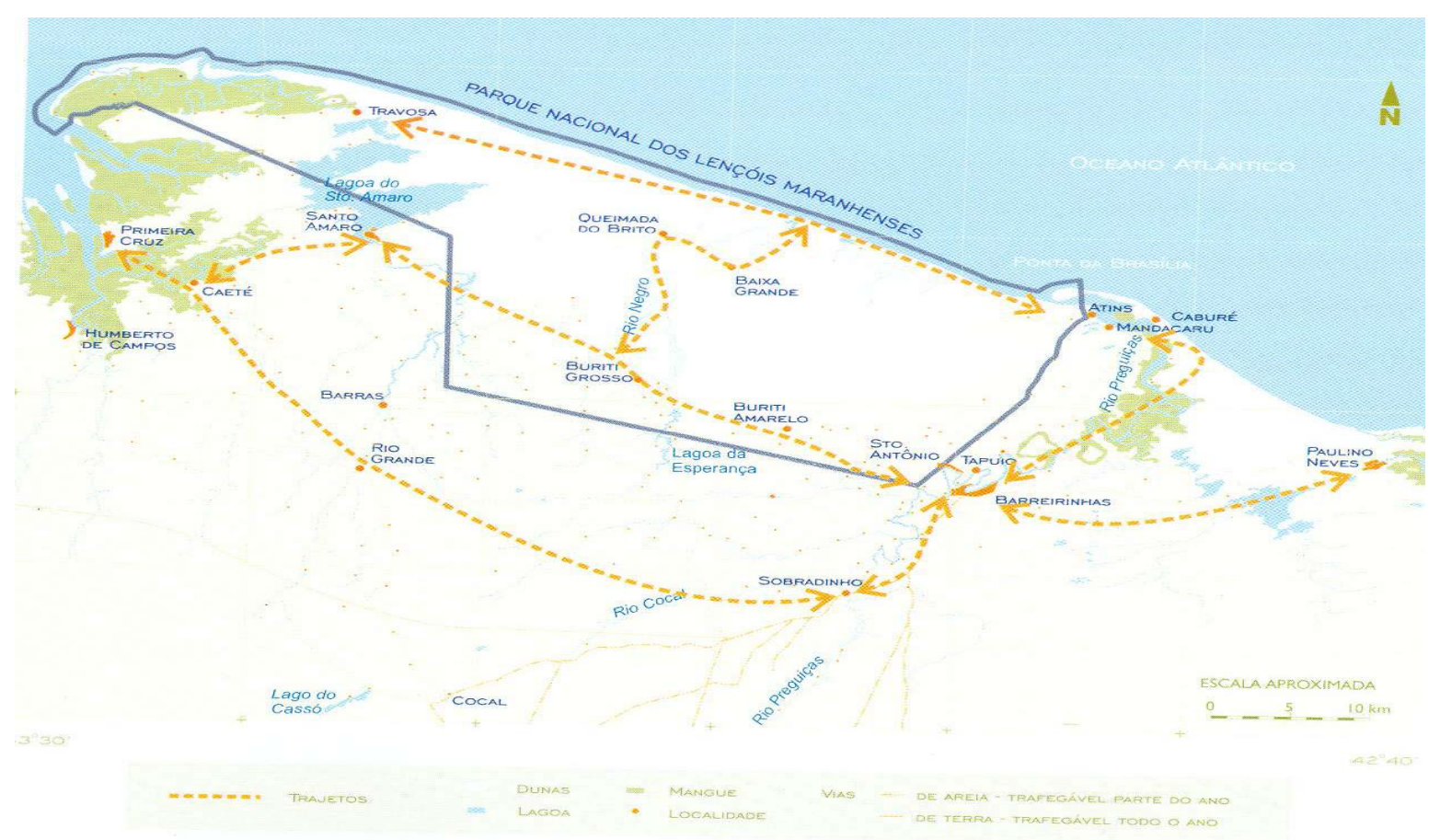

Figura 20 - Mapa do PNLM (IBAMA) 
Conforme já vimos o acesso ao PNLM é feito tanto por terra como também pelo rio Preguiças a partir de Barreirinhas. A transformação do local em área de preservação ambiental foi fundamental, pois a preservação de um ecossistema único composto de dunas, mangues e restinga, é muito importante, apesar da frágil estrutura do IBAMA, com capacidade mínima para fiscalizar tamanha área. No momento o órgão possui 6 funcionários que atuam dentro do Parque dos Lençóis, orientando os turistas para não jogarem lixo nas proximidades das lagoas e conscientizando os condutores dos veículos que transportam os turistas a não transgredirem a lei que proíbe subir as dunas de carro, pela fragilidade do ecossistema. O IBAMA para realizar suas tarefas na região conta ainda com 4 fiscais, um barco para pesquisa e fiscalização, três lanchas, (uma voadeira) e um jeep.

O Parque dos Lençóis possui um relevo com as seguintes característica: a Oeste predominam as "rias" (vales de rios afogados), com formação de praias, manguezais, dunas, restingas e pequenas falésias: à leste do rio Piriá predominam as formações arenosas. As dunas formam os chamados "Lençóis".

No que se refere à vegetação, na maior parte do Parque ela inexiste. Os manguezais representam uma área muito pequena ligada aos solos de várzeas, acompanhando principalmente o curso e braços de rios. "Nas restingas, ocorrem espécies importantes na fixação de dunas". A fauna é muito rica, na parte litorânea do Parque, aves migratórias como maçaricos (Calidris fuscillis), trinca-reis-boreal (Sterna hirundo) e a marreca-de-asa-azul (Anas discors). Nos manguezais destacam-se a jacaretingá (Caiman c. crocodilus), o veado mateiro (Mazma americana) e a paca (Agout paca).

Ao analisar o ecossistema PNLM, verifica-se o quanto é frágil e o quanto é importante planejar as atividades turísticas para o local de acordo com os princípios da sustentabilidade.

Sabe-se o quanto cresce no Brasil e no mundo o interesse pelo ecoturismo e como esse assunto vem sendo discutido desde os anos 80 . Embora haja boa vontade por parte do governo federal e o surgimento de instituições privadas tratando do tema "turismo sustentável”, "ecoturismo", a prática ainda está muito distante do discurso. O ecoturisno 
no Brasil é impulsionado, quase que exclusivamente, pela oportunidade mercadológica, não gerando os benefícios sócio-econômicos e ambientais esperados.

Para que o turismo nos Lençóis Maranhenses seja um benefício para a economia local, para o meio ambiente e para as gerações futuras é necessário que seja desencadeado um programa de Educação Ambiental extensivo a todos os atores envolvidos no processo.

\subsection{0 - Educação Ambiental}

Cresce no mundo inteiro o interesse por um turismo onde o grande atrativo é a natureza, aumentando cada vez mais a relação do homem com o meio ambiente. As áreas com grande potencial ecoturístico no Brasil já foram mapeadas pela Embratur e divididas em Pólos de Desenvolvimento Ecoturístico, dentre eles os Lençóis Maranhenses.

Embora ainda não haja uma definição globalmente aceita para o ecoturismo, e o conseqüente enquadramento das atividades que devem ser consideradas nesse segmento, segundo estimativas da Embratur, o mercado ecoturístico está em franca expansão, sendo estimado o seu crescimento em cerca de $20 \%$ ao ano, conforme resultados obtidos em entrevistas realizadas junto a operadores turísticos especializados e peritos, e na observação do crescimento de agências operadoras de ecoturismo ${ }^{1}$.

No entanto, a oferta de destinos ecoturísticos depende da existência de áreas de elevado valor ecológico "caso dos Lençóis maranhenses", da maneira como essas áreas são geridas, da existência de infra-estruturas adequadas e da disponibilidade de recursos humanos qualificados.

Nesse contexto, a Educação Ambiental é fator preponderante para o sucesso das atividades ecoturísticos, pois, trata-se de uma atividade econômica dinâmica que requer ações "interinstitucionais articuladas", com a efetiva participação de todos os atores envolvidos.

1. Diretrizes para uma política nacional de ecoturismo, Embratur, 1994. 
È preciso aproveitar melhor o expressivo potencial natural e cultural existente no Brasil, como gerador de recursos adicionais para a conservação e proteção do meio ambiente e por outro lado, como fonte alternativa de desenvolvimento econômico e social, para as populações nativas.

Antes é preciso refletir sobre tudo que o homem tem feito ao planeta terra, pois ao longo dos séculos, a terra vem sofrendo constantes transformações ambientais causadas por agentes naturais. Entretanto, o homem é o único dos seres vivos que participa do ambiente natural e é capaz de atuar e intervir nele. A terra sempre forneceu ao homem os recursos naturais necessários à sua sobrevivência, tais como: água, madeira, frutas e tantos outros alimentos extraídos da mãe natureza.

O homem primitivo agredia a natureza de forma inconsciente, quando queimava as matas para plantar, atingindo mortalmente a fauna e a flora, sem nenhum sentimento de culpa, pois, na sua visão, tudo aquilo foi feito por Deus para o seu usufruto. Porém, o abuso propriamente dito contra a natureza, teve início com a revolução industrial no século XVII, agravando-se nos séculos XIX e XX com o crescimento da população.

O homem continuou agredindo a natureza progressivamente, especialmente nos países desenvolvidos. Poluindo as águas, destruindo as florestas e somente após alertas de estudiosos, no final da década de 60, a humanidade começou a tomar consciência do que estava fazendo com o meio ambiente e consigo mesmo, surgindo então a pergunta: caso o homem não aprenda a viver em harmonia com os elementos naturais, quais são as perspectivas de vida?

Consciente do quadro de ameaça à sua própria existência, os homens reuniram pela primeira vez em 1972, em Estocolmo, na Suécia, para tratar sobre o meio ambiente, encontro que recebeu o nome de ECO-72, promovido pela Organização das Nações Unidas, (ONU). Iniciava-se então uma grande discussão e o esforço mundial em defesa do meio ambiente. ${ }^{1}$

\footnotetext{
${ }^{1}$ Turismo, Espaço e Tempo, Ed. Senac, São Paulo, 2000.
} 
Embora tenha havido um certo avanço e o mundo inteiro tenha demonstrado interesse na preservação ambiental, a questão só voltou a ser debatida pela cúpula mundial em 1992, desta vez no Rio de Janeiro, - foi a Rio-92. Mais uma vez a ONU promovia um encontro para tratar das questões ambientais. Para estudiosos do assunto, quando 110 chefes de Estado e de Governo se reuniram naquela ocasião, dava-se um passo histórico de mobilização da humanidade para uma causa até então ignorada, "os povos da terra representavam-se, em seu conjunto, para acertar procedimentos que garantissem condições estáveis para o prosseguimento infinito da vida no planeta".

\begin{abstract}
Foi um avanço capital a aceitação do conceito de que a Terra é um lar para o conjunto da humanidade e que, como numa casa de família comum, todos devem colaborar para que tudo funcione adequadamente. O alerta Ambiental, propiciado pelos conhecimentos decorrentes do uso de técnicas novas em variados ramos das ciências, apontava para a construção de um degrau a mais na escada da evolução humana: o compartilhamento respeitoso.
\end{abstract}

(Revista Educação Ambiental, Senac, ano 11, nº 3, setembro/dezembro, 2002)

Passados dez anos, a cúpula mundial representada por 190 países, volta a se reunir em Joanesburgo - África do Sul, para avaliar o que se poderia chamar de Era Ambiental e traçar novos rumos para o planeta. Para diversos analistas que participaram do evento, o encontro foi uma total decepção. Ficou explícito no encontro que a Cúpula Mundial sobre Desenvolvimento Sustentável, em Joanesburgo, emitiu sinais contrários aos da Conferência Mundial sobre Meio Ambiente e Desenvolvimento Sustentável na Rio-92.

Para quem esperava um avanço, ficou a certeza que a humanidade perdeu em Joanesburgo, onde só houve um vencedor: "o mundo dos negócios - as grandes corporações".

Da avaliação da "Era Ambiental" também ficou uma triste constatação: de 1992 a 2002 o mundo registrou índices negativos em vários campos, especialmente, o aumento da pobreza, a concentração de riqueza ainda maior no pequeno número de países já excessivamente ricos e o pior, - o aumento considerável da degradação ambiental.

Fica uma frustração, mas a certeza de que é preciso lutar por um mundo melhor, por um turismo sustentável e por uma verdadeira Educação Ambiental. 
Conforme Enrique Leff ${ }^{2}$, o discurso do desenvolvimento sustentável não é homogêneo: vem marcado e diferenciado pelos interesses ambientais de diversos setores e atores sociais. Assim o processo educacional transmitirá e difundirá os princípios e valores das diferentes visões e propostas para alcançar a sustentabilidade.

A educação formal "popular" gerou uma percepção crítica do processo educativo, propondo uma intervenção participativa no desenvolvimento de conhecimentos e sua aplicação em estratégias de desenvolvimento endógeno para a melhoria das condições de vida de cada população.

A Educação Ambiental popular inscreve-se assim nesta tradição da educação crítica do modelo de desenvolvimento dominante, orientando a construção de uma nova racionalidade social. Nesse sentido, o conceito de formação ambiental é pertinente para compreender a transformação da realidade causada pela problemática ambiental do desenvolvimento. (Leff, Saber Ambiental, p.253).

Segundo a Constituição Brasileira, no seu Capítulo VI (Do Meio Ambiente), é dever do Estado promover a Educação Ambiental em todos os níveis de ensino e a conscientização pública para a preservação do meio ambiente.

A Educação Ambiental numa destinação turística como os Lençóis Maranhenses, onde se pratica o turismo ecológico, ou turismo de natureza, um recurso turístico que não pode ser ampliado e preciso ser rigorosamente preservado, tem que ter um programa com abrangência total e absoluta. Passando do morador mais novo ao pioneiro, do comerciante - quer seja aquele que vende o artesanato, o dono da pousada, do hotel ou restaurante, ao +estudante, o professor, motoristas de táxi, as empresas de turismo, todas as instituições públicas e privadas, assim como parceiros importantes como Senac e Sebrae. Todos podem dar uma importante contribuição tanto no que se refere a qualificação profissional como na Educação Ambiental.

\footnotetext{
${ }^{2}$ Autor de Saber Ambiental, Ed. Vozes, Petrópoles, 2002.
} 


\section{Capítulo 3 - Turismo nos Lençóis Maranhenses e seus atores.}

Neste capítulo serão apresentados os resultados da pesquisa realizada em Barreirinhas, por meio de entrevistas e questionários, com os atores envolvidos no processo turístico nos Lençóis Maranhenses.

Como o turismo é uma atividade econômica que tem no território, no patrimônio cultural e especialmente no patrimônio natural e na paisagem, suas principais matériasprimas - como é o caso dos Lençóis Maranhenses, é de fundamental importância o papel exercido pelo poder público, sem o qual não é possível produzir turismo. Por esse motivo a primeira entrevista foi direcionada ao poder público em Barreirinhas, envolvendo os seguintes órgãos: Prefeitura Municipal, Secretaria de Educação, Secretaria de Turismo, Cultura e Meio Ambiente e o IBAMA.

\section{1 - Entrevistas com Autoridades de Barreirinhas}

\section{Pergunta: - Quais as políticas do município de Barreirinhas para o desenvolvimento do turismo nos Lençóis Maranhenses?}

- Respostas:

1 - Prefeitura Municipal: - A Prefeitura está dotando a cidade de Barreirinhas de toda a infra-estrutura necessária para o desenvolvimento do turismo. Duas grandes obras estão em andamento visando o bem-estar da população e de todos os turistas que aqui chegam para conhecer as nossas famosas dunas e lagoas, além do nosso artesanato, nossa cultura, participar das nossas festas, que são muitas e acontecem durante todo o ano, tendo como destaque o carnaval e a vaquejada.

Depois da estrada que liga São Luís a Barreirinhas ter sido asfaltada, nesses últimos anos, em função do desenvolvimento do turismo, - o que aumentou consideravelmente a população da cidade, a primeira grande obra que está sendo executada é a rede de esgoto da cidade. A outra obra que também, a exemplo da estrada, dará um novo impulso ao turismo nos Lençóis, é a ampliação do aeroporto da cidade, que, no momento, só permite o pouso de aviões de pequeno porte. Com a ampliação do 
aeroporto a cidade poderá receber turistas diretamente de todas as regiões do Brasil e do exterior.

Com o crescimento do turismo nos últimos três anos, houve um aumento repentino da população de Barreirinhas, surgindo basicamente uma nova cidade - Nova Barreirinhas, onde além de construção de casas é preciso ampliar todos os serviços de saneamento básico, como água, luz, saúde, educação, segurança e geração de emprego para toda essa gente que chega, motivada pelas atividades turísticas, quer seja no mercado formal, em hotéis, pousadas, restaurantes, comércio em geral, que vem crescendo muito na cidade ou no mercado informal, no artesanato, na pesca, na lavoura.

A prefeitura está trabalhando dia e noite para que se tenha uma cidade limpa, ordeira, com uma infra-estrutura que possibilite receber bem o turista. Contamos com vários órgãos públicos envolvidos na melhoria dessa destinação turística que já está recebendo pessoas de todos os estados brasileiros e de vários países do mundo, gerando cada vez mais emprego, renda, impostos e melhores condições de vida para a população.

2- Secretaria de Educação: - as escolas estão contribuindo com o desenvolvimento do turismo preparando seus alunos para serem multiplicadores na preservação ambiental. A Secretaria de Educação conta com um programa de Educação Ambiental, numa importante parceria com o IBAMA, não somente na preparação de seus alunos, mas também da população em geral, desenvolvendo palestras, cursos, eventos voltados para a preservação do meio ambiente, como jogos e gincanas. As escolas contam ainda com a colaboração de estudantes de São Luís que, periodicamente, desenvolve ciclos de palestras sobre Educação Ambiental. A melhor forma da Secretaria de Educação contribuir com o desenvolvimento do turismo local é por meio de ações educativas objetivando a preservação do meio ambiente.

3 - Secretaria de Turismo, Cultura e Meio Ambiente: - o trabalho desenvolvido pela Secretaria de Turismo e Meio Ambiente nos Lençóis Maranhenses conta com três importantes parceiros: Sebrae - que é responsável pela qualificação profissional de todo o pessoal do artesanato, orientando não só "como fazer", mas como vender, montar e administrar um pequeno negócio. È importante salientar que Barreirinhas é o principal centro artesanal do Maranhão, graças à disponibilidade de matérias-primas na região.

O Senac é outro importante parceiro da Secretaria de Turismo, Cultura e Meio Ambiente de Barreirinhas. O Departamento Regional do Senac do Maranhão enviou para a 
cidade uma unidade móvel de informática e administração para qualificar profissionais nessas áreas, como também em Turismo e Hospitalidade. São desenvolvidos diversos cursos com ênfase para Garçom e Aperfeiçoamento para Atendente de Turismo.

O IBAMA é outro parceiro indispensável da Secretaria de Turismo, Cultura e Meio Ambiente e um dos órgãos mais importantes para o turismo nos Lençóis Maranhenses. Além de desenvolver importante papel em defesa do meio ambiente da região, gerencia, regula, de acordo com as leis ambientais, a visitação do PNLM, especialmente nos períodos de grandes festas em Barreirinhas, como a Vaquejada, quando se verifica um turismo de massa, fiscaliza e emite multas, quando necessário, para aqueles que desobedecem e degradam o meio ambiente.

São vários os problemas enfrentados pelo IBAMA na região dos Lençóis Maranhenses ${ }^{1}$, sendo os mais graves: os desmatamentos, as queimadas e as construções irregulares nas margens do rio Preguiças.

Com a explosão do turismo nos Lençóis Maranhenses, cresce a especulação imobiliária, e a exemplo de outras destinações turísticas, os nativos não resistem a pressão de empresários vindos de diversas partes do estado e do país, que compram suas pequenas propriedades e incorporam a essas propriedades áreas que são do município, para construir seus empreendimentos, necessitando da enérgica intervenção dos fiscais do IBAMA.

Todos as programações desenvolvidas pela Secretaria de Turismo, em parceria com Senac, Sebrae ou IBAMA, têm como tema central o desenvolvimento do turismo de forma sustentável. A Educação Ambiental é prioridade em todas as ações educativas promovidas pelo município, visando criar uma consciência ambiental em todos os moradores da região dos Lençóis Maranhenses, para servir de exemplo para os turistas que aqui chegam, muitas vezes sem o compromisso de preservar as nossas riquezas que são: o rio Preguiças, as dunas, as lagoas e a cultura do lugar.

\footnotetext{
${ }^{1}$ O IBAMA também encontra resistência para impor suas leis junto aos nativos, pescadores e lavradores não concordam com certas proibições impostas em nome da preservação do Meio Ambiente.
} 
O morador local é um dos mais importantes atores numa destinação turística, especialmente os pioneiros, - pessoas que quando fixaram suas residências no local desconheciam o significado da palavra turismo e de repetente se vêem incomodados e muitas vezes até expulsas do seu lugar quando o mesmo é transformado numa destinação turística. Os mais jovens reagem de outra maneira, e encontram no turismo uma oportunidade de ver o seu lugar sair do anonimato e ter uma melhoraria de vida, com a possibilidade de arranjar um emprego gerado pelas atividades turísticas.

\section{2 - Entrevista com Moradores, donos de Pousadas e Agências de Turismo}

\section{Qual a importância do turismo para a cidade de Barreirinhas e para seus moradores?}

Respostas:

1. Pioneiro (79 anos): - "Eu gostava mais quando aqui não se falava nesse negócio de turismo. A cidade era mais calma, todo mundo era conhecido, não tinha briga nem furtos. Só era ruim porque não tinha estrada, adoecia uma pessoa aqui, até ela chegar em São Luís, muitas vezes morria na estrada.

A gente sempre teve as dunas e o rio Preguiças e as pessoas que vinham aqui antigamente, até gente do estrangeiro, não eram chamadas de turistas, hoje é que qualquer estranho que aparece na cidade chamam de turista. Tem muita gente ganhando dinheiro com o turismo. Muitas moradas foram transformadas em pousadas, mais para trás se chamava era pensão, hoje é pousada. Eu mesmo nunca ganhei nada com o turismo, mas a cidade cresceu, o movimento agora é o ano todo. É gente chegando, gente saindo, ônibus e carros pequenos entrando na cidade, vindos de todo lugar. Então, pra muita gente o turismo tá sendo bom."

2. Estudante (16 anos): - "O turismo aqui pode ser visto de duas maneiras, tanto pelo lado bom, como também pelo lado ruim. O lado bom é porque, como você ver, a cidade tá melhorando. Isso aqui antes era só areia, hoje estão trabalhando para deixar a cidade mais bonita, estão fazendo o calçamento, a rede de esgoto, tudo isso porque as autoridades ficam com vergonha dos turistas chegarem aqui e encontrarem tudo sujo, as ruas esburacadas, assim, é esse o lado bom do turismo. O lado ruim, ninguém daqui 
gosta, é quando chega muitos turistas de uma vez, muitos deles mal educados, sujam tudo, bagunça, acham porque estão pagando não precisa respeitar a cidade, consideram que as pessoas daqui são bestas e ficam tirando onda. Mas também não são todos, tem muita gente educada também, que até orientam os daqui, como não poluir o rio e cuidar bem do meio ambiente. Por isso é que eu acho que o turismo tem as duas coisas, a boa e a ruim.".

3. Taxista: - "A cidade agora é outra, meu amigo. Depois que asfaltaram essa estrada que vai para São Luís, nossa vida mudou. O turismo é um negócio bom pra todo mundo. Conheço gente aqui que não tinha nada, era pobre demais. Hoje tem casa boa, tem carro só as custas dos turistas. Todo dia aqui chega gente de fora, muitos turistas estrangeiros, só gente boa, paga bem, tem muita educação, não reclama de nada. Eles querem mesmo é ver as dunas, as lagoas, tiram foto de tudo, até dos passarinhos e dos artesanatos que o pessoal daqui faz. São chegados nas mocinhas daqui, que são muito espertas. É comum a gente ver um galegão enorme, da Inglaterra, da Holanda, da Alemanha ou dos Estados Unidos, brancos de alhos azuis, agarrados com essas mocinhas daqui de Barreirinhas. Na verdade todo mundo se dá bem, aqui não seria diferente, se no Brasil todo é assim, onde tem turista rola dinheiro e rola tudo. Eu só quero acrescentar que Barreirinhas vai ser em breve a melhor cidade do Maranhão e tudo por causa do turismo".

4. Garçom: - "Essa cidade aqui poderia ser como qualquer outra cidadezinha atrasada do Maranhão se não fosse o turismo. Aqui até para quem não tem uma profissão é um lugar bom pra se ganhar dinheiro, porque aqui tem pouca gente com profissão, agora que tá no começo, todo mundo acaba aprendendo na marra, na prática, porque agora que o Senac começou dar alguns cursos junto com o pessoal da Secretaria de Turismo, mas a gente aprende com os donos das pousadas, dos restaurantes, e de repente já é um profissional. Eu vou para São Luís fazer um curso de cozinheiro e vou voltar para Barreirinhas, porque o turismo aqui só vai melhorar, o número de pousadas vai aumentar, já estão construindo hotéis, com certeza o mercado de trabalho aqui vai oferecer muitas vagas nos próximos anos.

\section{Donos de Pousadas}

Os donos de pousadas são atores importantes no desenvolvimento do turismo nos Lençóis Maranhenses. As entrevistas realizadas com esses atores visaram colher suas 
opiniões sobre o perfil do turista dos Lençóis, a sua procedência, quanto tempo fica na cidade e qual é o tipo de turismo, na sua visão, que provoca impactos negativos do ponto de vista ambiental e não interessa muito aos Lençóis maranhenses.

6. Dono de pousada em Caburé: - "O turista que vem conhecer os Lençóis é geralmente uma pessoa de bom poder aquisitivo, ele fica aqui de dois a cinco dias em média. Se ele quer conhecer só o Parque dos Lençóis em dois dias já viu tudo, nesses casos, são turistas que estão passando férias em São Luís e tiram uns dias para conhecer os Lençóis. Hoje é raro o turista que vem para o Maranhão, quer seja para São Luís ou outra cidade, que não sinta o desejo de conhecer os Lençóis. Mas tem os casos também de turistas estrangeiros que chegam a passar até duas semanas aqui, são pessoas que ficam aqui fazendo pesquisas e conhecem o Parque, a Ilha dos Lençóis em Cururupu, a Floresta dos Guarás e vão até o delta do Parnaíba, às vezes chegando até Jericoacoara no Ceará. Tem também os turistas que são de São Luís e de cidades vizinhas que passam o dia aqui e no final da tarde voltam para suas cidades, consomem algumas cervejas, almoçam, fazem uma bagunça danada, principalmente quando são muitos. É o tipo de turista que a gente não gosta, primeiro porque quando é muita gente o nosso atendimento fica prejudicado. Aqui a gostamos de atender bem o turista, porque quando ele volta não deixa de vir aqui e sempre passa a informação para outros turistas.

O turismo de massa ${ }^{2}$ não é uma boa para os Lençóis, aqui temos muita preocupação com o meio ambiente e esse tipo de turismo é o que mais degrada as nossas paisagens e ainda tem o problema do lixo, quanto mais gente junta, maior a produção de lixo. $\mathrm{O}$ turista quando está em grupo muito grande, parece que perde um pouco da sua educação e sempre tem uns que querem aparecer para o grupo.A nossa preocupação com o meio ambiente tem que ser um exemplo para o turista que vem aqui.O turista vendo tudo limpo com certeza segue o exemplo, se ele sente que nós mesmos que somos da terra não cuidamos do que é nosso, imagine ele que não sabe nem se ainda vai voltar aqui e não tem nenhum compromisso com o lugar! Já estamos providenciando uma sinalização, de Barreirinhas até aqui em Caburé, uma espécie de campanha educativa, - serão várias placas dizendo: "preserve a natureza".

\footnotetext{
${ }^{2}$ Turismo de massa - o maior responsável pela degradação do meio ambiente.
} 
7. Dono de Pousada em Barreirinhas: - "O turismo nos Lençóis Maranhenses recebeu grande impulso com a construção da estrada, isso não se pode negar, mas quando a estrada era ruim e muita gente não tinha coragem de passar 8 horas dentro de um ônibus na poeira ou na lama, o turista que vinha para os Lençóis era o tipo de turista que dava gosto receber. Era gente de ótimo poder aquisitivo, passava uma semana aqui, se interessava não só pela natureza, mas queria saber tudo sobre o lugar, sobre o modo de vida da cidade. Com esse tipo de turista a gente ganhava muito mais, quer dizer, era um turismo seletivo e sem preocupação com esse negócio de degradação ambiental.

Hoje tem muito farofeiro, essa turma que vem de ônibus fretado, tipo excursão, não dar lucro para ninguém. Esse sim é o predador, chega aqui trazendo até o lanche na sacola, não gasta quase nada na cidade, faz arruaça, tira o sossego da gente, isso na verdade a gente não pode nem chamar de turista.

Porém, não podemos negar que o turismo virou mania nacional, apesar do farofeiro, a nossa cidade recebe um número muito bom de turistas de outros países, do Maranhão mesmo vem muita gente que tem grana. Muitos chegam com a intenção de sondar as possibilidades de montar um negócio, depois se apaixonam pelas dunas e pelo povo desse lugar. Essa é uma cidade muito boa de se morar. Aqui ainda se tem um estilo de vida bem antigo, a cidade é pequena, como você ver, as pessoas aqui ainda guardam a tradição de no final da tarde colocar a cadeira na calçada e ficar conversando".

8. Promotor de eventos em Barreirinhas: - "Aqui nos Lençóis não podemos ficar aguardando o turista, aquele que vem só em função das nossas belezas naturais na alta temporada, assim a cidade ficaria vazia no restante do ano, o que seria péssimo para os donos de pousadas, hotéis e restaurantes, que vivem do turismo.

É preciso inventar, ser criativo, tornar a cidade uma atração permanente. Já temos o lugar mais bonito do Brasil, em nenhum outro canto do país se ver as belezas naturais que temos aqui nos Lençóis, o negócio é fazer com que as pessoas da região e turistas que venham aqui na baixa temporada, tenham Barreirinhas como ponto de referência, um lugar onde a beleza se mistura com o lazer e a qualidade de vida. Viver é desfrutar as 
belas coisas que a vida nos oferece, a paisagem, as relações pessoais, o trabalho e a "festa".

Promovemos uma média de duas festas por mês. Saímos da alta temporada, quando o fluxo de turistas aqui é muito grande, entramos no carnaval que é um dos melhores do Maranhão, onde a grande atração é o "Baile do Avaí". Outra festa que mexe com a cidade é a "A noite das Personalidades", onde entrega-se o troféu "Lençóis de Areia". As gincanas são eventos culturais da maior importância para a cidade, envolvendo, geralmente, temas ligados à preservação do meio ambiente, - são verdadeiras campanhas em defesa da natureza, visando a educação ambiental. Para agitar mais a cidade e promover o turismo, são freqüentes também os shows com artistas de São Luís, de estilos variados, - reggae, forró e MPB.

A cidade de Barreirinhas tem uma agenda cultural invejável: depois dos meses agitados de janeiro e fevereiro, março é o mês em que se comemora o aniversário da cidade; em abril tem festa comemorativa pelo dia do índio; maio é dedicado ao trabalhador e às mães; em junho a cidade festeja a criação do Parque Nacional dos Lençóis Maranhenses e promove inúmeros eventos dedicados ao meio ambiente, além das tradicionais festas juninas e do pescador; em agosto além da festa de São Bernardo e festa do dia dos pais, comemora-se a famosa festa da banana; em setembro a Festa da Independência e Defesa da Fauna; em outubro tem a semana da criança, dia do educador ambiental e a Festa do $\mathrm{Caju}^{3}$; em novembro comemora-se a Proclamação da República e o dia da cultura; em dezembro, além das festas natalinas, tem a festa de Nossa Senhora da Conceição e a "festa da castanha".

As festas do calendário cultural de Barreirinhas somadas a tantas outras que promovemos durante o ano, torna a nossa cidade um lugar capaz de atrair turistas em todos os meses do ano. Aqui não exploramos ninguém, o turista é bem atendido, faz amizades com os nativos e sempre voltam ou indicam o lugar para seus amigos passarem pelo menos uns dias de suas férias".

A cidade possui hoje uma estrutura muito boa no que se refere à hospedagem. Existem pousadas para todos os gostos. Só no centro da cidade, temos dezenas de pousadas. Também em Caburé e Atins existem ótimas pousadas. Recentemente foi 
inaugurado um resort nas margens do rio Preguiças próximo a Barreirinhas, para quem tem um poder aquisitivo melhor. Temos restaurantes espalhados pela cidade, na beira rio o turista pode encontrar uma comida variada e pratos regionais. A nossa culinária é uma maravilha. Portanto, o nosso negócio é festa, - venha festejar conosco e nunca mais você vai esquecer os Lençóis Maranhenses”.

É difícil traçar um perfil do turista dos Lençóis, pois aqui vem gente de muitos estados do Brasil, do exterior, sem contar com o maranhense, que já se apaixonou de vez pelos Lençóis. Hoje no Maranhão dizer que não conhece os Lençóis Maranhenses é sinal de atraso. Como meu caso é festa, quanto mais gente melhor, mas todos sabem que os eventos que promovemos aqui trazem uma marca "Educação Ambiental".

O povo de Barreirinhas já começa a internalizar esse sentimento de preservar as nossas belezas naturais para as gerações futuras. Devemos tudo isso a pesquisadores como você, que dão uma grande contribuição à nossa cidade, desenvolvendo seus trabalhos de pesquisa sempre dando orientação aos nativos sobre preservação do meio ambiente. Aqui todo mundo já ouviu muitas vezes esse termo - Turismo Sustentável”.

9. Dono de Agência de Turismo em Barreirinhas: - “Temos uma grande responsabilidade com o desenvolvimento das atividades turísticas nos Lençóis Maranhenses. Em primeiro lugar porque os passeios, tanto pelo rio Preguiças como por terra, se constituem na grande razão da vinda do turista aos Lençóis. É nesse ponto que cresce a nossa responsabilidade, porque precisamos proporcionar ao turista momentos que justifiquem o seu investimento, vindo, muitas vezes, de muito longe, com imagens produzidas pela mídia que o motivaram a conhecer o lugar, pacotes turísticos relativamente caros, sendo mais do que necessário um tratamento de primeira qualidade, para que a sua expectativa seja correspondida. Para tanto, nossos funcionários precisam de uma ótima qualificação profissional. Os nossos condutores de barco ou toyota, assim como os nossos guias devem estar preparados para responder todas as dúvidas e curiosidades dos turistas, como contar a história do Preguiças, suas lendas, como também identificar todas as lagoas.

\footnotetext{
${ }^{3} \mathrm{O}$ caju é uma das riquezas do lugar, aproveita-se a castanha como produto de exportação, o fruto alimenta os nativos e também serve como ração para o gado.
} 
O sucesso da nossa atividade depende muito da qualidade dos nossos serviços, isso quer dizer que o nosso funcionário que dirige uma toyota, assim como o guia que conduz os turistas pelas dunas e lagoas, e o outro que pilota uma lancha, precisa ser um profissional polivalente, ou seja, está qualificado para atender o turista, não só na sua condução, mas também no que se refere à informação e orientação sobre a necessidade da preservação do meio ambiente. Aqui o turista precisa saber que a natureza é o nosso maior bem, a preservação ambiental é o nosso lema.

Felizmente, a maioria dos turistas que aqui chegam, principalmente por meio de pacotes turísticos, envolvendo além dos Lençóis outras destinações, como São Luís e Delta do Parnaíba, tem uma certa consciência ambiental, são, na maioria, defensores do meio ambiente, especialmente os estrangeiros. Com relação ao tipo de turismo nocivo aos Lençóis Maranhenses, aqui em Barreirinhas, tanto faz ser dono de uma Agência de Turismo ou de uma Pousada, ninguém gosta do turismo de massa. A gente tem observado que mesmo aqueles que não são da terra quando começam a trabalhar aqui se apaixonam pela cidade e incorporam a idéia de que devemos tratar bem o nosso patrimônio e não suportam a possibilidade de degradação ambiental”.

10 Dona de Restaurante em Barreirinhas: - o turismo aqui nos Lençóis está cada dia melhor. Antes o movimento do nosso restaurante oscilava muito, bom nos meses de janeiro e fevereiro, fraco no período de março a maio e ótimo nos meses de junho, julho e agosto, - é a melhor época para conhecer os Lençóis, as lagoas estão cheias, é o período do ano que mais ganhamos dinheiro. De setembro até final de outubro, o movimento fica fraco, em novembro e dezembro volta a ser muito bom. Aqui, vem todo tipo de turista, de todo lugar, se fosse pelo nosso gosto a cidade ficaria cheia o ano todo. Nesses últimos anos, melhorou muito, a cidade também melhorou, o transporte, as estradas estão asfaltadas, isso facilita a movimentação do turista.

Sobre o meio ambiente, todo mundo fala nisso aqui. A preocupação maior é com o rio Preguiças, tem muitas campanhas para não jogar lixo no rio, não dar banho nos jumentos no rio, tem até cartilhas circulando na cidade ensinando as pessoas sobre preservação ambiental, as lagoas e dunas são também a preocupação de todos. 
Com relação ao nosso cardápio, seguimos a mesma linha da culinária maranhense: galinha ao molho pardo é a nossa especialidade, peixada, arroz-de-cuxá, Maria Isabel, camarão e baião de dois (arroz misturado com feijão). Os preços são camaradas, atendem desde o turista estrangeiro ao maranhense, ninguém reclama".

\section{3 - Entrevista com o Turista}

Considerado o principal ator no processo turístico, o turista nesta pesquisa também recebeu tratamento diferenciado, ou seja, para conhecer melhor o seu perfil foi elaborado um questionário contendo 12 perguntas, cujas respostas serão apresentadas a seguir, em forma de tabelas.

1. Qual a sua residência permanente?

\begin{tabular}{|c|c|c|}
\hline LOCAL & NÚMERO & PORCENTAGEM \\
\hline Exterior & 06 & $15 \%$ \\
\hline Maranhão & 15 & $37,5 \%$ \\
\hline Outros estados do Brasil & 19 & $47,5 \%$ \\
\hline TOTAL & 40 & $100 \%$ \\
\hline
\end{tabular}

Respostas - TABELA 1

2. O que o induziu a fazer esta viagem aos Lençóis Maranhenses?

\begin{tabular}{|c|c|c|}
\hline MOTIVO & NÚMERO & PORCENTAGEM \\
\hline Atrativos naturais & 40 & $100 \%$ \\
\hline $\begin{array}{c}\text { Manifestações populares } \\
\text { (folclore, artesanato, festas } \\
\text { regionais) }\end{array}$ & 00 & 00 \\
\hline TOTAL & 40 & $100 \%$ \\
\hline
\end{tabular}

Respostas - TABELA 2 
3. Qual a sua permanência nos Lençóis Maranhenses?

\begin{tabular}{|c|c|c|}
\hline PERMANÊNCIA & NÚMERO & PORCENTAGEM \\
\hline Até Dois Dias & 28 & $70 \%$ \\
\hline De dois a cinco dias & 10 & $25 \%$ \\
\hline Mais de 5 dias & 02 & $5 \%$ \\
\hline TOTAL & 40 & $100 \%$ \\
\hline
\end{tabular}

Respostas - TABELA 3

4. Que tipo de transporte você utilizou para chegar aos Lençóis Maranhenses?

\begin{tabular}{|c|c|c|}
\hline TIPO DE TRANSPORTE & NÚMERO & PORCENTAGEM \\
\hline Automóvel & 27 & $67,5 \%$ \\
\hline Ônibus & 11 & $27,5 \%$ \\
\hline Avião & 02 & $5 \%$ \\
\hline TOTAL & 40 & $100 \%$ \\
\hline
\end{tabular}

Respostas - TABELA 4

5. Antes de chegar aos Lençóis, qual era a sua expectativa quanto à oferta turística do lugar?

\begin{tabular}{|c|c|c|}
\hline EXPECTATIVA & NÚMERO & PORCENTAGEM \\
\hline Excelente & 35 & $87,5 \%$ \\
\hline Boa & 05 & $12,5 \%$ \\
\hline Regular & 00 & 00 \\
\hline Ruim & 00 & $100 \%$ \\
\hline TOTAL & 40 & 00 \\
\hline
\end{tabular}

Respostas - TABELA 5 
6. Depois de ter conhecido os Lençóis Maranhenses, como você qualifica o lugar?

\begin{tabular}{|c|c|c|}
\hline CONCEITO & NÚMERO & PORCENTAGEM \\
\hline Excelente & 37 & $92,5 \%$ \\
\hline Bom & 03 & $7,5 \%$ \\
\hline Regular & 00 & 00 \\
\hline Ruim & 00 & 00 \\
\hline TOTAL & 40 & $100 \%$ \\
\hline
\end{tabular}

Respostas - TABELA 6

7. Como você avalia os serviços turísticos nos Lençóis Maranhenses?

\begin{tabular}{|c|c|c|}
\hline $\begin{array}{c}\text { QUALIDADE DOS } \\
\text { SERVIÇOS }\end{array}$ & NÚMERO & PORCENTAGEM \\
\hline Excelente & 12 & $30 \%$ \\
\hline Boa & 21 & $52,5 \%$ \\
\hline Regular & 07 & $17,5 \%$ \\
\hline Ruim & 00 & 00 \\
\hline TOTAL & 40 & $100 \%$ \\
\hline
\end{tabular}

Respostas - TABELA 7

8. Que tipo de hospedagem utilizou nesta cidade?

\begin{tabular}{|c|c|c|}
\hline TIPO & NÚMERO & PORCENTAGEM \\
\hline Hotel & 06 & $15 \%$ \\
\hline Pousada & 25 & $62,5 \% \%$ \\
\hline Casa de Parentes/Amigos & 09 & $22,5 \%$ \\
\hline TOTAL & 40 & $100 \%$ \\
\hline
\end{tabular}

Respostas - TABELA 8 
9. Antes de chegar aos Lençóis Maranhenses, visitou outras destinações turísticas vizinhas?

\begin{tabular}{|c|c|c|}
\hline $\begin{array}{c}\text { DESTINAÇÃO } \\
\text { TURÍSTICA }\end{array}$ & NÚMERO & PORCENTAGEM \\
\hline São Luís & 32 & $80 \%$ \\
\hline Delta do Parnaíba & 06 & 00 \\
\hline Jericoacoara & 00 & $5 \%$ \\
\hline Só os Lençóis Maranhenses & 02 & $100 \%$ \\
\hline TOTAL & 40 & \\
\hline
\end{tabular}

Respostas - TABELA 9

10. Durante sua permanência nos Lençóis Maranhenses, recebeu alguma orientação sobre Preservação Ambiental?

\begin{tabular}{|c|c|c|}
\hline RESPOSTAS & NÚMERO & PORCENTAGEM \\
\hline Sim & 16 & $40 \%$ \\
\hline Não & 24 & $60 \%$ \\
\hline TOTAL & 40 & $100 \%$ \\
\hline
\end{tabular}

Respostas - TABELA 10

11. Na sua opinião de quem é a responsabilidade pela preservação ambiental em destinação turística tipo Lençóis Maranhenses?

\begin{tabular}{|c|c|c|}
\hline RESPOSTA & NÚMERO & PORCENTAGEM \\
\hline $\begin{array}{c}\text { Secretaria de turismo e meio } \\
\text { ambiente }\end{array}$ & 18 & $45 \%$ \\
\hline IBAMA & 10 & $25 \%$ \\
\hline Prefeitura & 00 & $30 \%$ \\
\hline De todos & 12 & $100 \%$ \\
\hline TOTAL & 40 & 00 \\
\hline
\end{tabular}

Respostas - TABELA 11 
12. A preservação da cultura local é importante como atrativo turístico ?

\begin{tabular}{|c|c|c|}
\hline RESPOSTA & NÚMERO & PORCENTAGEM \\
\hline Sim & 40 & $100 \%$ \\
\hline Não & 00 & 00 \\
\hline Não sabe & 00 & $100 \%$ \\
\hline TOTAL & 40 & 00 \\
\hline
\end{tabular}

Respostas - TABELA 12

\section{4 - Análise das Entrevistas.}

3.4.1 - Autoridades de Barreirinhas: com o objetivo de conhecer as políticas do município para o desenvolvimento do turismo nos Lençóis Maranhenses, percebeu-se que todos os órgãos do município envolvidos com o turismo têm um compromisso com a preservação do meio ambiente.

A Prefeitura de Barreirinhas, ao mesmo tempo em que se preocupa com a infraestrutura da cidade, executando obras como a rede de esgotos, ampliação de aeroporto, preocupa-se também com o crescimento vertiginoso da cidade e de sua população, tendo que ampliar todos os serviços básicos como saúde, educação e segurança. A Secretaria de Turismo, Cultura e Meio Ambiente em conjunto com SENAC e SEBRAE, têm a função de promover o turismo sustentável, a qualificação profissional e a Educação Ambiental nos Lençóis Maranhenses. Ao IBAMA cabe a dupla função de fiscalizar e multar os infratores, e ainda contribuir com a Educação Ambiental na qualificação de profissionais para o exercício da função de agente ambiental, ficando tudo isso bem claro nas entrevistas.

Entretanto, somente a população local e os turistas são capazes de avaliar a contribuição de todos esses órgãos no desenvolvimento das atividades turísticas na região, especialmente no que se refere à questão da sustentabilidade. O desejo é que na prática tudo funcione e que cada um desses órgãos saiba a sua real importância na formação de uma consciência ambiental na importante missão de preservar esse tesouro 
natural "Lençóis Maranhenses" para as gerações futuras, sem esquecer que tanto o turista quanto os moradores do local também são responsáveis pela busca desse objetivo.

Quanto maior a visibilidade do processo de preservação de um local, mais fácil será atrair mais pessoas para esse lugar e o engajamento de todos nesse processo, mesmo do estrangeiro, pois a imagem é uma característica do produto turístico determinante no processo de decisão de compra do consumidor. Vale lembrar que a imagem que o consumidor tem de um lugar pode ser formulada, muitas vezes, a partir de informações de amigos, reportagens, onde merece destaque a educação da população local, a beleza do lugar e a determinação explícita de todos os atores de preservar o meio ambiente.

\subsection{2 - Moradores, donos de Pousadas e Agências de Turismo}

O segundo grupo entrevistado, composto por moradores do local, ao responder a pergunta sobre a importância do turismo para Barreirinhas e para a comunidade, demonstrou uma coerência ao responder sobre o tipo de turismo que traz uma certa preocupação a todos os segmentos da região dos Lençóis, apontando o "turismo de massa" como prejudicial para uma destinação turística que tem um ecossistema frágil, totalmente sujeito à degradação ambiental.

Embora todos vejam o turismo como o grande fator de desenvolvimento da cidade, a "alma do lugar" ainda fala mais forte. O sentimento de preservar os recursos naturais está para a comunidade dos Lençóis Maranhenses como prioridade máxima. Até mesmo um taxista ou dono de restaurante que sonham em ter uma cidade cheia de gente o tempo todo, para o sucesso de seus negócios, não esquecem que se os turistas e a própria comunidade poluírem o rio Preguiças, se não seguirem as normas do IBAMA nas visitas às dunas e lagoas, onde não se permite a construção de hotéis nem restaurantes, como também jogar lixo no local, haverá um declínio nessa destinação turística que é a mais importante do Maranhão.

Outro fato que merece destaque é a preocupação de um organizador de eventos do local de promover eventos voltados para a Educação Ambiental, especialmente as gincanas, que transformam cada estudante num multiplicador da nobre arte de preservar 
o meio ambiente. Isso faz crescer o amor de toda a população pelos símbolos da cidade que são: as dunas o rio Preguiças e as lagoas.

O pioneiro chega a ter saudade da antiga estrada sem asfalto, onde pouca gente se arriscava a enfrentar nove horas de viagem. O turismo já existia, mas em pequena escala. A rejeição pelo turismo de massa retrata o desejo dos antigos moradores do lugar de ter um meio ambiente saudável, sem risco de degradação. Esse mesmo sentimento é compartilhado por donos de pousadas em Caburé e Barreirinhas.

Algumas dessas pessoas mesmo tendo nascido em outros lugares, hoje se consideram do lugar e não suportam a idéia de invasão de grandes grupos que já começam a mudar o cenário na outrora pequena e pacata cidade de Barreirinhas, que já conta com dois grandes empreendimentos imobiliários: "O Porto Preguiças Resort, moderno, com apartamentos luxuosos e tendo ao centro uma piscina de 700 metros quadrados e do lado oposto, nas margens do rio Preguiças, o Parque dos Lençóis Eco Resort, um projeto que prevê a construção de cem chalés, sendo que oitenta já estão construídos, ocupando uma área de sessenta mil metros quadrados". (Revista Época, 20 de outubro de 2003).

Isso é apenas uma amostra do que será a região dos Lençóis Maranhenses nos próximos cinco anos. A preocupação de donos de pequenas pousadas procede por tudo que se tem visto em destinações turísticas emergentes. Os grandes grupos vão chegando e ocupando seus lugares e ao mesmo tempo expulsando os antigos comerciantes, os nativos. A pressão imobiliária é inevitável, onde o poder econômico fala sempre mais alto. O turismo de massa também é impossível ser contido. Entretanto, a população local precisa está armada para combater o inimigo, sua arma não pode ser outra senão a Educação Ambiental.

A mídia poderá exercer um importante papel na construção de uma consciência ambiental coletiva. As campanhas em defesa do meio ambiente terão que ser a marca do lugar, de tal forma que Lençóis Maranhenses represente no imaginário de todos - Dunas, Lagoas e Educação Ambiental. 
É preciso alertar as autoridades maranhenses para que não deixem acontecer a essa região, que está virando moda no Estado e despertando o interesse de empresários do ramo de Turismo e Hospitalidade de várias partes do Brasil, o mesmo destino de outras áreas do Maranhão que, segundo dados do IBAMA, "vêm sofrendo nas últimas décadas, uma crescente degradação ambiental caracterizada pela ocupação desordenada do espaço geográfico e por políticas econômicas que depreciam a qualidade dos ecossistemas".

Em $328.663 \mathrm{~km}^{2}$ de área, o Maranhão apresenta entre os ecossistemas mais representativos a floresta tropical úmida (tipo amazônica), o cerrado, os manguezais, as dunas, os estuários, as praias, as bacias lacustres, os campos inundáveis e os cocais, além dos recifes de coral, deltas e da caatinga maranhense (o carrasco). Em todos esses ambientes verifica-se a ação antrópica em diferentes graus. (Secretaria do Meio Ambiente e Turismo do Maranhão, 1991)

Embora não seja uma característica apenas do Maranhão esse descaso pela preservação do meio ambiente, o que não muda a situação, o caso dos Lençóis Maranhenses é muito mais preocupante do que se imagina, pois os estudos realizados pela Secretaria de Meio Ambiente do Estado em conjunto com o IBAMA sobre impacto ambiental, demonstram que as dunas do Estado do Maranhão podem sofrer como também provocar impactos no próprio meio ambiente. Um dos exemplos clássicos de ação natural das dunas é a invasão que estas promovem nos manguezais dos Lençóis Maranhenses, chegando a soterrar as raízes das árvores.

Em Vassouras as dunas já destruíram uma enorme área de manguezais, onde se nota uma grande quantidade de árvores mortas. É visível a ação das dunas naquela área e como as mesmas se movimentam empurrando o manguezal em direção ao rio Preguiças. Como se trata de uma ação da natureza, somente o tempo dirá como o manguezal vai resistir e por quantos anos aquela parte do rio ficará protegida. Trata-se de um fenômeno interessante e digno de estudos.

Enquanto se trata de fenômenos naturais o negócio é deixar por conta da mãe natureza, entretanto a ação antrópica nociva ao meio ambiente é preciso ser combatida. Se por um lado a natureza já contribui para a sua própria degradação, no caso da movimentação das dunas que destroem os manguezais e mudam as lagoas de lugar, invadem as residências dos nativos, outra preocupação que já está mexendo com a 
população é a questão da destruição dos buritizais, matéria prima de uma das principais atividades do local, - o artesanato.

Apesar de existir em todas as localidades da região, o buriti para o povo dos Lençóis Maranhenses tem o mesmo significado do babaçu para os nativos da região dos cocais, também no Maranhão. Tanto do babaçu como do buriti, tudo se aproveita. E por essa razão em muitas áreas do Estado essa riqueza típica do lugar começa a minguar. Por isso os nativos que vivem do artesanato em Barreirinhas, assim como os técnicos do SEBRAE que orientam e incentivam os artesãos na produção e comercialização dos produtos, e principalmente o IBAMA, todos juntos precisam encontrar uma saída para que num futuro não muito distante, o buriti não seja apenas uma lembrança de uma palmeira chamada de "árvore da vida" pelos nativos de Barreirinhas.

\subsection{3 - Turistas:}

Foram realizadas, por meio de questionários, quarenta entrevistas com turistas, no período de 28 a 31 de agosto de 2003 na região dos Lençóis Maranhenses. Os resultados estão nas 12 tabelas conforme a seguinte análise:

. Na tabela 1, respondendo a pergunta sobre residência fixa, 15\% dos turistas entrevistados residem no exterior, o que comprova que os Lençóis Maranhenses já entraram definitivamente no roteiro do turista internacional.O maranhense também tem demonstrado grande interesse em conhecer as dunas e lagoas que estão encantando o mundo e contribuindo para o desenvolvimento do turismo no Maranhão, aparece na tabela com 37,5\% dos entrevistados. O restante, representando a maioria dos entrevistados $-47,5 \%$, é de brasileiros de diversos estados, uma amostra que coloca os Lençóis Maranhenses como uma das principais destinações turísticas do país.

A tabela 2 apresenta um resultado onde os entrevistados, por unanimidade, responderam a pergunta sobre os motivos que os induziram a viajar para os Lençóis Maranhenses, - contemplar as belezas naturais do grande deserto brasileiro (suas dunas e lagoas). Isso quer dizer que os eventos e a fama do artesanato de Barreirinhas são apenas coadjuvantes e que a natureza é o grande produto turístico do lugar. 
. O tempo de permanência dos turistas nos Lençóis Maranhenses foi o objetivo da pergunta da tabela 3, com os seguintes resultados: até dois dias foi a resposta de $70 \%$ dos entrevistados; de dois a cinco dias 25\% e mais de cinco dias apenas 5\% dos entrevistados ficaram no local. $O$ fato de que os turistas que freqüentam os Lençóis Maranhenses são do próprio estado, a maioria, justifica uma permanência relativamente curta, considerando ainda que em dois dias é possível conhecer o PNLM e demais belezas da região.

Tabela 4 - O tipo principal de transporte utilizado pelos turistas que viajam para os Lençóis Maranhenses, conforme dados da tabela, é o automóvel - 67,5\%, de ônibus viajaram $27,5 \%$ dos turistas entrevistados e somente $5 \%$ utilizaram o avião para chegar ao PNLM. Com o fim das reformas do aeroporto de Barreirinhas que permitirá o pouso de aeronaves de grande porte, previstas para dezembro de 2003, o número de turistas que chegará de avião em Barreirinhas será muito grande, esvaziando consideravelmente o aeroporto de São Luís, hoje passagem obrigatória para os passageiros com destino aos Lençóis Maranhenses.

. Tabela 5 - Para conhecer como a mídia está divulgando os Lençóis Maranhenses como produto turístico, procurou-se saber qual era a expectativa do turista ao chegar ao local. $87,5 \%$ dos entrevistados chegaram ao local trazendo no seu imaginário um lugar mágico, de uma beleza estonteante. É assim que as empresas de turismo vendem o produto Lençóis Maranhenses. 12,5\% sabiam por meio de informações que se tratava de um bonito lugar, mas sem o exagero do marketing turístico.

. Tabela 6 - Nesta tabela buscou-se a confirmação ou não da expectativa do turista depois de conhecer os Lençóis Maranhenses e como o mesmo classificou o lugar. Para 92,5\% dos turistas trata-se de um lugar excelente, de acordo ou acima da sua expectativa; para 7,5\% trata-se de um lugar bonito, como imaginava.

.Tabela 7 - Como o turista avaliou os serviços turísticos nos Lençóis Maranhenses: Considerando os serviços turísticos como o tratamento recebido no lugar de um modo geral, $30 \%$ dos entrevistados classificaram como excelente a qualidade dos serviços recebidos na destinação turística; $52,2 \%$ consideraram que o lugar oferece um 
tratamento de boa qualidade e $17,5 \%$ responderam que os serviços oferecidos no local são apenas regulares.

Os resultados mostraram que é preciso melhorar a qualidade no atendimento ao cliente nos Lençóis Maranhenses. Isso significa que mesmo que o cliente receba um excelente tratamento por parte da comunidade local, é preciso que aconteça a mesma coisa na pousada onde o mesmo se hospedou, ou que o atendimento prestado pela empresa de turismo que o transportou para os passeios também seja de ótima qualidade e assim por diante.

Não adianta apenas um ou outro seguimento da destinação turística prestar um atendimento de ótima qualidade, é preciso que todos os atores envolvidos no processo turístico da destinação estejam imbuídos num só pensamento, - fornecer um serviço capaz de trazer o turista de volta e que o torne um dos mais positivos veículos de divulgação do lugar.

- Tabela 8 - Onde o turista se hospeda na região dos Lençóis: A maioria dos turistas entrevistados $-62,5 \%$ utilizou como hospedagem a pousada, $15 \%$ preferiu se hospedar em hotel e $22,5 \%$ ficou em casa de parentes e amigos. Por se tratar de uma cidade hospitaleira existe uma facilidade de se criar vínculos de amizade entre turistas e nativos. O turista que retorna a Barreirinhas, dependendo do tempo que passou na cidade, sempre encontra um amigo pronto para recebê-lo.

Daí o número elevado de pessoas que utiliza essa opção de hospedagem, o que prejudica um pouco o movimento das pousadas e hotéis. Entretanto, a tendência é que mesmo com a construção de hotéis na cidade, a pousada continue tendo a preferência dos turistas, por sua maior identificação com a cultura do lugar.

- Tabela 9 - O objetivo da pergunta desta tabela foi saber até que ponto os Lençóis Maranhenses já se constituem como ponto turístico independente, ou se apenas faz parte de um pacote turístico composto por destinações turísticas vizinhas como São Luís, Delta do Parnaíba e Jericoacoara. 
O resultado mostrou que $80 \%$ dos entrevistados antes de chegar aos Lençóis visitaram São Luís, 15\% conheceram antes o Delta do Parnaíba, 5\% foram direto aos Lençóis e nenhum dos entrevistados incluiu Jericoacoara no seu roteiro turístico. Os dados da tabela não deixam dúvidas de que São Luís é a principal destinação turística do Maranhão, apesar de que se costuma dizer na região dos Lençóis que São Luís é apenas uma pequena parada para os turistas com destino ao maravilhoso deserto brasileiro.

Já em São Luís se diz o contrário, em primeiro lugar o turista, especialmente o estrangeiro, conhece a "Ilha do Amor", - como é chamada a cidade de São Luís, depois ele vai conhecer os Lençóis.

Há também uma certa disputa entre Lençóis Maranhenses e Delta do Parnaíba, especialmente a parte do Delta pertencente ao Piauí.

Diante de tudo isso quem sai ganhando é o turista, pois todo mundo quer oferecer um serviço de melhor qualidade.

- Tabela 10 - Os resultados desta tabela demonstram que 40\% dos turistas quando chegam aos Lençóis Maranhenses recebem orientação sobre preservação ambiental, enquanto $60 \%$ não perceberam nenhuma preocupação dos nativos com o meio ambiente.

Esses dados são conflitantes, pois nas entrevistas com a comunidade local todos se mostraram preocupados com a preservação ambiental. No entanto, embora a amostragem seja relativamente pequena, o resultado não deixa de ser preocupante. Se $60 \%$ dos entrevistados enquanto estiveram no local não receberam nenhuma orientação sobre os cuidados que os turistas devem ter para não degradarem o meio ambiente, alguma coisa precisa ser feita.

- Tabela 11 - Nesta tabela o turista respondeu a pergunta sobre responsabilidade pela preservação ambiental nos Lençóis Maranhenses. 45\% dos entrevistados responderam que a Secretaria de Turismo e Meio Ambiente deve ser o órgão responsável pela Educação Ambiental; 25\% consideram IBAMA e 30\% dos turistas responderam que a responsabilidade é de todos, Governo, comunidade e o próprio turista. 
Infelizmente somente $30 \%$ dos entrevistados responderam que a responsabilidade pela preservação ambiental de uma destinação turística, pois o ideal seria que todos pensassem na preservação do meio ambiente como uma ação obrigatória para todos os seguimentos da sociedade.

- Tabela 12 - A pergunta desta tabela sobre a importância da cultura local como atrativo turístico foi respondida pelos turistas de forma unânime, - todos consideraram que a preservação da cultura local é fundamental para o sucesso de qualquer destinação turística.

Já vimos que o turismo provoca impactos ambientais e socioculturais negativos, muitas vezes, irreversíveis. Uma maneira de evitar que tais impactos não aconteçam é preparar todos os envolvidos no processo turístico por meio de uma Educação Ambiental permanente. 


\section{CONSIDERAÇÕES FINAIS}

Todas as projeções feitas pela OMT a respeito do Turismo apontam para um cenário cada vez mais animador, sempre na perspectiva de crescimento contínuo, geração de mais empregos e melhoria da qualidade de vida das populações residentes em pólos turísticos. Esse crescimento de acordo com a OMT deverá ocorrer nos países em desenvolvimento localizados nos continentes asiático, latino-americano, africano e médio oriental.

Em suas previsões a OMT menciona uma tendência favorável ao turismo interno nos próximos dez anos, em função do que vem sendo observado na atualidade, - um número cada vez maior de viagens de curta duração, em substituição às tradicionais viagens anuais de longa duração. Neste sentido, devem ser consideradas como viagem de curta distância as viagens regionais, típicas do turismo interno.

Quanto ao futuro do turismo no Brasil, a questão está intrinsecamente relacionada à estabilidade econômica nacional, como também dos países vizinhos que são considerados - nosso principal mercado emissor.

Entretanto, o Brasil é um país de beleza singular, com grande biodiversidade e um potencial turístico invejável em todas as suas regiões.

O Nordeste com suas lindas praias límpidas e clima quente e seco o ano inteiro; a Amazônia, a maior floresta tropical do planeta, que guarda a maior concentração de rios de água doce e volume de água do planeta, - uma riqueza em escassez no mundo inteiro; O Centro-Oeste, com uma das maiores belezas da terra, o famoso Pantanal Matogrossense, com a maior concentração de aves, peixes e répteis; o Sudeste onde o turismo já está consolidado há décadas, com destaque para o Rio de Janeiro com o seu famoso carnaval que atrai turistas do mundo inteiro, São Paulo por ser uma das maiores cidades do mundo e o maior pólo turístico do Brasil no segmento "Turismo de Negócios", e Minas Gerais, outro estado brasileiro com grande potencial turístico, com suas cidades históricas, finalmente a região Sul, pelo desenvolvimento, por está na fronteira com os países do Mercosul e também por suas belezas naturais como "as 
Cataratas do Iguaçu" O país conta ainda com um grande diferencial, a sua gente alegre e hospitaleira, o que torna o Brasil um dos países de maior potencial turístico do planeta.

No Maranhão as perspectivas para o crescimento do Turismo passam pela melhoria contínua de seus principais pólos turísticos, como São Luís, Alcântara, Carolina, Delta do Parnaíba e Lençóis Maranhenses. Essa melhoria significa um plano de ação com metas bem definidas tais como: melhoria da infra-estrutura nos pólos turísticos; capacitação profissional de todos os atores envolvidos no processo turístico em cada localidade; um programa de marketing para melhorar o sistema de divulgação do turismo no Estado, atualmente pouco divulgado e um planejamento turístico de acordo com os princípios da sustentabilidade, única forma saudável da prática das atividades turísticas.

Quanto aos Lençóis Maranhenses, ao conhecer esse maravilhoso lugar na alta temporada - janeiro de 2002, a primeira impressão que tive dessa destinação turística foi uma mistura de êxtase e preocupação. As belezas naturais do lugar, - o rio Preguiças, o mangue, os buritizais, praias, dunas, lagoas, artesanato, a calma e simplicidade da cidade de Barreirinhas e as pessoas da cidade com as quais tive contato, já iniciando o meu trabalho de pesquisa, fizeram nascer, no meu íntimo, um sentimento de pertença.

Naqueles dias pude entender porque a mídia vinha divulgando o lugar dizendo que o mesmo era de uma "beleza estonteante". Ao mesmo tempo em que fiquei em estado de êxtase, não pude conter a minha enorme preocupação pelo fato de ver tanta gente nas ruas da pequena Barreirinhas, nos restaurantes, na beira-rio, nas pousadas lotadas e pela enorme dificuldade para encontrar vaga nos transportes que faziam freneticamente os passeios para o PNLM. O movimento tanto por terra em toyota, como pelo rio em voadeira era intenso. Naqueles dias se praticava ali o temível "Turismo de Massa", onde a hipótese mais provável levantada por um pesquisador diante de tal evidência só poderia ser a iminente degradação do meio ambiente.

O objetivo do meu trabalho, a partir daquele primeiro contato, passou a ser tanto divulgar a magia dos Lençóis Maranhenses como incentivar a Educação Ambiental naquela região que inegavelmente é uma das mais belas do país, contribuindo para o desenvolvimento do turismo sustentável. 
Não se pode negar que o turismo tem o seu lado positivo como fator de desenvolvimento, geração de emprego e renda, mas ao mesmo tempo ninguém desconhece os seus impactos negativos, como degradação ambiental, destruição de cultura, expulsão dos nativos de suas terras, aumento da prostituição e elevação dos preços nas destinações turísticas.

A segunda fase desta pesquisa foi realizada no final de agosto de 2003. Um período escolhido de forma proposital, - na baixa temporada, intencionalmente para avaliar qual seria o melhor período para visitar os Lençóis Maranhenses e observar o trabalho de fiscalização e orientação, nas duas situações, executado pelo IBAMA. Pelo que observei, o melhor período para o turista conhecer os Lençóis Maranhenses é entre os meses de junho e agosto, período sem chuvas e com as lagoas cheias, exibindo "uma beleza estonteante".

Quanto à atuação do IBAMA, na alta temporada, quando o turista invade o PNLM, o trabalho de fiscalização é intensificado, a pequena equipe é reforçada para evitar uma degradação ambiental. Na baixa temporada, há um certo relaxamento.

O resultado deste trabalho de pesquisa provocou algumas reflexões que servirão como contribuição para o desenvolvimento do turismo nos Lençóis Maranhenses, um local que precisa ser preservado para as gerações futuras. Em todas as entrevistas foi possível perceber na fala dos diversos atores o amor que todos dedicam à cidade de Barreirinhas, do morador mais antigo ao mais jovem, do dono de pousada ao motorista de táxi e até mesmo o turista, todos demonstraram admiração e ao mesmo tempo a preocupação em preservar as belezas dos Lençóis Maranhenses. Para que isso aconteça algumas ações precisam ser implementadas em busca da sustentabilidade.

O primeiro e importante passo em busca do Turismo Sustentável consiste em conscientizar cada vez mais a população local, - autoridades, empresários do turismo, moradores da cidade e do campo sobre o real significado de "Meio Ambiente", que para muitos significa apenas fauna e flora, deixando de fora o mais importante dos seus componentes, - o ser humano. É importante para o morador da região dos Lençóis Maranhenses usufruir os benefícios do turismo dando a sua contribuição no tocante à preservação do meio ambiente, não jogando lixo nas ruas, no rio, nas lagoas, evitando o 
desmatamento, especialmente nas margens do rio Preguiças e contribuindo ainda na orientação dos turistas.

A cidade de Barreirinhas como qualquer outra, quer seja um pólo turístico ou não, tem os seus símbolos. A Duna do Morro da Ladeira na entrada da cidade pode ser o seu grande símbolo, apesar da Praça do Trabalhador e do rio Preguiças, porque a duna representa a essência dos Lençóis Maranhenses. Essa duna precisa ser observada nos próximos cinco anos. Seu movimento será lento e a sua preservação, como também dessa entrada da cidade, representará um marco na preservação da cultura local, mesmo que a cidade cresça desordenadamente, que se construa uma nova entrada e que as atividades turísticas proporcionem todo o modernismo a Barreirinhas, essa duna terá que ser preservada para as gerações futuras.

Os cuidados na preservação do rio Preguiças precisam ser intensificados, tendo em vista que já é visível as manchas de óleo na água onde as lanchas ancoram no cais da beira-rio. O local está ficando impróprio para banho, pois além do óleo existe uma grande quantidade de lixo jogado nas águas por pessoas que necessitam de orientação sobre higiene e educação ambiental.

Outro fator preocupante é a rede de esgoto. As autoridades responsáveis pela questão devem dispensar todos os esforços para não permitir que as residências já existentes e outras que serão construídas nas margens do rio, até mesmo complexos turísticos, despejem seus dejetos nas águas limpas do Preguiças.

A imagem é o grande marketing dos Lençóis Maranhenses. A cidade de Barreirinhas como portas dos Lençóis também necessita melhorar a sua imagem. Uma cidade limpa transmite ao turista uma sensação de bem-estar e de qualidade de vida, assim como a educação de seu povo. A prefeitura de Barreirinhas precisa atentar para uma imagem negativa da cidade, percebida e repudiada por qualquer turista, - é a grande quantidade de açougues que existe na cidade ao ar livre que atraem uma enorme quantidade de aves de rapina, - o urubu, o que representa falta de higiene e descaso com a saúde pública. 
E que ainda é de fundamental importância que a Prefeitura de Barreirinhas preserve a parceria com SENAC e SEBRAE para intensificar a qualificação profissional de todos os atores envolvidos nas atividades turísticas da região dos Lençóis Maranhenses, tendo em todos os seus programas a Educação Ambiental como tema prioritário.

Finalmente, que os turistas contemplem as belezas dos Lençóis Maranhenses com o sentimento de pertença, entendendo que esse lugar precisa ser preservado para as gerações futuras, pois se você quando ouvia falar em dunas, oásis, belezas naturais incomparáveis lembrava de outro lugar, a partir de agora tudo isso tem um significado: "Lençóis Maranhenses, um lugar mágico de uma beleza estonteante". 


\title{
BIBLIOGRAFIA
}

\begin{abstract}
ANDRADE, Rui Otávio B, (orgs). Gestão Ambiental, Enfoque EstratégicoAplicado ao Desenvolvimento Sustentável. São Paulo: Makron Books, 2000.
\end{abstract}

ARBACHE, Jorge Saba. O mercado de trabalho na atividade econômica do Turismo no Brasil. Ed. Universidade de Brasília, 2001 (p.126).

BARBOSA, Ycarim Melgaço. O Despertar do Turismo, um olhar crítico sobre os não -lugares. Série turismo, Aleph.

BENI, M. C. Análise Estrutural do Turismo. 5 ed. São Paulo: Senac, 2001.

CALISTO, Ronildo de Sousa. Lençóis Maranhenses Como Produto de Consumo. O Parque Nacional dos Lençóis Maranhenses e a utilização do seu espaço como produto turístico a partir da década de 80 . Monografia de graduação em Ciências Sociais, Universidade Federal da Paraíba, 2003.

CORREA FILHO, José de Ribamar. A importância do Turismo Sustentável nos Lençóis maranhenses (cartilha), Secretaria de Turismo e Meio Ambiente, Barreirinhas, 2002.

Curiosidades sobre Barreirinhas. www.sebraema.com.br

D’ANTONA, Álvaro de Oliveira. O Verão o Inverno e o Inverso: sobre o modo de vida de comunidades residentes na região do Parque Nacional 
dos Lençóis Maranhenses. Campinas-SP: IFCH/Unicamp. 1997 240p. (Dissertação de Mestrado em Antropologia).

DENKER, Ada de Freitas Maneti. Métodos e Técnicas de Pesquisa em Turismo. 3 ed. São Paulo: Futura, 2000.

FARIA, Dóris Santos de. Sustentabilidade Ecológica no Turismo. Dóris Santos de Faria e Kátia Saraiva Carneiro. Brasília: Editora UNB, 2001, 96p. (Coleção Gastronomia, Hotelaria e Turismo).

HALL, Stuart. A Identidade Cultural na Pós-Modernidade. Rio de Janeiro: DP\&A, 1997.

IBAMA e SEMATUR - Secretaria de Estado do Meio e Turismo do Maranhão. Diagnóstico dos Principais Problemas Ambientais do Estado do Maranhão. São Luís, 1991.

IBAMA. Unidades de Conservação do Brasil. Parques Nacionais e Reservas Biológicas. Ministério do Interior, Brasília: 1989. p 182.

IGNARRA, Luiz Renato. Fundamentos do Turismo, São Paulo: Pioneira, 2001.

LEFF, Enrique. Saber ambiental: sustentabilidade, racionalidade, complexidade, poder. Enrique Leff; tradução de Lúcia Mathilde Endlich Orth, Petrópoles: Vozes, 2001. 
MACHADO, Maria Salete K. O Imaginário Urbano, in Palavras da Cidade. BRESCHIANI, M. S. (0rg), Porto Alegre: Ed. UFRS, 2001/págs. 213 a 226.

Ministério do Esporte e Turismo/EMBRATUR - Instituto Brasileiro do Turismo. Principais Evoluções: 1995 / 2002.

Ministério do Meio Ambiente. SNUC. Sistema Nacional de Unidades de Conservação da Natureza.

MODERNELL, Renato. Lençóis, dunas e lagoas maranhenses que encantam todo mundo. Terra, p. 42/53, setembro/2002.

PORTER, Michael. Clusters e Competitividade, agosto/1999.

RAMALHO, Cristina. Dossiê Maranhão; Lençóis, São Luís, Alcântara, Delta do Parnaíba. Revista Viagem, p.48/59, ano 9, n. 2, fevereiro/ 2003.

RUSCHANN, D. v.d. M. “Turismo Sustentado para a Preservação do Patrimônio Ambiental", em Turismo em Análise. São Paulo: v 3 n.1, 1993.

SANTOS, Cínthia Saldanha Braga Nogueira. Uma abordagem sobre os serviços hoteleiros oferecidos em Barreirinhas - Maranhão. Monografia apresentada ao Curso de Especialização em Gestão da Hospitalidade, Universidade de Brasília, 2003.

SENAC - Educação Ambiental. Ano $11 \mathrm{n}^{\circ}$ 3, Ecoturismo: Solução ou Problema? Setembro/dezembro, 2002. 
SENAC. DN. Turismo: Espaço e Tempo, Miguel Farah Neto; Neise Freitas da Silva; Márcia Capella. Ed: Senac Nacional, Rio de Janeiro, 2000, (84 p.)

SERRANO, C. e outros (2000). Olhares contemporâneos sobre o Turismo. Ed. Papirus, Campinas. Turismo e Hospitalaidade Representações e Fenômenos mediáticos.

THEOBALD, William F, (org). Turismo Global. 2. ed. São Paulo. Ed: SENAC - São Paulo, 2002.

TRIGO, Luiz Gonzaga Godoi (org), Turismo, Como Aprender, Como Ensinar, v. 1 e 2, 2. ed, São Paulo: SENAC, 2001.

Turismo e Paisagem / Eduardo Yázigi, (org.). - São Paulo: Contexto, 2002.

VAZ, Gil Nuno. Marketing Turístico, São Paulo: Pioneira, 1999.

WILliAM, R. O campo e a cidade. São Paulo: Cia das Letras, 1989 (pág. 11 a 20).

YÁZIGI, Eduardo - A Alma do Lugar. Turismo, Planejamento e Cotidiano. São Paulo: Contexto, 2001. 
ANEXOS 


\section{ANEXO A - IMAGENS}

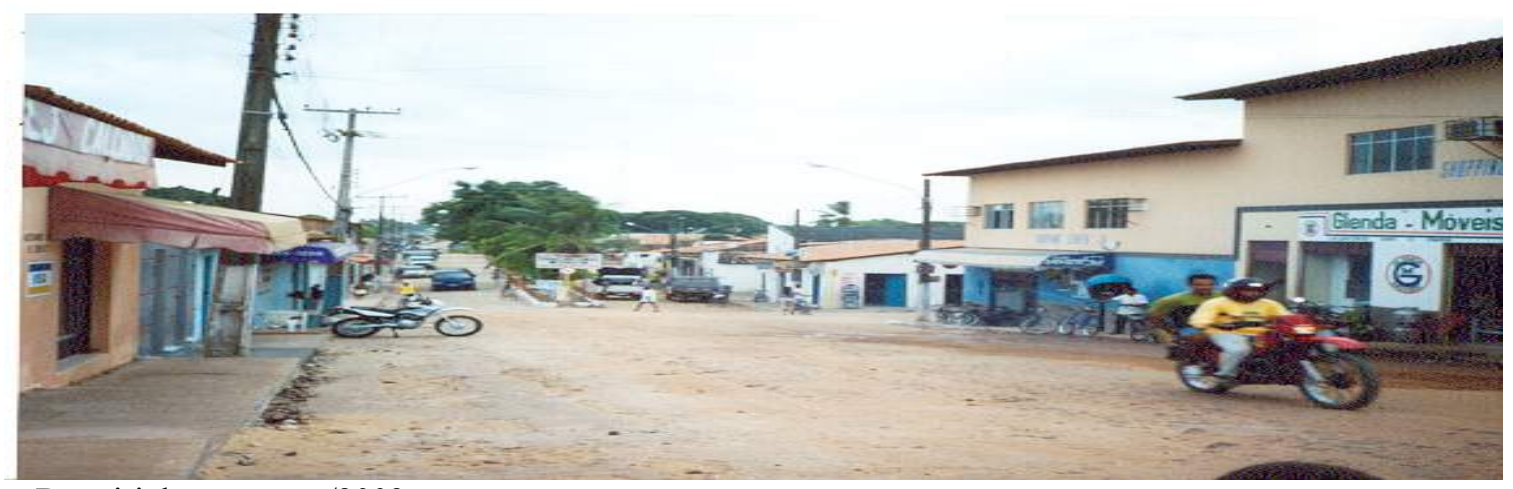

Barreirinhas - agosto/2003

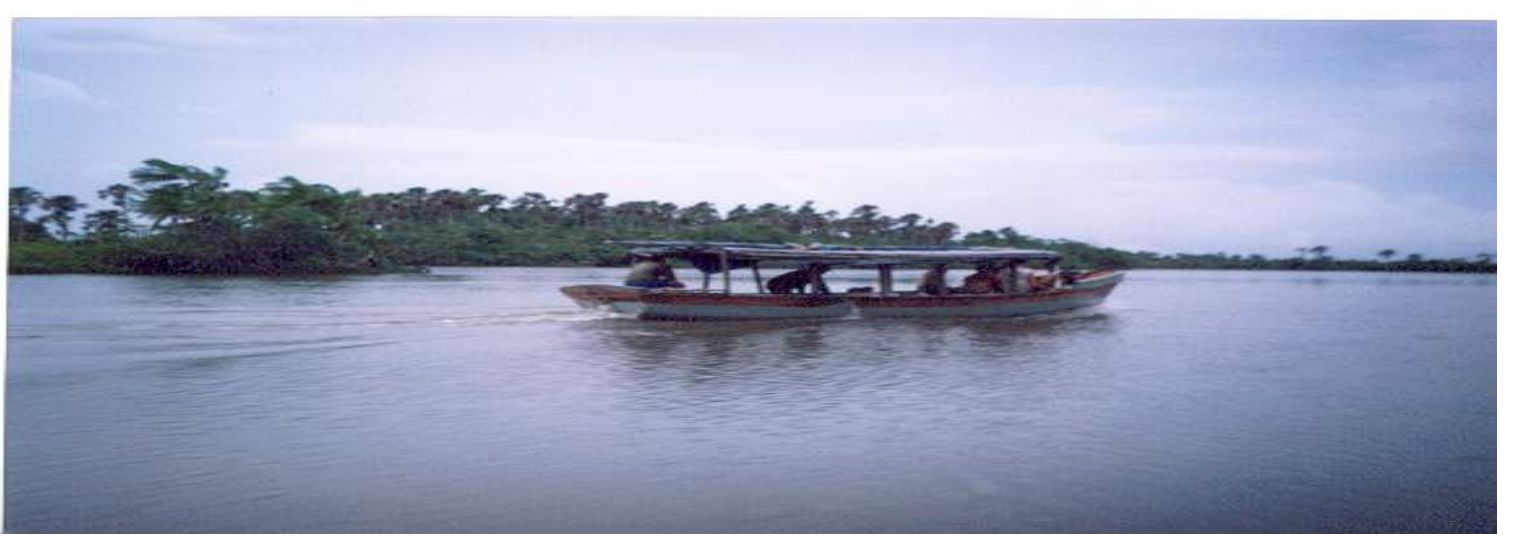

Preguiças - tipo de embarcação dos nativos (agosto/2003
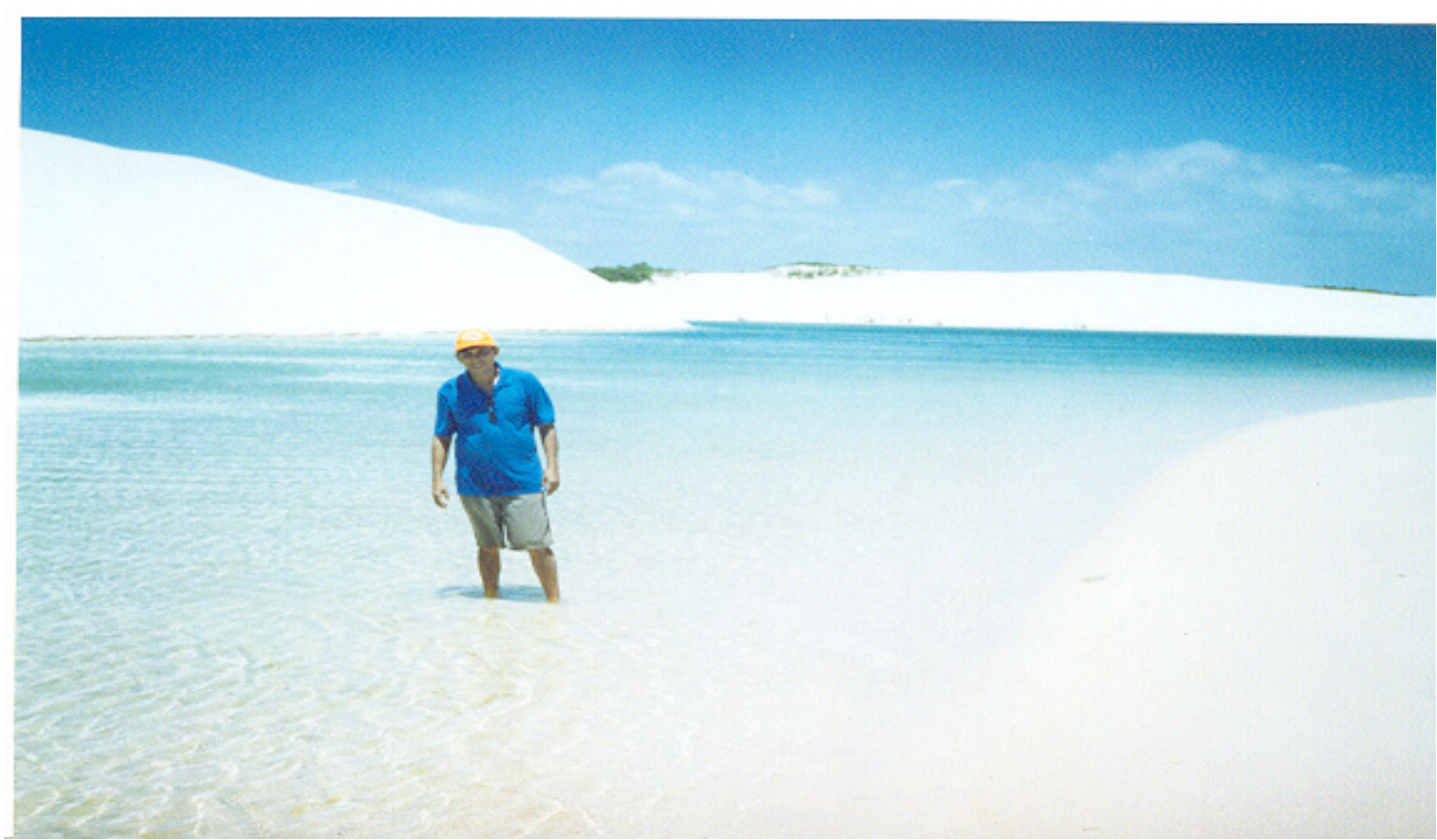

Lagoa Azul (agosto de 2003) - A lagoa mais visitada dos Lençóis Maranhenses. 


\section{ANEXO B}

\section{Curiosidades sobre os Lençóis Maranhenses:}

. A área de extensão do município de Barreirinhas é de $2.477 \mathrm{~km}^{2}$;

- Atividades econômicas de Barreirinhas: Extração da castanha de caju, Artesanato da fibra do buriti, Pesca, Farinha de mandioca e Turismo.

. O farol de mandacaru tem 45 metros de altura e 160 degraus;

. A duma mais alta dos Lençóis se chama Catedral, - próxima de Atins;

. Os Lençóis Maranhenses possuem praias de até 80 quilômetros;

. Os Lençóis Maranhenses estão divididos em duas partes: Pequenos Lençóis (Área de Proteção Ambiental - APA) Grandes Lençóis - Parque Nacional;

. O Parque Nacional dos Lençóis Maranhenses tem uma área de 155.000 hectares, maior que a grande São Paulo;

- Apesar dos ares desérticos os Lençóis possuem uma vasta diversidade biológica, uma rica fauna microscópica que cumpre o papel fundamental na alimentação e reprodução de diversas aves migratórias e animais ameaçados de extinção. (SEBRAE - www.sebraema.com.br). 


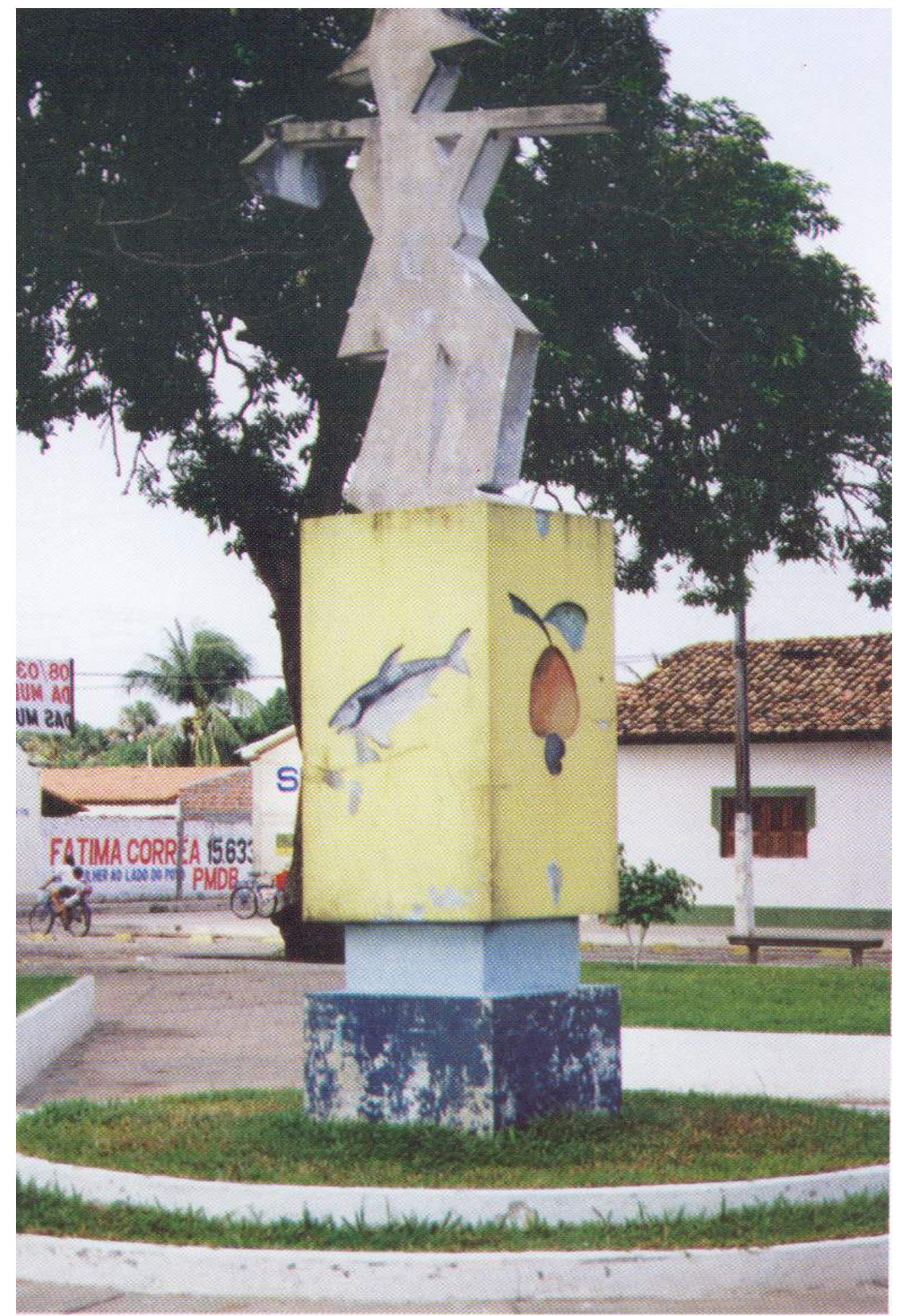

Praça do Trabalhador (IBAMA - 2002) - Este monumento é uma homenagem ao trabalhador e representa em cada lado as riquezas da região: o caju, o peixe a mandioca e a palmeira de buriti. 


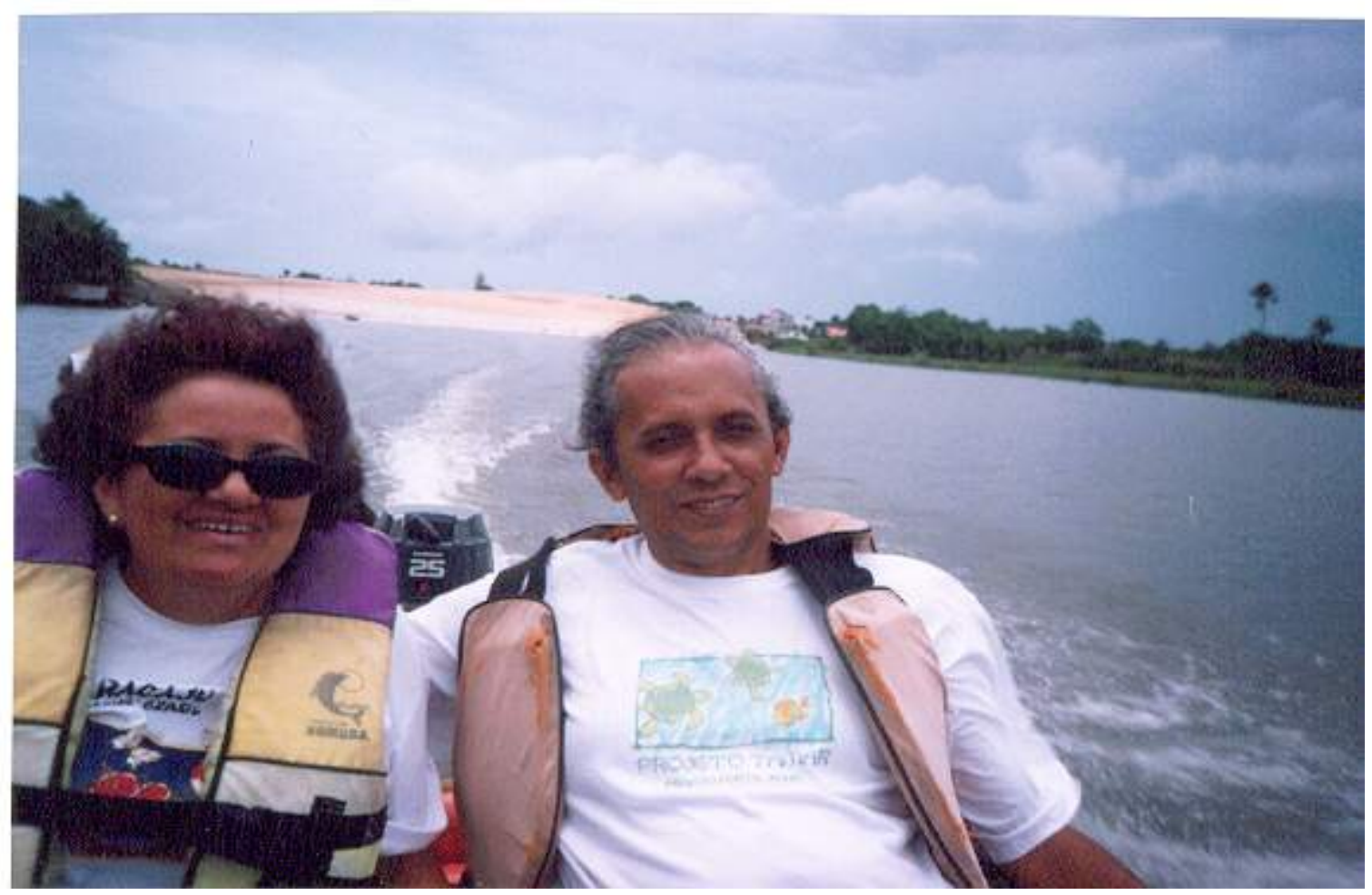

Passeio de voadeira (janeiro de 2002) - rio Preguiças

Pousada do Paulo - Caburé (agosto de 2003)

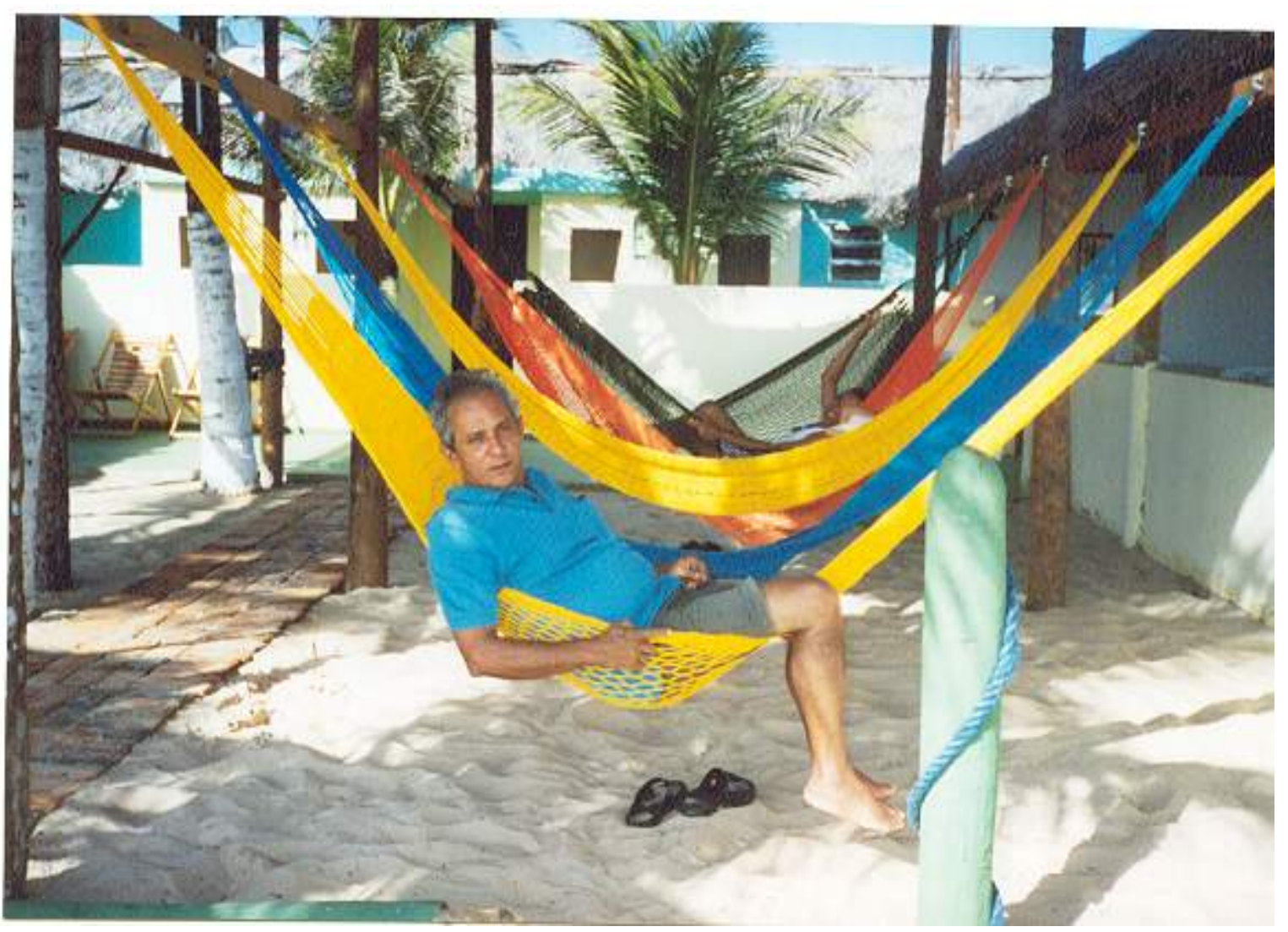

